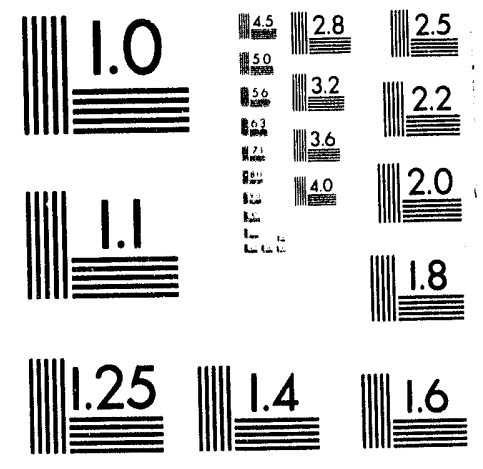



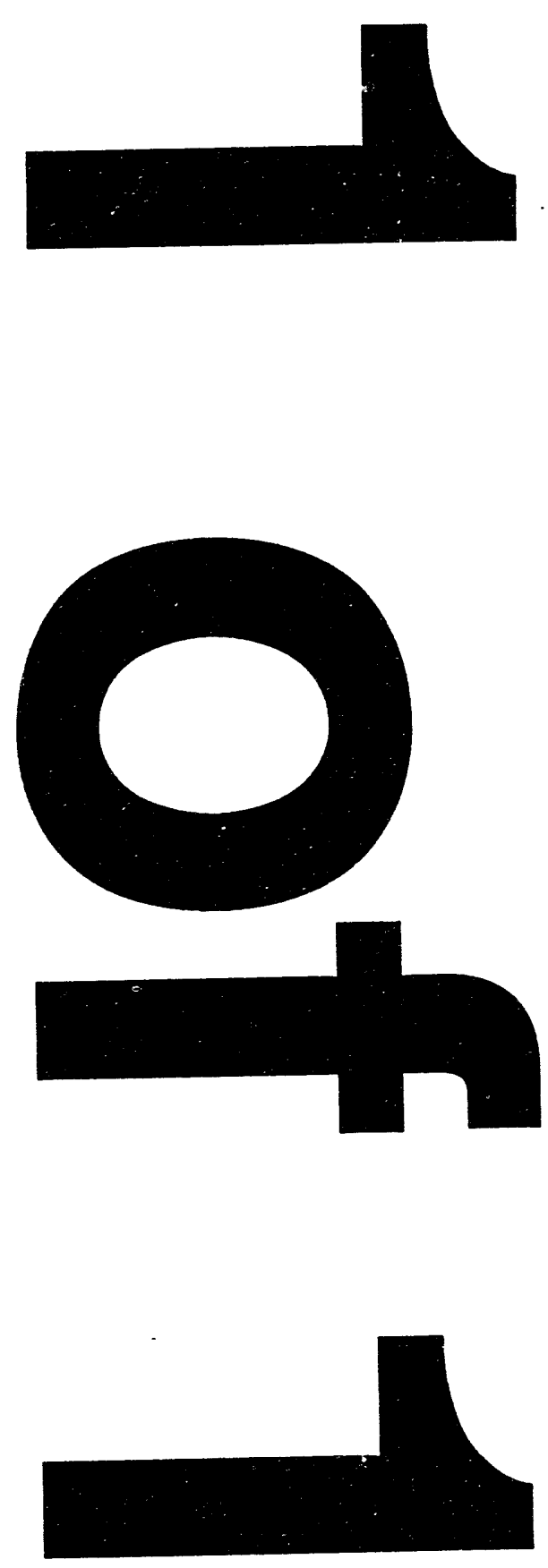


\section{DOE/mC/ $11089-3694$}

\section{PRESSURIZED FLUIDIZED-BED HYDRORETORTING OF EASTERN OIL SHALES}

Progress Report for the Period July-September 1989
By
D. V. Punwani
F.S. Lau
T. M. Knowlton
C. Akin
M. J. Roberts
J. G. Findlay
A. Maka
J. Abbasian
T. Y. Xiong
D. M. Rue

M. C. Mensinger

December 1989

Work Performed Under Contract No.: DE-AC21-87MC11089

\section{For}

U.S. Department of Energy

Office of Fossil Energy

Morgantown Energy Technology Center

Morgantown, West Virginia 26505

By

Institute of Gas Technology

Chicago, Illinois 60616

TECHNICAL INFORMATION CENTER

OFFICE OF SCIENTIFIC AND TECHNICAL INFORMATION UNITED STATES DEPARTMENT OF ENERGY 


\title{
PRESSURIZED FLUIDIZED-BED HYDRORETORTING OF EASTERN OIL SHALES
}

Progress Report for the Period July-September 1989

\author{
By \\ D. V. Punwani \\ F. S. Lau \\ T. M. Knowiton \\ C. Akin \\ M. J. Roberts \\ J. G. Findlay \\ M. C. Mensinger \\ J. Abbasian \\ A. Maka \\ T. Y. Xiong \\ D. M. Rue
}

December 1989

Work Performed Under Contract No.: DE-AC21-87MC11089

\section{For}

U.S. Department of Energy

Office of Fossil Energy

Morgantown Energy Technology Center

P.O. Box 880

Morgantown, West Virginia 26505

By

Institute of Gas Technology

IIT Center, 3424 S. State Street

Chicago, Illinois 60616 


\section{DISCLAIMER}

This report was prepared as an account of work sponsored by an agency of the United States government. Neither the United States Government nor any agency thereof, nor any of their employees, makes any warranty, express or implied, or assumes any legal liability or responsibility for the accuracy, completeness, or usefuiness of any information, apparatus, product, or process disclosed, or represents that its use wou!d not infringe privately owned rights. Reference herein to any specific commercial product, process, or service by trade name, trademark, manufacturer, or otherwise, does not necessarily constitute or imply its endorsement, recommendation, or favoring by the United States Government or any agency thereof. The views and opinions of authors expressed herein do not necessarily state or reflect those of the United States Government or any agency thereof.

Printed in the United States of America

Available from

National Technical Information Service

U.S. Department of Commerce

5285 Port Royal Road

Springfield, VA 22161

NTIS price codes

Printed copy: A05

Microfiche copy: A01 


\section{EXECUTIVE SUMMARY}

This report presents the work performed during the eighth program quarter from July 1 through September 30, 1989, under U.S. Department of Energy (DOE) Contract No. DE-AC21-87MC11089 for the project "Pressurized Fluidized-Bed Hydroretorting (PFH) of Eastern Oil Shales." The Institute of Gas Technology ( $\left(\mathrm{GT}^{\circ}\right.$ ) is the prime contractor for the overall program. Seven universities are working with IGT as subcontractors; their responsibilities and achievements in the program are discussed below in the appropriate tasks.

In Task 1 (PFH Scoping Studies), 8 batch PFH tests were conducted with Indiana New Albany shale to repeat several earlier tests, to determine the effects of particle size on oil yield and carbon conversion, and to study the effect of no shale preheat at a pressure of $600 \mathrm{psig}$. The results show that the carbon conversions to oil and gas are not affected by particle size within the ranges studied $(-200+270,-100+140$, and $-60+100 \mathrm{mesh})$. The results also show that preheat temperature and residence times in the ranges of $75^{\circ}$ to $600^{\circ} \mathrm{F}$ and 15 to 30 minutes, respectively, do not significantly affect the yields of oil or hydrocarbon gases.

Tests were also conducted in the batch $\mathrm{PFH}$ reactor at residence times as short as 4 minutes at $900^{\circ} \mathrm{F}$ and pressures of 600 and 1000 psig to determine the effect on oil and gas yields. Reducing the residence time from 20 to 4 minutes did not appear to have any effect on the oil yield, however, the carbon conversion to gas decreased somewhat.

In Subtask 1.2, one successful test was conducted in the continuous PFH unit at a temperature of $900^{\circ} \mathrm{F}$, hydrogen pressure of $400 \mathrm{psig}$ with $-60+100$ mesh Indiana shale. The average shale residence time was 36 minutes. The carbon conversions to oil and gas achieved in this test were 618 and 48 , respectively. Batch tests at the same conditions had average carbon conversions to oil and gas of 548 and 108 .

In Subtask 2.1 (Lab-Scale Batch Tests), 4 successful tests were conducted in the batch $\mathrm{PFH}$ unit to repeat earlier tests that showed inconsistent results when compared with the entire data base. The results of these tests will be reported when laboratory analyses are completed. Tests planned to be conducted in this Subtask have been completed.

In Subtask 2.2 (Lab-Scale Continuous Tests), 3 successful tests were conducted in the continuous PFH reactor with Alabama Chattanooga, Kentucky New Albany, and Ohio Cleveland shales at $900^{\circ} \mathrm{F}$ and a hydrogen pressure of 600 psig. The results will be presented when the product analyses have been completed.

In Subtask 2.3 (Bench-Scale Tests), equipment modifications continued on the high-pressure reactor. The product gas heat exchanger and the data acquisition hardware and software were ordered during the quarter.

IGT continued work on Subtask 2.4 (Data Analysis and Correlations) during the quarter, providing correlations for oil and gas yields based on 
batch and continuous $\mathrm{PFH}$ test results for inclusion in the computer program that simulates the PFH process.

In Subtask 3.1 (In-Bed Sulfur Capture Tests), 1 test was conducted to determine the effectiveness of calcined limestone as a material for PFH in-bed sulfur capture. The test was conducted at $1050^{\circ} \mathrm{F}$ and $600 \mathrm{psig}$ with a residence time of 3 minutes. A sufficient quantity of calcined limestone was initially added to the Indiana feed shale to provide 1.5 moles of calcium per mole of feed sulfur. The results showed that the addition of limestone reduced the sulfur conversion from the expected 508 to 9.38 . The presence of the calcined limestone did not alter the sulfur content of the shale oil or the conversion of sulfur to oil.

In Subtask 3.2 (Electrostatic Desulfurization), the Illinois Institute of Technology developed a simple model to describe the batch electrostatic separator, based on the design theory for 2-stage electrostatic precipitators. The kerogen concentrations predicted by the model were higher than those obtained experimentally, however the predicted trend was similar. Work is in progress to refine the model and experimental apparatus.

In Subtask 3.3.1 (Microbial Desulfurization and Denitrification), Ohio State University (OSU), isolated 16 cultures from a sample of Meigs Creek No. 9 bituminous coal. The cultures will be screened for their ability to metabolize sulfur and nitrogen from shale.

In Subtask 3.3.2 (Microbial Process Development), IGT conducted a desulfurization test with a mixed culture of organisms. After 14 days of incubation in the presence of shale as the sole sulfur source, a 198 sulfur reduction was achieved. It is not clear if the sulfur reduction was due to a single microorganism or if a consortium was responsible.

The University of Alabama Mineral Resources Institute (MRI) is responsible for the wrrk being conducted in Task 4 (Beneficiation Research).

In Subtask 4.1 .2 (Pressure Cycling Comminution), the University of Nevada (Reno) initiated tests in the pressure cycling comminution (PCC) apparatus with Indiana shaie at confining pressures up to 5000 psig. Preliminary results show that PCC increases surficial breakage and improves subsequent grinding of the treated sample. The results of PCC tests conducted with samples of shale pretreated with hardness reducers, also showed favorable improvements in grindability.

In Subtask 4.1.3 (Stirred Ball Mill Grinding), MRI conducted several series of tests in the Netzsch mill with samples of -100 mesh Indiana shale. The objective of these tests was to determine the effects of media loading, solids concentration in the slurry, and rotor speed on the grinding characteristics of the shale. The results show that at 808 media loading, a slurry concentration of 40 to 50 wt 8 solids, and a feed rate of about $300 \mathrm{~mL} / \mathrm{min}$, the mill must be operated at high rotor speed (1500 rpm) to achieve the desired consist ( $<10$ microns) in a single pass. 
In Subtask 4.1 .4 (Grinding Circuit Optimization), MRI built and began testing a stainless steel batch ball mill, equipped with a variable speed drive and ammeter recorder assembly for measuring current used while grinding. Preliminary wet grinding tests were conducted using - 10 mesh Indiana shale at 40 wt solids. The results are not yet avallable.

In Subtask 4.2.1 (Column Flotation Tests), MRI conducted tests in a variable-height column with Alabama shale ground to 908 less than 12:4 microns. The effects of column height, waste water rate, feed inlet position, and air sparger pore size were measured. The data show that column height is the dominant parameter.

MRI also conducted tests with samples of Kentucky, Michigan, Ohio, and Tennessee shales to compare the performance of column and mechanical flotation cells. The samples were prepared using a standardized grinding procedure that also indicates relative grindability. Flotation was done at approximately 10 wt $z$ solids in the rougher stage with a frother dose of $1.6 \mathrm{lb} /$ ton. The results show that in all cases (except Kentucky shale) superior results were obtained with the column cell. The data also show that the Michigan shale responded best to flotation and the Ohio shale, even though it was the most finely ground, responded worst. These data show that the liberation characteristics of the 4 shales tested are significantly different. Further optimization of column cell parameters for each specific shal is required.

Because none of the results achieved to date have been encouraging, MRI has discontinued work on Subtask 4.2.2 (Air-Sparged Hydrocyclone).

In Subtask 4.2.3 (LICADO Process), the University of Pittsburgh conducted tests in the batch research unit and in the 4-inch continuous research development unit (RDU). The objectives of these tests were to determine the effects of dispersant ( 1 - and 2-octanol) concentration and operating conditions on oil yield and recovery. The results show that significant improvements can be achieved in product Fischer Assay if the dispersant concentration is in excess of $300 \mathrm{ppm}$. Fischer Assays as high as 30 gallons/ton with oil yields of 708 were obtained with $500 \mathrm{ppm} 1$-octanol. 011 recoveries in excess of 708 could be obtained in the batch unit by using the appropriate dose of reagent. Additional tests will be conducted at different particle sizes of feed shale to optimize process performance.

UP also conducted preliminary tests in the RDU using a premixing time of 7 minutes, slurry concentrations of 2 to 3 wt 8 solids, liquid $\mathrm{CO}_{2}$ flow rate of $500 \mathrm{~mL} / \mathrm{min}$, and a contact time of 15 minutes. The results show that with 1-octanol, significant improvement in the oil recovery (63.38) was obtained at a mixing speed of $2050 \mathrm{rpm}$. However, this was accompanied by a decrease in the Fischer Assay of the product, suggesting that mineral matter was being entrapped in the agglomerates of the upgraded material with liquid $\mathrm{CO}_{2}$.

In Subtask 4.3 (Waste Treatment and Disposal Studies), MRI ground samples of the 6 shales in deionized water ( 35 wt 8 solids) for 30 minutes, and then filtered the slurries without dilution to obtain water samples for analyses. These diluted water samples are being processed through an activated charcoal, anionic and cationic resin system to study the removal of total 
organic carbon compounds and trace and minor elements that may be considered hazardous to the environment.

In Task 5 (Operation of PFH on Beneficiated Shale), IGT conducted a fluidization test with a portion of the bulk sample of beneficiated Indiana shale received from MRI last quarter. The fluidization characteristics of this material are very similar to those of the original sample. Evaluation of various methods to feed the beneficiated shale into a high-pressure reactor continued during the quarter.

In Subtask 6.1 (Characterization of Processed Shales), IGT submitted 4 samples of spent shales to be analyzed for physical properties. The equipment needed for preparing agglomerated and slagged samples for leaching tests was checked for operability.

In Subtask 6.2 (Water Availability and Treatment Studies), Tennessee Technological University (TTU) conducted aerobic biological treatment tests with the 4 compounds with acclimated cultures. The aerobic treatment reduced the chemical oxygen demand of the $\mathrm{PFH}$ synthetic wastewater from $900 \mathrm{mg} \mathrm{O}_{2} / \mathrm{L}$ to about $25 \mathrm{mg} \mathrm{O}_{2} / \mathrm{L}$ after 160 hours. In Subtask 6.4.2 (Environmental Impacts), TTU continued obtaining information about the applicable laws and environmental impacts of the $\mathrm{PFH}$ process for comparison with conventional thermal retorting.

In Subtask 6.3 (Heavy Metals Remova1), the University of Michigan conducted barium dissolution tests with hydrochloric acid and sodium chloride ( $\mathrm{NaCl}$ as the catalyst) on samples of spent Indiana shale. The results showed that the presence of $\mathrm{NaCl}$ increased the rate of barium dissolution by 7.6 times compared to the uncatalyzed case.

In Subtask 6.4 (PFH Systems Analyses), IGT incorporated correlations for oil and gas yields based on the results of batch and continuous PFH tests into the computer program that simulates the overall PFH process.

In Task 8 (Project Management and Reporting), IGT continued to monitor the progress and activities of the participants and subcontractors in the program. 


\section{TABLE OF CONTENTS}

Page

INTRODUCTION

ACHIEVEMENTS $\quad 2$

Task 1. PFH Scoping Studies 2

Task 2. PFH Optimization Tests 15

Task 3. Testing of Process Improvement Concepts 18

Task 4. Beneficiation Research 26

Task 5. Operation of PFH on Beneficiated Shale 48

Task 6. Environmental Data and Mitigation Analyses 48

Task 7. Sample Procurement, Preparation, and Characterization 81

Task 8. Project Management and Reporting 81

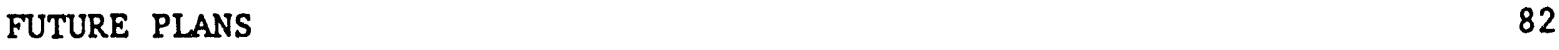

$\begin{array}{lc}\text { ACKNOWLEDGMENTS } & 82\end{array}$

$\begin{array}{ll}\text { REFERENCES } & 82\end{array}$ 


\section{LIST OF FIGURES}

Figure No.

Page

1-1 The Effect of Preheat Temperature on Feed Carbon Conversion to 011

1-2 The Effect of Preheat Temperature on Feed Carbon Conversion to Gas

1-3 The Effect of Particle Size on Feed Carbon Conversion

1-4 The Effect of Hydrogen Pressure on Feed Carbon Conversion at $1050^{\circ} \mathrm{F}$

1-5 The Effect of Hydrogen Pressure on Feed Carbon Conversion at $900^{\circ} \mathrm{F}$

1.6 The Effect of Hydroretorting Temperature on Feed Carbnn Conversion at 600 psig Hydrogen Pressure

1.7 The Effect of Hydroretorting Temperature on Feed Carbon Conversion at 1000 psig Hydrogen Pressure

2-1 Schematic Diagram of Equipment Layout

3-1 Comparison of the Experimentally Obtained Data From the Batch Separator With Those Predicted by the Model

4-1 MRI Stirred Ball Mill Grinding Setup 30

4-2 Conventional MRI Ball Mill Setup 32

4-3 Cumulative Breakage Function $\left(B_{i j}\right)$ Versus Particle Size Estimated by MRIEST for Wet Grinding of Indiana Shale

4-4 Specific Selection Function ( $\mathrm{Si}^{\mathrm{E}}$ ) Versus Particle Size ( $x$ ) Provided by MRIEST Fit for Wet (408)

Grinding of Indiana Shale

4-5 Comparison of Experimental Product Size Distributions and Linear Model Fit for Wet Grinding of Indiana Shale

4-6 Comparison of Grade Recovery Curves for Column Ce11 and Mechanical Cell Flotation for Kentucky Oil Shale

4-7 Comparison of Grade Recovery Curves for Column Cell and Mechanical Cell Flotation for Ohio Oil Shale 
4-8 Comparison of Grade Recovery Curves for Column Cell and Mechanical Cell Flotation for Michigan Oil Shale

4-9 Comparison of Grade Recovery Curves for Column Cell and Mechanical Cell Flotation for Tennessee Oil Shale 40

4-10 Effect of 1-Octanol for Indiana Oil Shale 42

4-11 Effect of 2-Octanol for Indiana Oil Shale 43

4-12 Research Development Unit (RDU) 45

6-1 Biological Removal of Two Substrates ( $300 \mathrm{mg} / \mathrm{L}$ Propionitrile and $\mathrm{SCN}^{-}$Initially)

6-2 Biological Removal of Two Substrates ( $300 \mathrm{mg} / \mathrm{L}$ Propionitrile and $\mathrm{SCN}^{-}$Initially): Log Plot

6-3 Biological Removal of Two Substrates ( $300 \mathrm{mg} / \mathrm{L}$ Pyrrole and $\mathrm{SCN}^{-}$Initially)

6-4 Biological Removal of Two Substrates ( $300 \mathrm{mg} / \mathrm{L}$ Pyrrole and $\mathrm{SCN}^{-}$Initially): Log Plot

6-5 Biological Removal of Four Substrates (150 mg/L Each of Acetone, Propionitrile, Pyrrole and $\mathrm{SCN}^{-}$ Initially)

6-6 Biological Removal of Four Substrates (150 mg/L Each of Acetone, Propionitrile, Pyrrole and $\mathrm{SCN}^{-}$ Initially): Log Plot

Continuous Flow Results (Hydraulic Retention Time of 5 Days)

6-8 Removal of Four Substrates by Biological Treatment

6-9 Removal of Four Substrates by Biological Treatment: Log Plot

6-10 Exhaustion Curve for the Adsorption of Acetone From Aqueous Multisolute Solution onto F-300 Activated Carbon

6-11 Exhaustion Curve for the Adsorption of Propionitrile From Aqueous Multisolute Solution onto F-300 Activated Carbon 
LIST OF FIGURES, Cont.

Figure No,

Page

6-12 Thiocyanate Adsorption: Freundlich Isotherm for

Filtrasorb 300 (Thiocyanate Range: $5-100 \mathrm{mg} / \mathrm{L}$ )

64

6-13 Acetone Adsorption: Freundlich Isotherm for

Filtrasorb 300 (Acetone Range: 5-100 mg/L)

6-14 Pyrrole Adsorption: Freundlich Isotherm for

Filtrasorb 300 (Pyrrole Range: 5-100 mg/L)

6-15 Propionitrile Adsorption: Freundlich Isotherm for Filtrasorb 300 (Propionitrile Range: 5-100 mg/L)

6-16 Thiocyanate Adsorption: Equilibrium Experiment for Filtrasorb 300

6-17 Acetone Adsorption: Equilibrium Experiment for Filtrasorb 300

6-18 Pyrrole Adsorption: Equilibrium Experiment for Filtrasorb 300

6-19 Propionitrile Adsorption: Equilibrium Experiment for Filtrasorb 300

6-20 Barium Dissolution in $\mathrm{HCl} / \mathrm{NaCl}$

6-21 Barium Dissolution in Brine 73

6-22 CdS Dissolution in HI (Parts a, b, and c) 75

6-23 CdS Dissolution in Nitric Acid 76 


\section{LIST OF TABLES}

Table No.

Page

1-1 Summary of Test Conditions and Results of Batch PFH Tests With Indiana New Albany Shale

1-2 Sunmary of Test Conditions and Results of PFH Continuous Tests $w^{4}$.th Indiana New Albany Shale

1-3 Sulfur Balances For Indiana New Albany Shale Continuous PFH Tests

$2-1$

Summary of Test Conditions For Batch PFH Tests

2-2 Summary of Test Conditions For Continuous PFH Tests

3-1 Sulfur Conversions Achieved in Batch PFH

Tests With Indiana New Albany Shale

4-1 The Effects of Operating Conditions on the Results of Tests Conducted in the Stirred Ball Mill With Indiana Shale

Conventional MRI Ball Mill Details

6-1 Adsorption of $\mathrm{SCN}^{-}$, Acetone, Pyrrole, and Propionitrile by Filtrasorb 300 Powdered Activated Carbon on Indiana New Albany Shale Samples 


\section{INTRODUCTION}

The Devonian ofl shales of the Eastern United States are a significant domestic energy resource. The overall objective of the 3-year program, initiated in October 1987 by the U.S. Department of Energy (DOE) (Contract No. DE-AC21-87MC11089), is to perform the research necessary to develop the pressurized fluidized-bed hydroretorting (PFH) process for producing oil from Eastern oil shales. The program also incorporates research on technologies in areas such as raw shale preparation, beneficiation, product separation, and waste disposal that have the potential of improving the economics and/or environmental acceptability of recovering oil from oil shales using the PFH process. The program is divided into the following eight tasks:

Task 1. PFH Scoping Studies

Task 2. PFH Optimization Tests

Task 3. Testing of Process Improvement Concepts

Task 4. Beneficiation Research

Task 5. Operation of PFH on Beneficiated Shale

Task 6. Environmental Data and Mitigation Analyses

Task 7. Sample Procurement, Preparation, and Characterization

Task 8. Project Management and Reporting.

In order to accomplish all the program objectives, the Institute of Gas Technology (IGT), the prime contractor, is working with seven other institutions; the University of Alabama/Mineral Resources Institute (MRI), Illinois Institute of Technology (IIT), the University of Michigan (UM), the University of Nevada (UN), Ohio State University (OSU), Tennessee Technological University (TTU) and the University of Pittsburgh (UP).

This report presents the work performed during the eighth program quarter from July 1 through September 30, 1989. 


\section{ACHIEVEMENTS}

\section{Task 1. PFH Scoping Studies}

The objective of this task is to determine the effects of process variables on product yields. The results of these tests will be used in Task 2 (PFH optimization tests). This task is divided into two subtasks: Batch Tests and Continuous Tests.

\section{Subtask 1.1. Batch Tests}

The objective of this task is to construct and operate a laboratoryscale batch test unit to determine the effects of a number of independent variables that may affect the product yields of the PFH process.

\section{Discussion}

Eight batch PFH tests (Tests 87 and 89 through 95) were conducted this quarter with Indiana New Albany shale. The shale used for these tests was from the same batch of Indiana used in earlier tests. The shale moisture content was 2.07 wt 8 , and the carbon, hydrogen, and ash contents (dry basis) were $14.72,1.66$, and $78.16 \mathrm{wt} 8$, respectively. A summary of the operating conditions and results of the tests are presented in Table 1-1. Operating conditions include the preheater and reactor temperatures and residence times, reactor pressure, and the superficial gas velocity in the reactor. The minimum fluidization velocity for the smallest feed shale particles is also included. The results include reconciled product carbon distributions and oil yields, the oil specific gravities, and the product gas compositions.

Carbon balances were reconciled by adjusting the amounts of carbon to gas and oil by the same factor. The amount of carbon found in the residue shale and the ratio of carbon in oil to carbon in the gas were assumed to be correct. Unreconciled carbon balances for the 8 tests conducted this quarter ranged from 82.08 to 96.58 .

The operating conditions were selected based on the results of earlier tests. The objectives of the tests were to repeat several earlier tests, to study the effects of particle size on oil yield and carbon conversion, and to study the effect of no shale preheat at a pressure of 600 psig. The results have been incorporated into the PFH data base for Indiana shale.

The results of these tests show that the preheat temperature in the range of $75^{\circ}$ to $600^{\circ} \mathrm{F}$ and residence times in the range of 15 to 30 minutes do not significantly affect the yields of oil or hydrocarbon gases (Figure 1-1). The preheat conditions do not affect oil yield when subsequently retorted at reactor conditions of $900^{\circ} \mathrm{F}$ and 600 psig or $1050^{\circ} \mathrm{F}$ and 1000 psig. Similarly, Figure 1-2 shows that there also does not appear to be any affect of preheat conditions on the conversion of shale carbon to gas for $\mathrm{PFH}$ tests at $1050^{\circ} \mathrm{F}$ and 1000 psig. The conversions of feed shale carbon to oil and gas were, therefore, unaffected by the various preheat conditions studied. 
Table 1-1. SUMMARY OF TEST CONDITIONS AND RESULTS OF BATCH PFH TESTS WITH INDIANA NEW ALBANY SHALE

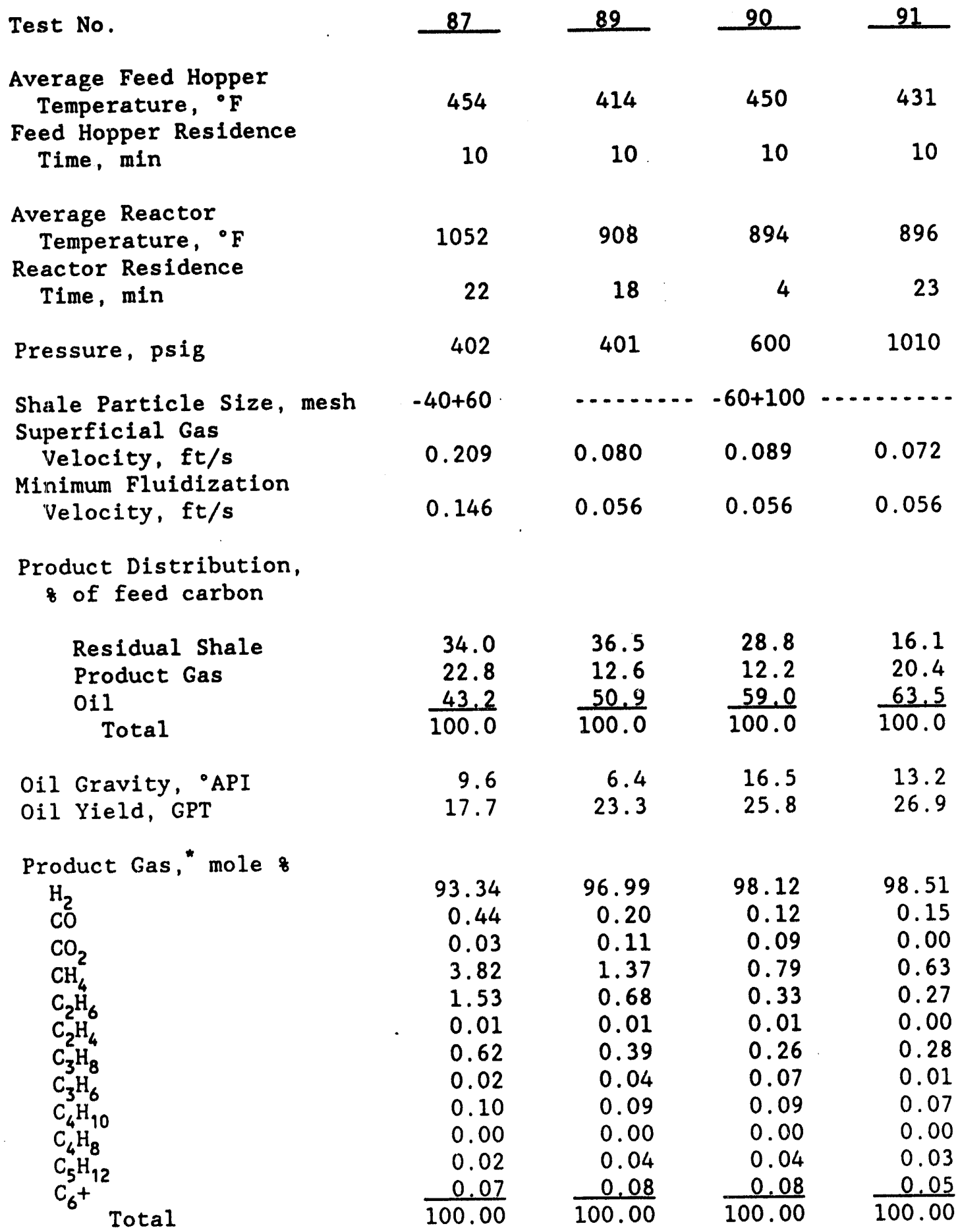

* $\mathrm{H}_{2} \mathrm{~S}$-free basis. 
Table 1-1 (Cont.). SUMMARY OF TEST CONDITIONS AND RESULTS OF BATCH PFH TESTS WITH INDIANA NEW ALBANY SHALE

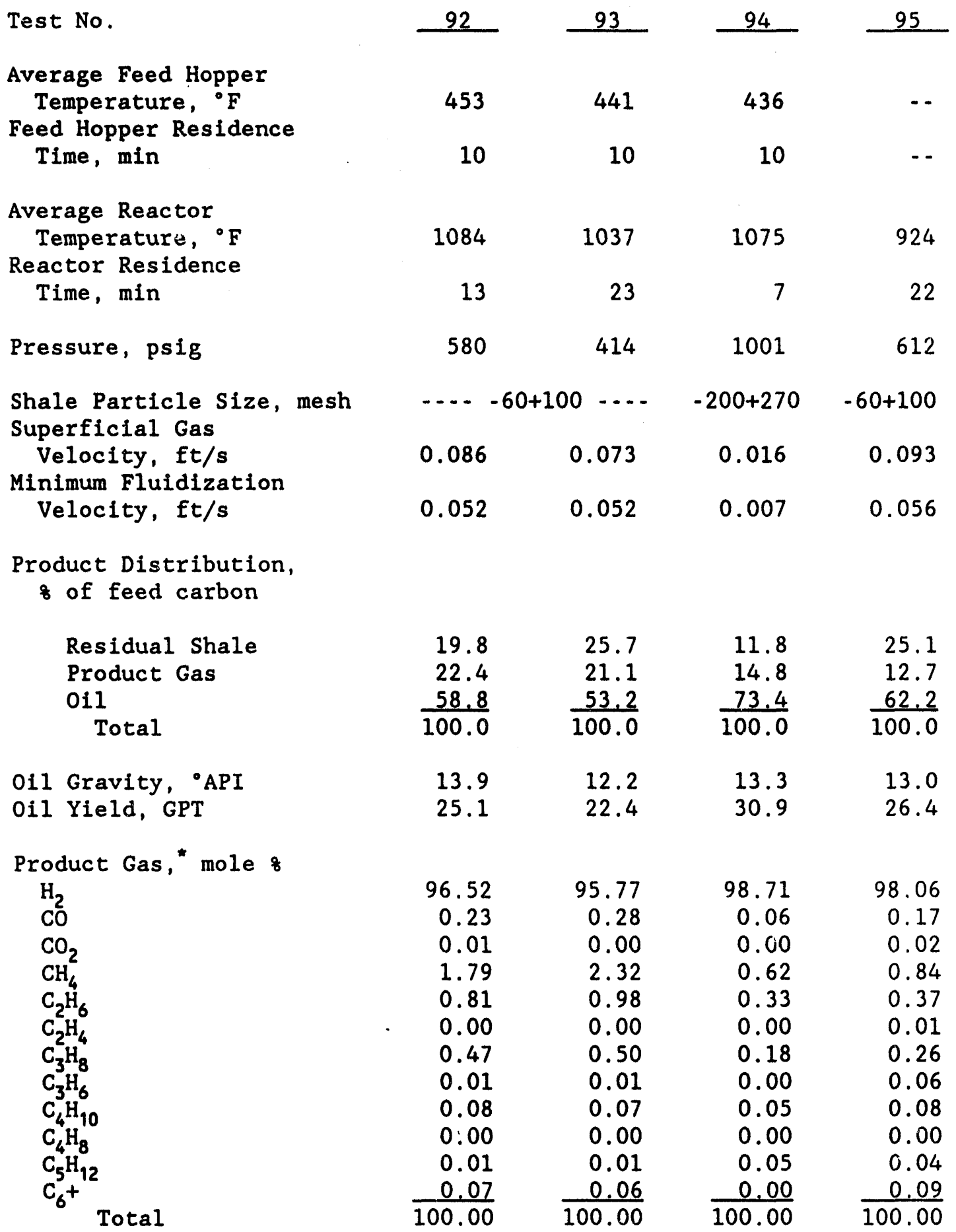

* $\mathrm{H}_{2} \mathrm{~S}$-free basis. 


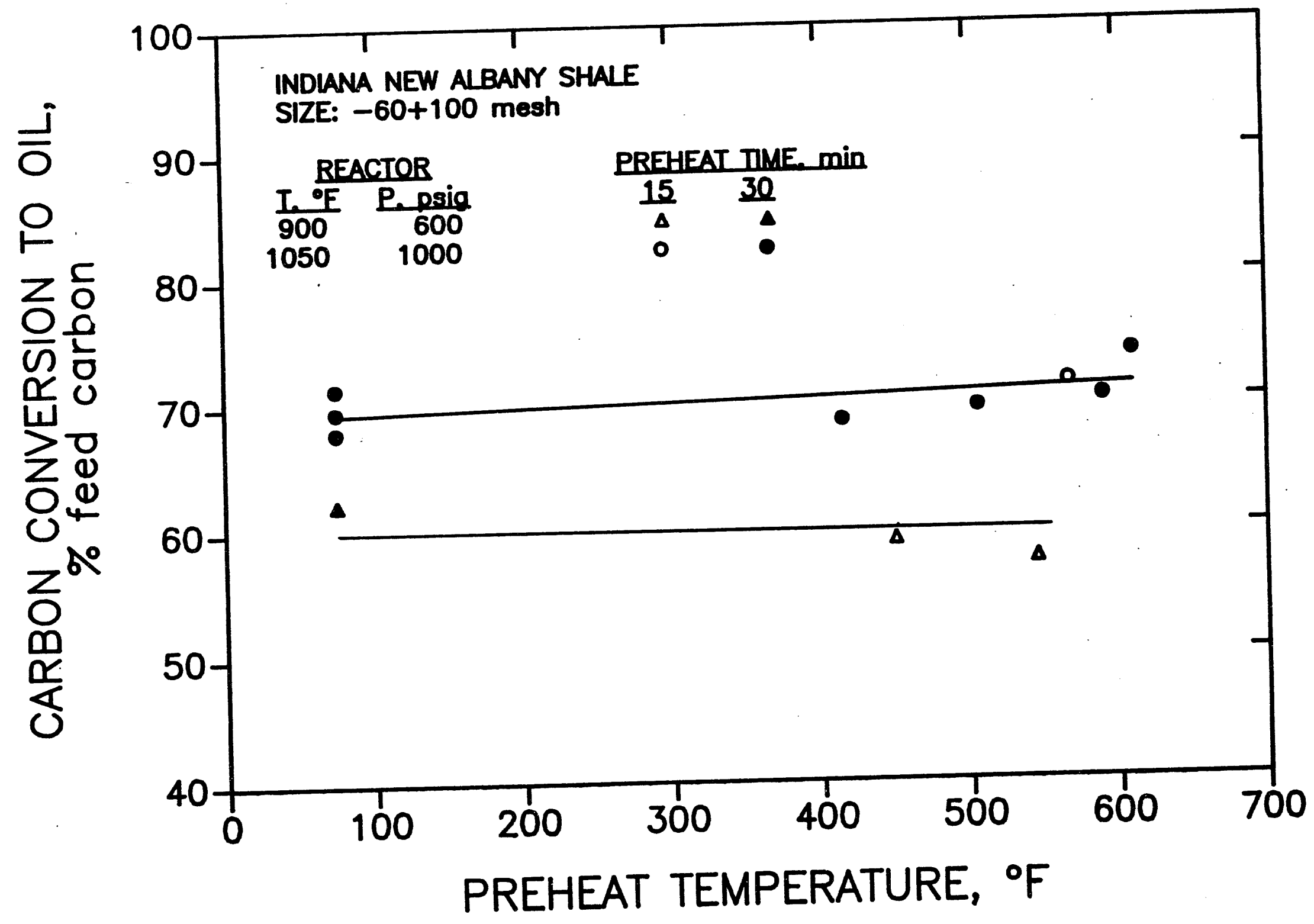

Figure 1-1. EFFECT OF PREHEAT TEMPERATURE ON FEED CARBON CONVERSION TO OIL 


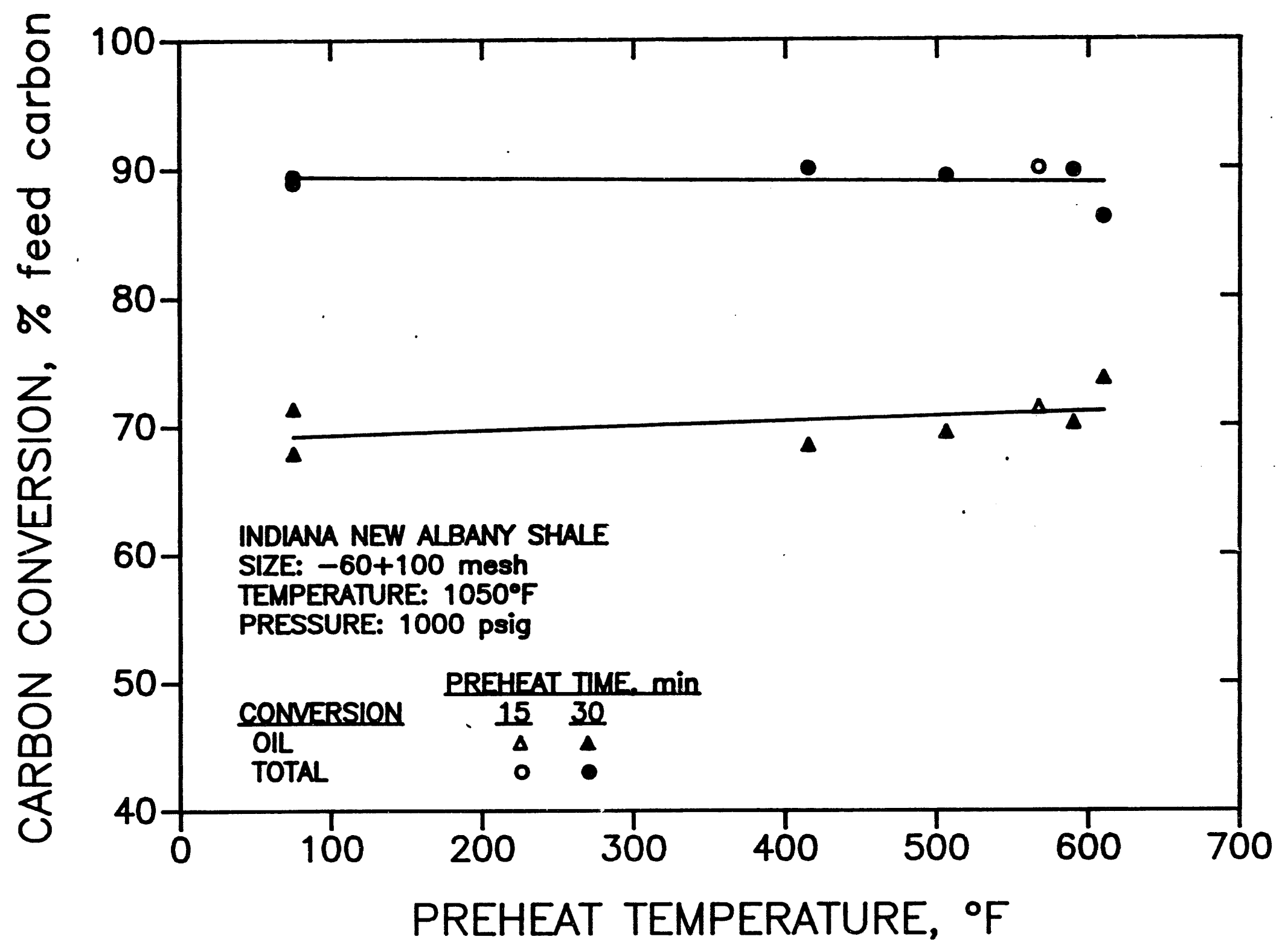

Figure 1-2. THE EFFECT OF PREHEAT TEMPERATURE ON FEED CARBON CONVERSION TO OIL 
The effects of particle size on carbon conversion to oil and gas are presented in Figure 1-3 for tests conducted with Indiana shale at $1050^{\circ} \mathrm{F}$ and $1000 \mathrm{psig}$ at a retorting residence time of at least 20 minutes. The particle size ranges tested include $-200+270,-100+140$ and $-60+100$ mesh. The results show that the carbon conversions to oil and gas are not affected by particle size within the ranges studied. The effects of larger particle sizes on oil yield and carbon conversion are being investigated and will be reported when the analyses are complete.

The results of $\mathrm{PFH}$ tests at $900^{\circ}$ and $1050^{\circ} \mathrm{F}$ with Indiana shale have shown that carbon conversion to oil and the total carbon conversion increase linearly with increasing hydrogen pressure in the range of 400 to 1000 psig. The effects of hydrogen pressure on carbon conversion are shown in Figures $1-4$ and 1-5. At $900^{\circ} \mathrm{F}$, the carbon conversion to 011 and total carbon conversion increase from 548 and 648 at $400 \mathrm{psig}$ to 728 and 858 at $1000 \mathrm{psig.} \mathrm{At} \mathrm{a} \mathrm{tem-}$ perature of $1050^{\circ} \mathrm{F}$, the carbon conversion to oil and total carbon conversion increase from 548 and 728 at 400 psig to 698 and 908 at 1000 psig.

The effects of reactor temperature and residence time on the carbon conversion to oil and the total carbon conversion are illustrated in Figures 1-6 and 1-7. At 1000 psig, the carbon conversion to gas increases with increasing retorting temperature between $850^{\circ}$ and $1300^{\circ} \mathrm{F}$. The oil yield, however, increases with increasing temperature to a maximum of 728 at $900^{\circ} \mathrm{F}$ and then decreases with further increases in temperature to $68 \%$ at $1300^{\circ} \mathrm{F}$. Tests at 600 psig showed a similar slight decrease in oil yield and increase in total carbon conversion with an increase in temperature from $900^{\circ}$ to $1100^{\circ} \mathrm{F}$.

Tests have been conducted in the batch $\mathrm{PFH}$ reactor at residence times as short as 4 minutes at $900^{\circ} \mathrm{F}$ and pressures of 600 and $1000 \mathrm{psig}$. At the conditions tested, reducing the residence time from 20 to 4 minutes does not appear to have any effect on the oil yield. However, decreasing the residence time from 20 to 4 minutes decreases the carbon conversion to gas. Further tests will be conducted to determine the effects of shorter residence times on the oil yield and carbon conversions. A reduction in the residence time would reduce the size of the $\mathrm{PFH}$ reactor, and a decrease in the hydrocarbon gas production would reduce hydrogen consumption.

\section{Subtask 1.2. Continuous Tests}

The objective of this task is to obtain steady-state data for laboratory-scale PFH processing in a continuous test unit for Indiana New Albany shale to determine the effects of temperature, pressure, fluidization gas velocity, and solids residence time on the product yields and quality.

\section{Discussion}

Three tests, including 1 successful test, were conducted this quarter in the continuous $P F H$ unit. The unsuccessful tests were performed at $900^{\circ} \mathrm{F}$ and 1000 psig. Both tests were terminated due to erratic residue solids discharge from the reactor. The unsuccessful test at $900^{\circ} \mathrm{F}$ and $1000 \mathrm{psig}$ will be repeated after equipment-modifications are completed to allow for more uniform solids discharge.

• 


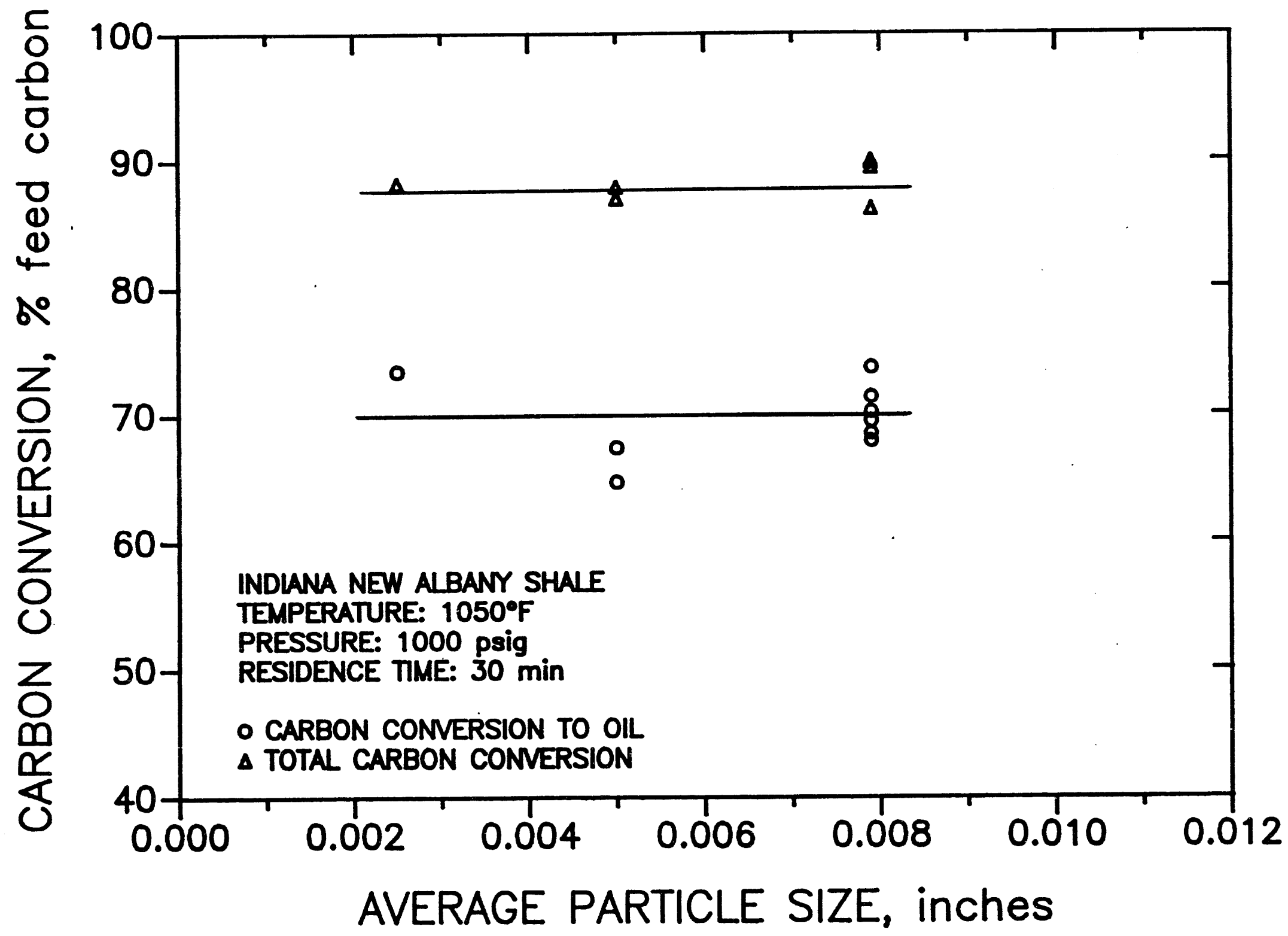

Figure 1-3. THE EFPECT OF PARTICLE SIZE ON FEED CARBON CONVERSION 


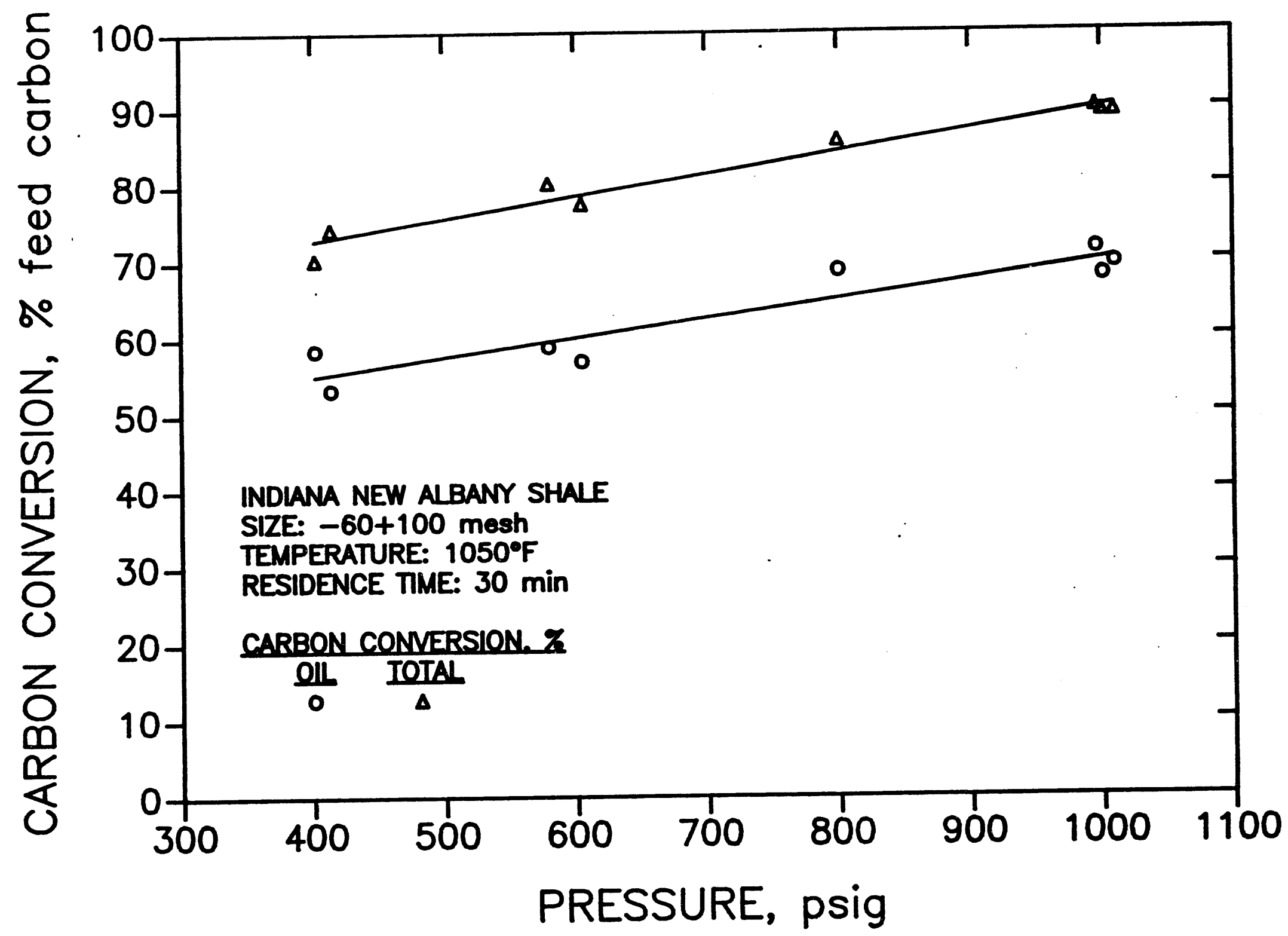

Figure 1-4. THE EFFECT OF HYDROGEN PRESSURE ON FEED CARBON CONVERSION AT $1050^{\circ} \mathrm{F}$ 


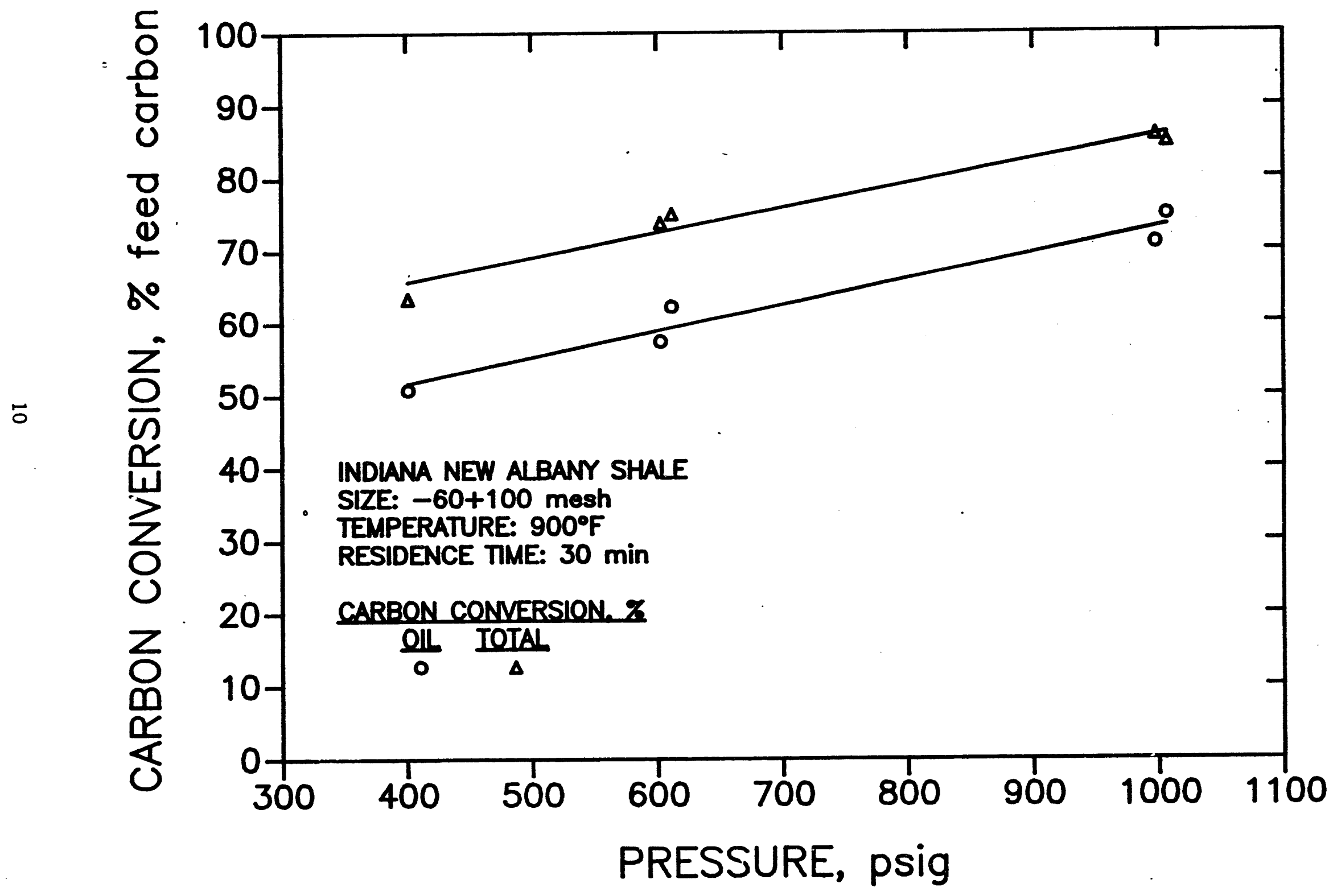

Figure 1-5. THE EFPECT OF HYDROGEN PRESSURE ON FEED CARBON CONVERSION AT $900^{\circ} \mathrm{F}$ 


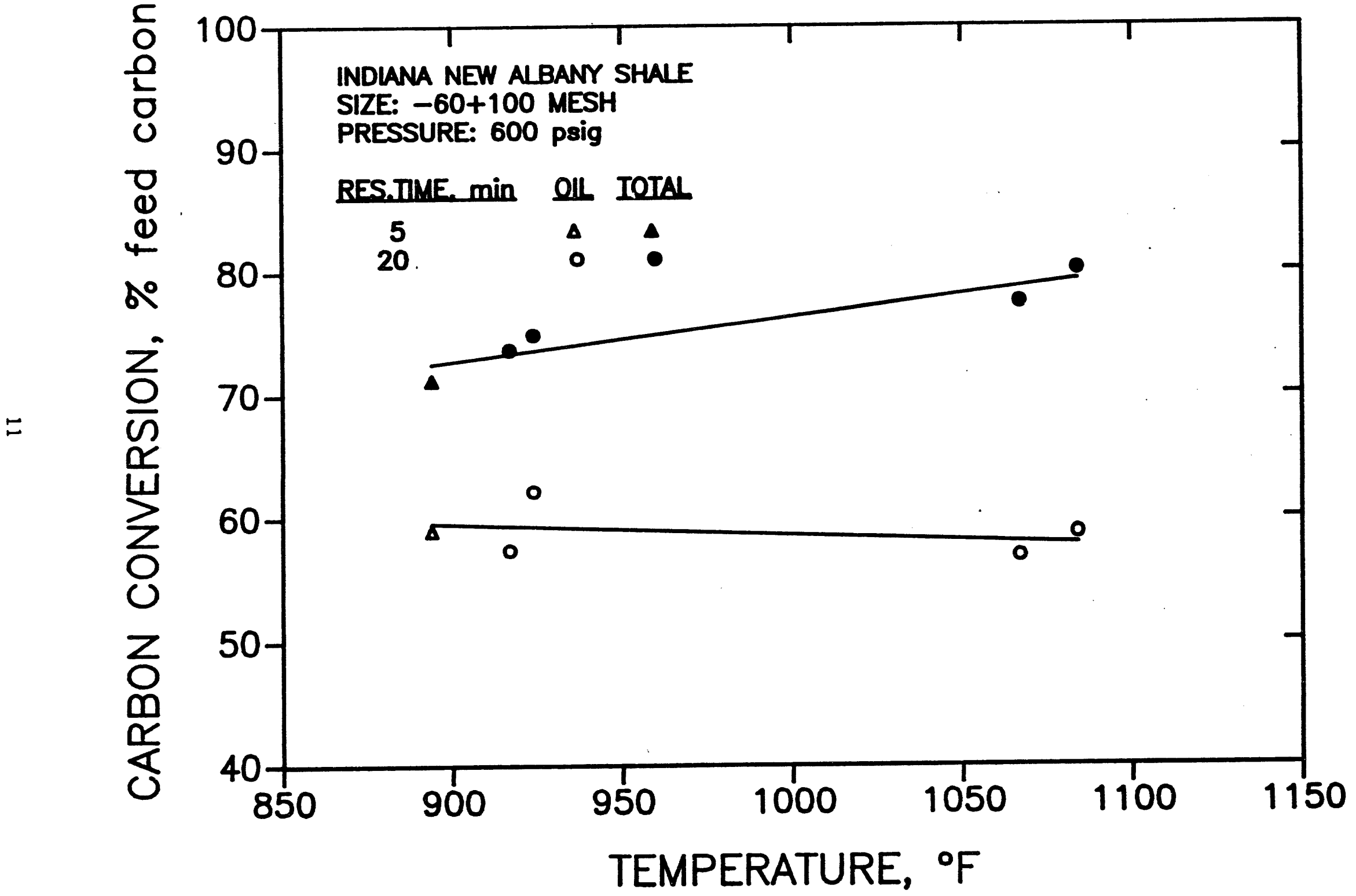

Figure 1-6. THE EFPECT OF HYDRORETORTING TEMPERATURE ON FEED CARBON CONVERSION AT 600 PSIG HYDROGEN PRESSURE 


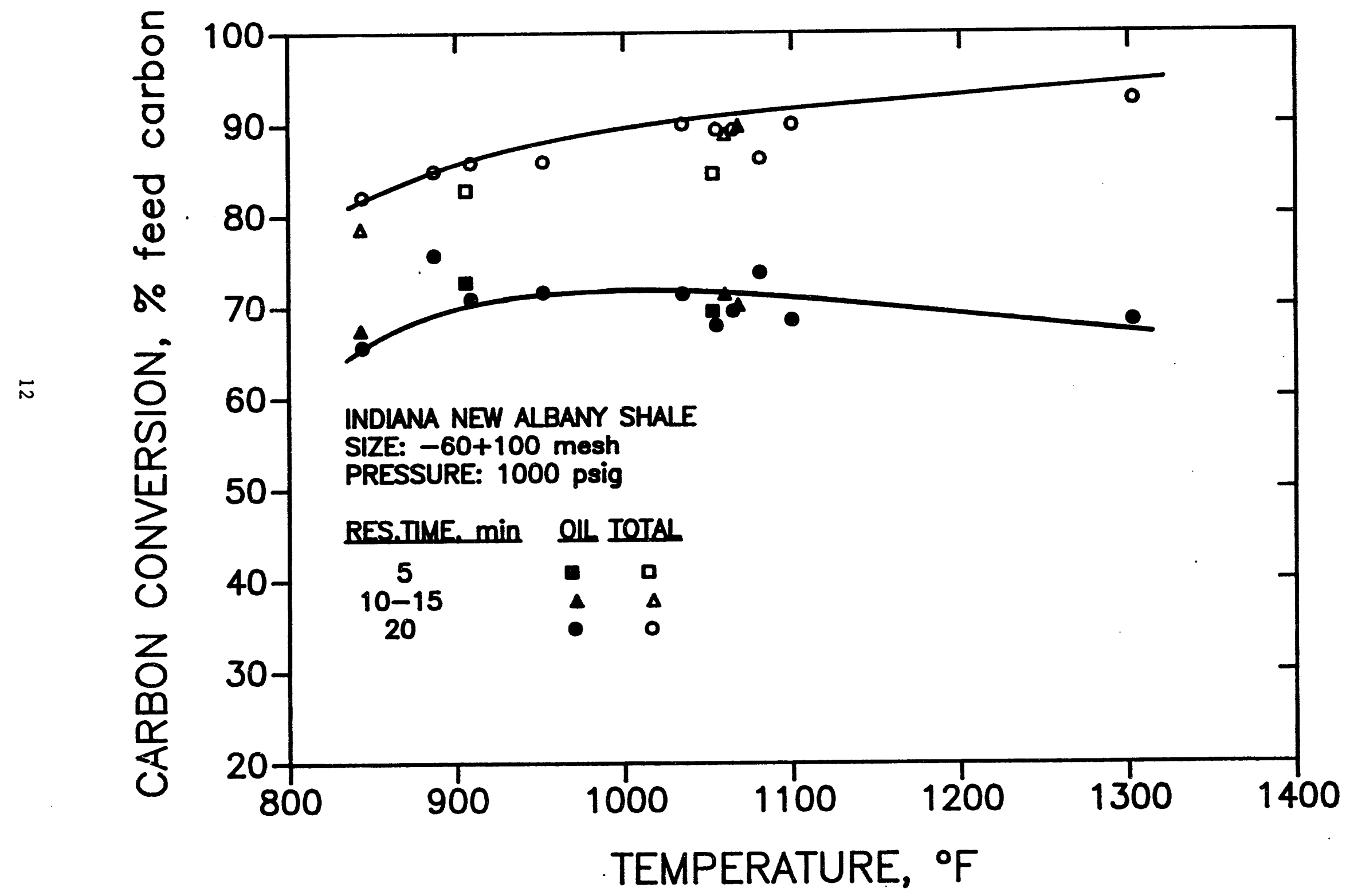

Figure 1-7. THE EFFECT OF HYDRORETORTING TEMPERATURE ON FEED CARBON CONVERSION AT 1000 PSIG HYDROGEN PRESSURE 
Test C-10 was conducted at a temperature of $900^{\circ} \mathrm{F}$ and hydrogen pressure of $400 \mathrm{psig}$ with $-60+100$ mesh Indiana shale. The average shale residence time was 36 minutes. A summary of the operating conditions and test results for Tests C-10 and C-7 (conducted last quarter) are presented in Table 1-2.

Carbon balances for the continuous PFH tests can be compared directly with carbon balances from batch tests conducted at similar conditions of temperature, pressure, and residence time. A comparison of the results from the 2 units shows that the carbon conversion to oil in the continuous unit is equal to or greater than the carbon conversion to oil in the batch unit. The carbon conversion to gas, however, is lower in the continuous unit than in the batch $\mathrm{PFH}$ reactor.

The carbon conversions to oil and gas achieved in Test C-7, conducted at $900^{\circ} \mathrm{F}$ and $600 \mathrm{psig}$, were 588 and 88 , respectively. Batch tests conducted at the same conditions had average carbon conversions to oll and gas of 608 and 118 The carbon conversions to oil and gas achieved in Test C-10, conducted at $900^{\circ} \mathrm{F}$ and $400 \mathrm{psig}$, were 618 and 48 , respectively. Batch tests at the same conditions had average carbon conversions to 011 and gas of 548 and 108.

Sulfur distributions for Tests C-7 and C-10 (Table 1-3) show that about 418 of the sulfur appears in the product gas as hydrogen sulfide $\left(\mathrm{H}_{2} \mathrm{~S}\right)$ and about 58 appears in the oil. These results are typical of the sulfur distributions obtained from hydroretorting Indiana shale at $900^{\circ} \mathrm{F}$. Most of the sulfur in the Indiana shale feed is in the form of pyrite $\left(\mathrm{FeS}_{2}\right)$. During hydroretorting approximately $1 / 2$ of the sulfur is removed through the formation of $\mathrm{H}_{2} \mathrm{~S}$. The $\mathrm{FeS}$ remaining in the shale is more stable than $\mathrm{FeS}_{2}$ and is usually not further reduced in the temperature range used for hydroretorting.

\section{Table 1-3. SULFUR DISTRIBUTIONS FOR INDIANA NEW ALBANY SHALE} CONTINUOUS PFH TESTS

Test No.

Operating Conditions

Average Reactor Temperature, ${ }^{\circ} \mathrm{F}$

Reactor Residence Time, min

Pressure, psig

Product Distribution, of feed sulfur

Residue Shale

Product Gas $\left(\mathrm{H}_{2} \mathrm{~S}\right)$

$0 i 1$

Total

$\begin{array}{rr}\text { C.7 } & \text { C }-10 \\ 900 & \\ 19 & 898 \\ 600 & 36\end{array}$

\begin{tabular}{rr}
54.2 & 54.0 \\
40.8 & 41.6 \\
5.0 & 4.5 \\
\hline 100.0 & 100.0
\end{tabular}

Additional tests will be conducted in the continuous PFH unit with Indiana shale to confirm the hydrocarbon gas yields and hydrogen consumptions. Tests will also be performed to examine the effects of shorter residence times on the oil yield, and carbon and sulfur conversions. Short residence time tests in the batch unit have shown that the oil-forming reactions are faster than the hydrocarbon-gas-producing reactions. Tests using short shale 
Table 1-2. SUMMARY OF TEST CONDITIONS AND RESULTS OF PFH CONTINUOUS TESTS WITH INDIANA NEW ALBANY SHALE

\begin{tabular}{|c|c|c|c|}
\hline Test No. & C-7 & & C-10 \\
\hline \multicolumn{4}{|l|}{ Operating Conditions } \\
\hline Average Feed Hopper Temperature, ${ }^{\circ} \mathrm{F}$ & 550 & & 355 \\
\hline Feed Hopper Residence Time, min & -. & & -. \\
\hline Average Reactor Temperature, ${ }^{\circ} \mathrm{F}$ & 900 & & 898 \\
\hline Reactor Residence Time, min & 19 & & 36 \\
\hline Pressure, psig & 600 & & 407 \\
\hline Shale Particle Size, mesh & $\ldots . .$. & $-60+100$ & 2..... \\
\hline Superficial Gas Velocity, ft/s & 0.078 & & 0.096 \\
\hline Minimum Fluidization Velocity, $\mathrm{ft} / \mathrm{s}$ & 0.056 & & 0.056 \\
\hline \multicolumn{4}{|l|}{ Operating Results } \\
\hline \multicolumn{4}{|l|}{ Product Distribution, $z$ of feed carbon } \\
\hline Residual Shale & 33.8 & & 35.6 \\
\hline Product Gas & 8.3 & & 3.6 \\
\hline Oil & 57.9 & & 60.8 \\
\hline Total & $\overline{100.0}$ & & $\overline{100.0}$ \\
\hline Oil Yield, GPT & 24.5 & & 26.7 \\
\hline Oil Gravity, ${ }^{\circ} \mathrm{API}$ & 13.2 & & 15.3 \\
\hline $0 i l$ Gravity, $\mathrm{g} / \mathrm{mL}$ & 0.978 & & 0.964 \\
\hline \multicolumn{4}{|l|}{ Product Gas," mol \& } \\
\hline $\mathrm{H}_{2}$ & 94.17 & & 89.89 \\
\hline Có & 0.31 & & 0.38 \\
\hline $\mathrm{CO}_{2}$ & 0.35 & & 0.08 \\
\hline $\mathrm{CH}_{4}^{2}$ & 1.50 & & 2.53 \\
\hline $\mathrm{C}_{2} \mathrm{H}_{6}^{4}$ & 0.78 & & 1.13 \\
\hline $\mathrm{C}_{2}^{2} \mathrm{H}_{4}^{\circ}$ & 0.10 & & 0.09 \\
\hline $\mathrm{C}_{3}^{2} \mathrm{H}_{8}^{4}$ & 0.37 & & 0.53 \\
\hline $\mathrm{C}_{3}^{3} \mathrm{H}_{6}^{0}$ & 0.13 & & 0.17 \\
\hline $\mathrm{C}_{4} \mathrm{H}_{10}$ & 0.16 & & 0.23 \\
\hline $\mathrm{C}_{4}^{4} \mathrm{H}_{8}$ & 0.13 & & 0.11 \\
\hline $\mathrm{C}_{5} \mathrm{H}_{12}^{8}$ & 0.10 & & 0.13 \\
\hline $\mathrm{C}_{6}+\mathrm{C}$ & 0.13 & & 0.20 \\
\hline $\mathrm{H}_{2} \mathrm{~S}$ & 1.77 & & 4.53 \\
\hline Total & $\overline{100.00}$ & & $\overline{100.00}$ \\
\hline
\end{tabular}

* At the end of the steady-state period. 
residence times in the continuous unit may help to determine the relative rates of production of oil, hydrocarbon gases, and $\mathrm{H}_{2} \mathrm{~S}$.

\section{Task 2. PFH Optimization Tests}

The objective of this task is to obtain laboratory-and bench-scale data for optimizing the PFH process with 6 Eastern oil shales. This task is divided into 4 subtasks: Lab-Scale Batch Tests, Lab-Scale Continuous Tests, Bench-Scale Tests, and Data Analysis and Correlations.

\section{Subtask 2.1. Lab-Scale Batch Tests}

The objective of this subtask is to determine the effects of temperature and pressure on oil yields from the PFH process. The batch retort used for Subtask 1.1 will be used in this subtask. Each of the 5 remaining Eastern oil shales will be tested at temperatures ranging from $900^{\circ}$ to $1200^{\circ} \mathrm{F}$ at reactor pressures from 400 to 1000 psig. AlI other operating variables will be selected based on the results from Task 1.

\section{Discussion}

Five tests, including 4 successful tests, were conducted this quarter in the batch PFH unit. The unsuccessful test was involuntarily terminated due to a leak in the recycle gas compressor. The compressor leak was fixed, and the test was repeated.

The 4 successful tests were conducted to repeat earlier tests that showed inconsistent results when compared with the entire data base. Four different shales were hydroretorted at the operating conditions listed in Table 2-1. The results of these tests will be reported when laboratory analyses are completed.

These repeat tests complete the work planned to be conducted for Subtask 2.1. A review of all the batch test results will be made to determine if any additional tests are needed to complete the data base for the 5 shales.

\section{Subtask 2.2. Lab-Scale Continuous Tests}

The objective of this subtask is to obtain steady-state data for labscale PFH processing of the 5 other key Eastern shales. Steady-state data are necessary for obtaining reliable process material balances and for characterizing gaseous, liquid, and solid products.

\section{Discussion}

Six tests, including 3 successful tests, were conducted this quarter in the continuous $\mathrm{PFH}$ reactor. The 3 unsuccessful tests were terminated due to various equipment problems including a leak in a compressor seal and a plug in the recycle gas filter. The equipment was repaired and/or cleaned and the tests were repeated. The pressure equalizing lines were nodified to eliminate the pressure differential between the reactor and feed hopper. A recording 
chart was installed to provide a continuous recording of the bed level and the differential pressure across the reactor.

Table 2-1. SUMMARY OF TEST CONDITIONS FOR BATCH PFH TESTS

Test No.

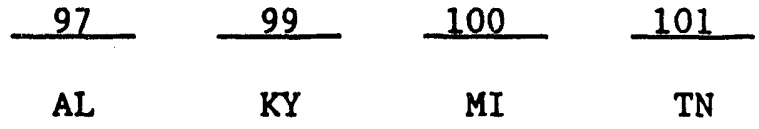

Shale

Operating Conditions (Nominal)

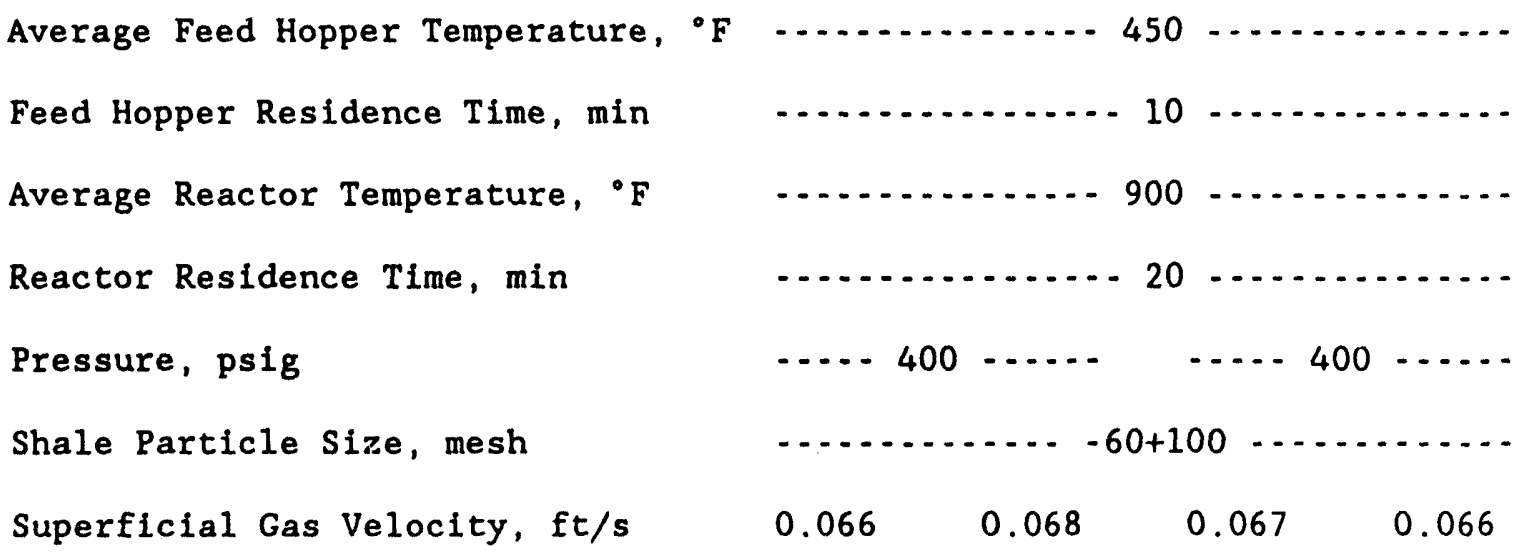

Minimum Fluidization Velocity, $\mathrm{ft} / \mathrm{s}$

0.056

Tests with Alabama Chattanooga, Kentucky New Albany, and Ohio Cleveland shales were conducted at a temperature of $900^{\circ} \mathrm{F}$ and a hydrogen pressure of 600 psig. The tests were conducted at $900^{\circ} \mathrm{F}$, because the results of earlier batch tests (Subtask 2.1) indicated that the highest oil yield for these shales was obtained at this temperature. All tests were made with a shale residence time of approximately 30 minutes. A shale particle size of $-40+60$ mesh was utilized for these tests. A summary of the operating conditions for the tests conducted in the PFH reactor is presented in Table 2-2.

Results of these tests will be presented when the product analyses have been completed. Comparisons will also be made between the oil yields and total carbon conversions of the various shales in the batch and continuous reactors. Sulfur balances will be presented for the continuous PFH tests.

During the next quarter, continuous PFH tests will be conducted with the Michigan Antrim and Tennessee Chattanooga shales. The Tennessee shale will be retorted at the same condition as the 3 shales studied this quarter. The Michigan shale, however, will be retorted at a PFH temperature of $1050^{\circ} \mathrm{F}$. Batch tests with this shale showed that the maximum oil yield was obtained at $1050^{\circ} \mathrm{F}$. The oil yield for the other 5 shales studied has been found to be highest at $900^{\circ} \mathrm{F}$. 


\section{Subtask 2,3, Bench-Scale Tests}

The objectives of this subtask are to determine the effects of using a range of particle sizes (below $1 / 8$ inch), and process scale-up from laboratory- to bench-scale using a modified reactor system, and to provide data for environmental mitigation analyses. This subtask is further divided into two subtasks: Equipment Modification and Bench-Scale Tests.

Table 2-2. SUMMARY OF TEST CONDITIONS FOR CONTINUOUS PFH TESTS

Test No.

Shale

Operating Conditions (Nominal)

Average Feed Hopper Temperature, ${ }^{\circ} \mathrm{F}$

Feed Hopper Residence Time, min

Average Reactor Temperature, 'F

Reactor Residence Time, min

Pressure, psig

Shale Particle Size, mesh

Superficial Gas Velocity, ft/s

Minimum Fluidization Velocity, ft/s
C- 14

AL

C. 15

KY

325

314

919

919

922

27

33

28

598

602

596

$\ldots \ldots .6-60+100$

0.113

0.155

0.127

\section{Discussion}

During the quarter, the product gas heat exchanger was ordered from the vendor that submitted the lowest bid. Changes in the design pressure and temperature, and the gas inlet head of the product gas heat exchanger require that the equipment vendor prepare new design drawings. Delivery of the heat exchanger is, therefore, expected in November, pending approval of the final design drawings by IGT. The stainless steel expansion joint for the new reactor insert was received this quarter.

Data acquisition hardware and software from several sources were evaluated for use on the bench-scale unit. The hardware and software necessary for a 48-analog-input data acquisition system was ordered from MicroStar Laboratories.

Modification of the high-pressure, high-temperature unit continued this quarter with the removal of the existing reactor insert and installation of the 3 air-driven gas recycle compressors. An overall equipment schematic dia- 
gram (Figure 2-1) was prepared to facilitate the specification of all necessary ancillary equipment, valves, and piping.

\section{Subtask 2.4. Data Analyses and Correlations}

The objectives of this subtask are to analyze the data obtained in Tasks 1 and 2 and to develop correlations describing the performance of various shales in the PFH process. Data from the batch and continuous $1 \mathrm{ab}$ - and benchscale tests generated in the above subtasks will be used to develop empirical correlations that will relate the effects of operating temperature and pressure on oil, gas, and water ylelds and conversions of carbon, hydrogen, sulfur, and nitrogen.

\section{Discussion}

Data from the tests conducted this quarter have been included in the $\mathrm{PFH}$ data base. Batch PFH tests with Indiana New Albany shale (Subtask 1.1) and the other 5 Eastern shales (Subtask 2.1) have now been essentially completed. Work is continuing to develop empirical correlations to describe the $\mathrm{PFH}$ oil yields and carbon conversions in relation to the temperature, pressure, and shale residence time.

\section{Task 3. Testing of Process Improvement Concepts}

The objective of this task is to obtain data on novel process concepts that have the potential for improving the overall economics of PFH processing with Eastern oil shales. This task is divided into 5 subtasks corresponding to the 5 concepts being testing. In-Bed Sulfur Capture, Electrostatic Desulfurization, Microbial Desulfurization and Denitrification, Electroseparation of $0 i 1$ Shale and Fines, and Restricted Pipe Discharge System (RPDS).

\section{Subtask 3,1. In-Bed Sulfur Capture Tests}

The objective of this subtask is to determine the effects of operating conditions (temperature, pressure and limestone/siderite-to-shale ratios) on the effectiveness of in-bed sulfur capture with limestone and presintered iron ore (siderite).

\section{Discussion}

One test was conducted this quarter to determine the effectiveness of calcined limestone as a material for PFH in-bed sulfur capture. The calcined limestone was prepared prior to the batch $\mathrm{PFH}$ test and was determined to contain only 1.4 wt 8 calcium carbonate. The same calcined limestone will be used next quarter for batch tests at other conditions.

Sulfur analyses were performed on samples of Indiana New Albany shale feed and residue from the batch $\mathrm{PFH}$ limestone test and a number of batch $\mathrm{PFH}$ tests made previously with no limestone addition. Sulfur contents of a number of the product oils were also determined. The sulfur content of oil from PFH processing ranges from 1.0 to 1.3 wt 8 , or about $3.0 \%$ to $4.0 \%$ of the feed shale sulfur. The results of the analyses are presented in Table 3-1. 


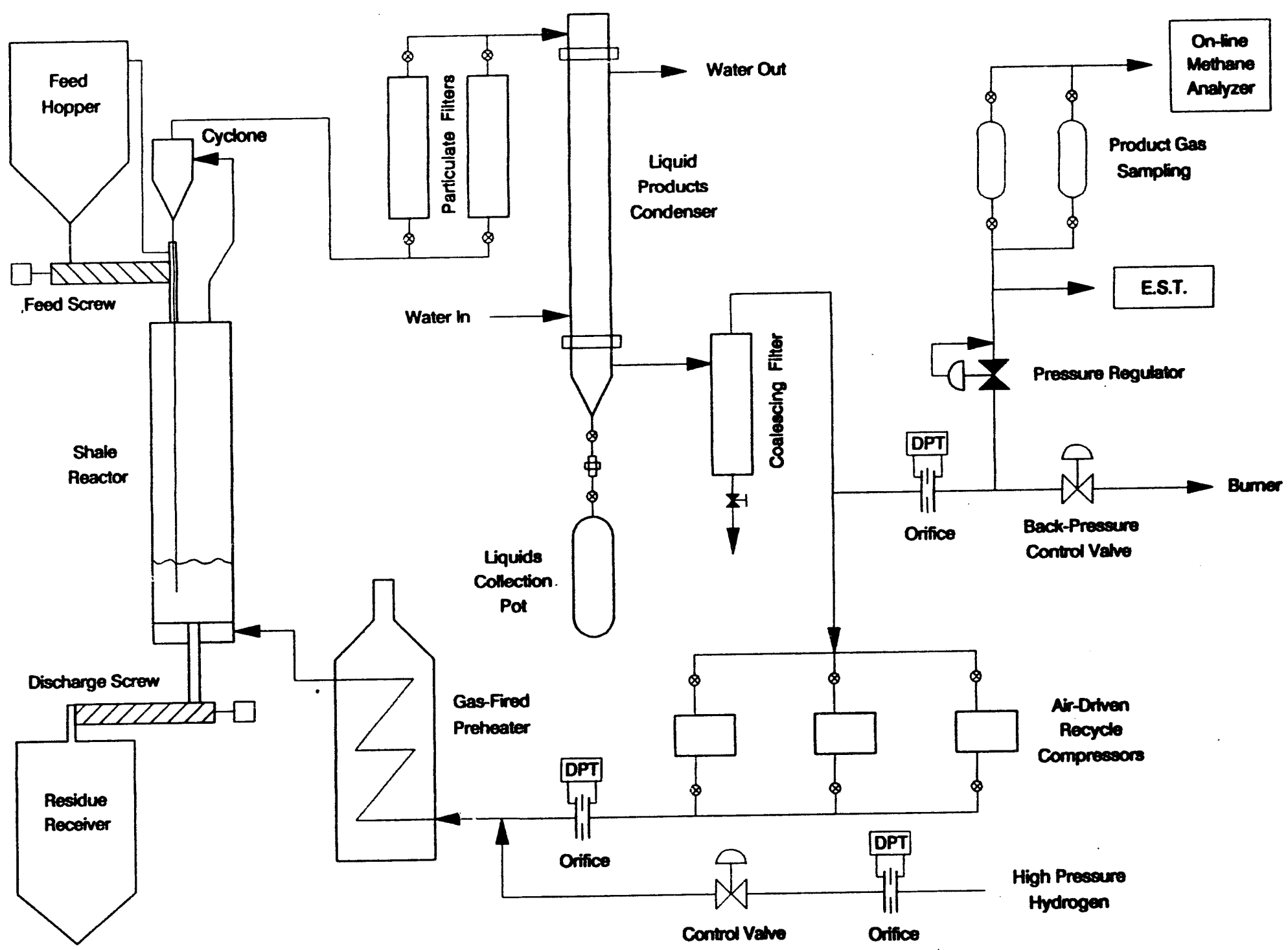

Figure 2-1. SCHEMATIC DIAGRAM OF EQUIPMENT LAYOUT 
Table 3-1. SULFUR CONVERSIONS ACHIEVED IN BATCH PFH TESTS WITH INDIANA NEW ALBANY SHALE

\begin{tabular}{|c|c|c|c|c|c|c|c|c|c|c|}
\hline Test & Temp., & Press., & Residence & Sorbent & $\mathrm{Ca} / \mathrm{S}$ & sulfi & - Conten & we $x$ & $\begin{array}{l}\text { Sul tur } \\
\underline{x} \text { of } F\end{array}$ & $\begin{array}{l}\text { ersion, } \\
\text { sulfur, }\end{array}$ \\
\hline No. & $-\underline{-F}$ & osig & Time, min & Used? & mol ratio & Feed & Residue & oil & Oil & Total \\
\hline 70 & 843 & 1009 & 14 & No & $M A^{1}$ & 3.07 & 1.92 & NA & NA & 48.0 \\
\hline 89 & 908 & 409 & 18 & No & NA & 3.07 & 1.70 & 0.92 & 3.0 & 52.7 \\
\hline 90 & 894 & 602 & 4 & No & NA & 3.07 & 1.87 & MA & NA & 48.3 \\
\hline 84 & 917 & 615 & 22 & No & NA & 3.07 & 1.98 & NA & NA & 45.9 \\
\hline 79 & 906 & 1003 & 4 & No & NA & 3.07 & 1.99 & NA & NA & 46.9 \\
\hline 91 & 896 & 1020 & 23 & No & MA & 3.07 & 1.71 & 0.96 & 3.5 & 54.3 \\
\hline 93 & 1037 & 420 & 23 & No & NA & 3.07 & 2.05 & 1.29 & 3.9 & 44.4 \\
\hline 92 & 1084 & 597 & 13 & No & NA & 3.07 & 2.49 & 1.08 & 3.6 & 33.0 \\
\hline 55 & 1053 & 1002 & 6 & No & NA & 3.07 & 2.10 & NA & NA & 43.9 \\
\hline 47 & 1060 & 988 & 13 & No & HA & 3.07 & 2.05 & NA & NA & 46.4 \\
\hline 103 & 1051 & 599 & 3 & Yes $^{2}$ & 1.5 & 3.07 & 3.19 & 1.24 & 3.7 & 9.3 \\
\hline
\end{tabular}

1 Not available.

2 calcined limestone.

3 By shale weight balance. 
Total sulfur conversions were calculated on the basis of shale weight. The conversion of sulfur in PFH tests without limestone addition was found to average 47.9 wt \& (the standard deviation for 9 samples was 3.58 ) except for Test 92, which was 33.0 wt 8 . No correlation was observed between total sulfur conversion and temperature, pressure, or residence times in the ranges of $843^{\circ}$ to $1084^{\circ} \mathrm{F}, 400$ to $1000 \mathrm{psig}$, or 3 to $23 \mathrm{~min}$.

In Test 103, a sufficient quantity of calcined limestone was added to the Indiana feed shale to provide 1.5 moles of calcium per mole of feed sulfur. If 508 of the sulfur was converted during hydroretorting, the ratio of calcium to converted sulfur would then be $3: 1$. Test 103 was conducted at $1050^{\circ} \mathrm{F}$ and $600 \mathrm{psig}$ with a residence time of 3 minutes. The addition of limestone reduced the sulfur conversion from the expected 508 to 9.38. Analyses of the product gas from this test revealed only trace amounts of $\mathrm{H}_{2} \mathrm{~S}$.

The addition of the calcined limestone did not alter the sulfur content of the shale oil or the conversion of sulfur to oil. The product oil contained 1.24 wt sulfur, or 3.7 wt $\&$ of the feed sulfur. Chemical analyses show that the oil obtained from PFH processing of Indiana shale generally contains from 1.0 to 1.3 wt 8 sulfur, or about 3.58 to 4.08 of the feed shale sulfur.

Additional tests will be conducted next quarter with Indiana New Albany shale and calcined limestone. The objective of these tests will be to determine the effects of temperature, pressure, limestone-to-shale ratio, and residence time on the in-bed sulfur capture ability of the limestone.

\section{Subtask 3.2. Electrostatic Desulfurization}

The objective of this subtask is to remove pyritic sulfur from Eastern oil shales using an electrostatic process. This subtask is being conducted by the Illinois Institute of Technology (IIT).

During the quarter, IIT developed a simple mathematical model to simulate the kerogen concentration profiles in the batch electrostatic separator. This model is essentially an extension of the theory used for designing industrial electrostatic precipitators. In principle, the batch electrostatic separator is similar to a 2-stage electrostatic precipitator. In the latter, particles are separated from a gas stream; in the former, a gas stream is used to separate one kind of particle from solid mixture. In both processes sur. face charge is the driving force for the separation. The IIT batch system works in dilute-phase mode (solid loadings of about $0.1 \mathrm{lb}$ solids/lb air).

IIT used a diffusion equation of species to determine the kerogen concentration profiles. The solution of this diffusion equation requires a value of particle diffusivity, which was estimated from Soo's theory ${ }^{\prime}$ of fine particle suspensions. According to this theory, the particle diffusivity should be similar to that of the fluid diffusivity. As calculations indicated that the flow in the separator was turbulent in nature, the value of the fluid diffusivity was approximated by the eddy diffusivity. The value obtained agreed well with that from Gidaspow's relative velocity model ${ }^{2}$ for multiphase flow. 
The following simplifying assumptions were made so that the governing partial differential equation could be solved. 1) The motion of the fluid phase is unaffected by the motion of the particles. 2) The field created by the charged particles is negligible compared to the applied electric field (the suspension is very dilute). 3) The adhesion of the particulate matter to the walls or electrodes is due to the presence of field forces. 4) Steadystate conditions prevail, i.e. as soon as particles are deposited, they are removed. 5) Plug-flow conditions exist in the channel.

The value of the particle charge was found to be a key parameter determining the kerogen and mineral matter concentration profiles, as expected.

A preliminary comparison of the experimental data with the model (see Figure 3-1) indicates that the trend is correct. However, the kerogen concentrations predicted by the model are higher than the experimentally measured values. Part of this discrepancy could be attributed to the uncertainties in the surface charge values for kerogen and mineral matter, as neither one of these was available for direct charge measurement. Other sources of difference may be the simplifying assumptions of plug flow and steady-state conditions. An exponential relation was found to exist between the kerogen concentration and the length of the separator, indicating that an outlet should be made in the negative electrode near the inlet to withdraw the kerogen stream. A conceptual design of such a separator was proposed for fabrication and testing in the future.

A well-characterized model system, such as silica sand mixed in charcoal, will be tested in the batch separator, so that the results can be compared to the theory. These tests will provide a check on the validity of the simple model.

\section{Subtask 3.3. Microbial Desulfurization and Denitrification}

The overall objective of this subtask is to achieve microbial removal of organic sulfur and nitrogen from shales. Work on Subtask 3.3.1 (Culture Development) is being conducted by Ohio State University (OSU). The objective of this subtask is to develop microbial cultures for the biological removal of organic nitrogen and sulfur from Eastern oil shale.

\section{Subtask $3,3,1$. Culture Development}

During the quarter, OSU continued work on developing cultures for biologically removing sulfur and nitrogen from shale.

A mixed-culture inoculum was applied to wet-sieved $+200,-200$, and -325 mesh pretreated shale samples in sulfur-free ( $\mathrm{S}$-free) medium at $\mathrm{pH} 7.0$ and $25^{\circ} \mathrm{C}$ for 20 days. After incubation, the shale from the inoculated flasks showed sulfur reductions of 5.968 and $2.88 ; 8.738$; and 6.58 and 6.008 , respectively. The decrease in the sulfur content of the $+200,-200$ and -325 mesh samples resulting from pretreatment in $5 \mathrm{M}$ nitric acid for 2 hours were 50.48 , 50.58 and 56.38 , respectively. The uninoculated controls showed less than 18 reduction in sulfur content. 


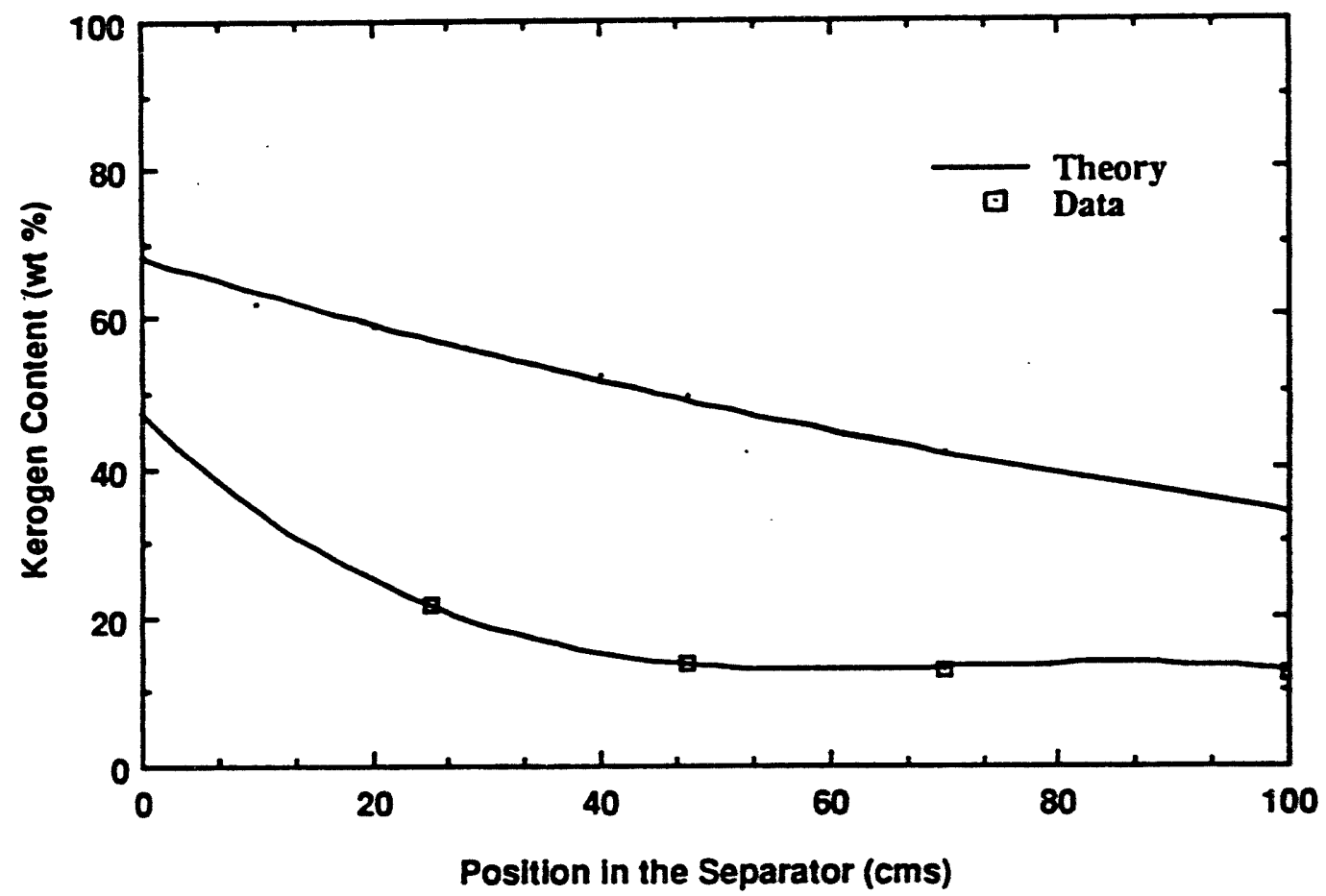

Figure 3-1. COMPARISON OF THE EXPERIMERTALLY OBTAINED DATA FroN THE BATCH SEPARATOR WITH THOSE PREDICTED BY THE WODBL 
The inoculum for these tests was prepared by suspending stock cultures from Indiana shale maintained on agar slants in sterile double distilled (dd) water. The suspension was centrifuged, rinsed twice and resuspended in dd water. Plate counts showed that the inoculum to contain $2.6 \times 10^{7} \mathrm{CFU} / \mathrm{mL}^{1}$. A 1 -mL aliquot of the inoculum was added to each of 5 flasks containing $100 \mathrm{~mL}$ of sterile sulfur-free medium. One gram of wet-sleved +200 or -325 mesh pretreated shale sample was added to 2 each of these flasks. One gram of wetsieved -200 mesh pretreated shale sample was added to the fifth inoculated flask. Three other flasks, each contalning $100 \mathrm{~mL}$ sterile sulfur-free medium and either a 1 -gram sample of $+200,-200$ or -325 mesh wet sleved shale were not inoculated. After incubation at $25^{\circ} \mathrm{C}$ on a rotary shaker, the shale was recovered by filtration, dried overnight at $70^{\circ} \mathrm{C}$ and analyzed in the energy dispersive $x$-ray spectrometer (EDXS) under conditions described in previous quarterly reports.

OSU isolated microorganisms from a sample of Meigs Creek No. 9 coal. A 20-gram fragment of coal was obtained from the center of a larger chunk. The fragment was aseptically ground and screened to $+200,-200$, and -325 mesh fractions. Twelve flasks containing sulfur-and nitrogen-free medium at pH 5 , 6,7 , and 8 were each inoculated with a 1-gram sample of the -325 mesh coal. One flask at each $\mathrm{pH}$ was incubated on a rotary shaker at either $25^{\circ}, 35^{\circ}$ or $50^{\circ} \mathrm{C}$ for 14 days. Serlal dilutions from each flask were prepared and spread plated onto agar. After incubation, colonies with unique morphology were selected and restreaked for isolation. A total of 16 apparently distinct colony types were isolated.

OSU also used a NIOSH method for asbestos fiber analysis to enumerate the organisms associated with freshly ground shale and coal particles. The modified NIOSH method allows for microorganisms associated with the particles to be quantitated by direct count in the transmission electron microscope (TEM), which is the accepted method for enumerating fibers in asbestoscontaining samples. A standard plating method was used to enumerate the viable microorganisms in a similar sample of shale particles.

The numbers of microorganisms in samples of wet-sieved shale and coal particles, by direct count in the TEM, were determined to be $4.0 \times 10^{10}$ and $1.09 \times 10^{10} \mathrm{cell} / \mathrm{gram}$, respectively. When aliquots of dd water used to wetsieve the samples were spread plated, only $10^{10}$ cell/gram were observed. These results indicate that there are organisms present that may not be viable or are viable but not culturable by the methods being used.

The TEM was also used to measure the dimensions of shale particles in each of the size fractions obtained by wet sieving. The average length and width of shale particles were measured to be 21.1 and 22.5 microns, 11.9 and 12.3 microns, and 9.0 and 9.0 microns, respectively, for the $+200,-200$ and -325 mesh fractions. For comparison, the sieve openings for the 200 and 325 screens are 74 and 44 microns, respectively.

* Colony-forming units per milliliter. 
OSU also prepared a cell lysate (by cryolmpaction) and a cell-free extract of a mixed culture that had been exposed to pretreated Indiana shale in S-free medium for 11 days. Portions of the lysate and filtrate were added to freshly pretreated shale samples for 4 hours. These samples and the shale from the original batch cultures are being prepared for sulfur analysis.

Two batch cultures were each grown in 111 ter of s-free medium at pH 7 . Ten grams of $\mathrm{HNO}_{3}$-pretreated, wet-sieved -325 mesh shale were added to both. The pretreatment resulted in sulfur reductions of 54.78 and 53.28 of these samples. The inoculum for this experiment was a 1 -mL aliquot of supernatant collected from the flask in the first set of experiment mentioned above, that showed a sulfur reduction of 8.738 . The cultures were incubated at room temperature on a rotary shaker for 11 days. The flasks were removed from the shaker, allowed to settle for 1 hour, and the culture medium poured into centrifuge tubes. The supernatant was removed and saved; the cell pellets were resuspended in water and centrifuged again (this was done twice). The rinsed cell pellets were then placed into a precooled stainless steel chamber filled with liquid nitrogen. A precooled stainless steel ball was added and the chamber was mechanically reciprocated 750 time/min for 2.5 minutes.

This cryoimpaction technique has been previously demonstrated to rupture approximately 988 of the cells without significantly diminishing the activity of cellular enzymes. The resulting powdered cell lysate was collected with a precooled spatula and a portion was transferred to precooled freezer ampules and stored in liquid nitrogen. The majority of the lysate was placed into a sterile flask and refrigerated. The supernatant was centrifuged, sterilized by filtration through a 0.45 microns filter (Whatman), and stored in a refrigerator. The test and control shale samples were pretreated, wet-sieved - 325 mesh hand-ground or beneficlated shale. Four 1-gram pretreated, handground and beneficlated shale samples were each suspended in $50 \mathrm{~mL}$ buffer at $\mathrm{pH} 7$. To each of these flasks were added about equal volumes of the refrigerated lysate. The flasks were placed onto a rotary shaker at room temperature for 3 hours, allowed to settle for $1 / 2$ hour and the shale collected by centrifugation. Two 1 -gram pretreated beneficiated shale samples were sus. pended in $50 \mathrm{~mL}$ buffer at $\mathrm{pH} 7$ and 4 others were suspended in $50 \mathrm{~mL}$ of the filtrate. The 6 flasks were placed onto a rotary shaker at room temperature for 3 hours, allowed to settle $1 / 2$ hour, and the shale collected by centrifu. gation. The shale samples are being dried and prepared for sulfur analysis.

\section{Subtask $3,3,2$ Microbial Process Development}

The objective of this subtask is to determine the effects of process conditions and inocula from Subtask 3.3.1 (which involves development of cultures to desulfurize and/or denitrify shale) on the efficiencies and rates of organic nitrogen and sulfur removal from Eastern shale.

During the quarter, IGT conducted experiments with IGTS8 - a sulfur metabolizing culture - to compares its growth in the presence of either shale or sodium sulfate $\left(\mathrm{Na}_{2} \mathrm{SO}_{4}\right)$ as the sole source of sulfur. The test results indicated that the growth of IGTS8 in a mixture of shale and $\mathrm{Na}_{2} \mathrm{SO}_{4}$ was similar to that in $\mathrm{Na}_{2} \mathrm{SO}_{4}$ alone. The presence of shale was apparently not inhibitory to the growth of IGTS8. However, the growth of IGTS 8 in shale 
without $\mathrm{Na}_{2} \mathrm{SO}_{4}$ was only 318 that with $\mathrm{Na}_{2} \mathrm{SO}_{4}$ alone. IGTS8 is apparently not able to utilize the sulfur present in the shale under the conditions tested.

Since no culture to date has shown significant sulfur removal from shale, a mixed culture was examined for its ability to remove both sulfur and nitrogen. The mixed culture was composed of IGTS8, 17 cultures from OSU (ob. tained previously), and the culture from IGT's shale bioreactor. After 14 days of incubation, a 248 reduction in sulfur was achieved from the sample with 4 wt shale, culture, and glucose. In the sample with 4 wt 8 shale, culture, but no glucose, a 198 sulfur reduction was achieved. Abiotic controls yielded no sulfur reductions.

Microbial cells were added to the sample and control flasks to yield a final concentration of $10^{8} \mathrm{cell} / \mathrm{mL}$. Cell growth was monitored by plate counts on nutrient agar. Plate counts for samples with and without glucose showed $10^{8} \mathrm{ce} 11 / \mathrm{mL}$, Indicating that the organisms were not actively growing, but were merely maintaining themselves on the shale. Five different types of colonies were observed on the agar plates ( 2 yellow, 1 orange, 1 small and 1 large white colonies), but that of IGTS 8 was not observed.

The data suggest that a mixed culture has been developed that is capable of removing sulfur from shale. The mechanism for sulfur removal may involve an enzyme system developed by the organism(s) in the culture rather than utilization of the sulfur from the shale for growth. Future studies will determine whether this consortium is needed for sulfur removal or if a single culture is involved.

Next quarter, tests are planned to determine the effect of autoclaving the shale sample before incubation on sulfur and nitrogen reduction. Also, the ability of IGTS7, IGTS8, the OSU cultures, and Sulfolobus will be examined for removing nitrogen and sulfur from shale.

\section{Subtask 3,5. Restricted Pipe Discharge System}

The objective of this subtask was to determine the feasibility of using the restricted pipe discharge system (RPDS) for discharging spent shale from a pressurized fluidized-bed shale retort.

This subtask has been completed. Detalls of the experimental equipment, procedures and results were presented in the quarterly report for the period April through June 1989.

\section{Task 4. Beneficiation Research}

The objective of this task is to test several novel and advanced grinding and beneficiation concepts, which have shown promising results with coal, for processing Eastern oil shales. This task is divided into three subtasks: Grinding Studies, Kerogen/Mineral Separation, and Waste Treatment and Disposal Studies. 


\section{Discussion}

This task is being carried out by the Mineral Resources Institute (MRI) of the University of Alabama. One subtask of this program is being conducted by the University of Pittsburgh (UP) as a subcontractor to MRI. A second subtask has been subcontracted to the University of Nevada, Reno (UN). The activities undertaken during the quarter are described below.

\section{Subtask 4.1 Grinding Studies}

\section{Subtask $4,1,2$. Pressure Cycling Comminution}

The objective of this task is to determine the effects of operating conditions on the pressure cycling comminution (PCC) characteristics of Eastern shales. The work is being conducted by the UN.

During the quarter, UN initiated tests in the 1-gallon capacity highpressure PCC apparatus with an $8 \times 10 \mathrm{~mm}$ sample of Indiana shale. Before the test, the sample was wet screened several times to remove any entrapped fines. The sample was charged to the reactor, the pressure was increased to 5000 psig, held at pressure for 10 minutes, and then the pressure was released. Pressurizing the unit to 5000 psig requires about 250 seconds; depressurization, about $10 \mathrm{milliseconds.}$

The results showed that rapid depressurization caused some surficial breakage of the particles. After the fines (-100 mesh) were removed, the remaining sample was ground for 1 minute in a Bond mill. The size distribution of the ground product was determined using conventional wet screening techniques and compared with the controlled grinding tests conducted without pressure treatment. The results showed that pressure treatment not only produced initial breakage of the particles, it also improved grinding efficiency considerably in the coarse size range.

UN also tested the effect of using hardness reducers, such as sodium chloride and sodium hexametaphosphate, on the PCC characteristics of shale. In these tests, samples of shale ( $/ r_{-i n c h}$ maximum size) were pretreated by being immersed in each of the hardness reducers for 24 hours. The concentration of the hardness reducer was maintained at $0.1 \mathrm{M}$ during the pretreatment. After being removed from the solution, the sample was placed into the PCC apparatus. The confining pressure was increased to $4300 \mathrm{psig}$, maintained for 5 minutes, and then the pressure was released. The pressure cycle was then repeated. Observation of the treated samples showed that the hardness reducers increased the surface fracture and enhanced the permeability of the sample. Also, subsequent grinding tests with the treated sample indicated enhanced breakage of the particles. Additional tests are in progress.

\section{Subtask 4,1,3. Stirred Ball Mill Grinding}

The Netzsch mill was repaired and was put into operation on September 15, using the pin device (the John option). Table 4-1 shows the summary of results obtained in these preliminary experiments. The first series of tests (Series $P$ ) were conducted with Indiana shale prepared by grinding in a rod 
Table 4-1. THE EFFECTS OF OPERATING CONDITIONS ON THE RESULTS OF TESTS CONDUCTED IN THE STIRRED BALL MILL WITH INDIANA SHALE

\begin{tabular}{|c|c|c|c|c|c|c|c|c|c|}
\hline Sample & $\begin{array}{l}\text { Media } \\
\text { Fil1 } \\
8\end{array}$ & $\begin{array}{l}\text { Slurry } \\
\text { Solids } \\
\text { wt } 8\end{array}$ & $\begin{array}{l}\text { Slurry } \\
\frac{\text { Density }}{g / m L}\end{array}$ & $\begin{array}{l}\text { Feed } \\
\text { Rate } \\
\mathrm{mL} / \mathrm{min}\end{array}$ & $\begin{array}{l}\text { Rotor } \\
\text { Speed } \\
\text { rpm }\end{array}$ & $\begin{array}{c}\text { Net } \\
\text { Power } \\
\text { Watts }\end{array}$ & $\begin{array}{l}\text { Specific } \\
\text { Energy } \\
\mathrm{kWh} / \mathrm{kg}\end{array}$ & \multicolumn{2}{|c|}{$\frac{\text { Product Size }}{\frac{\mathrm{d}_{50}}{--} \frac{\mathrm{d}_{90}}{\text { microns }}}$} \\
\hline Feed & & & & & & & & 14.2 & 51.0 \\
\hline P1 & 80 & 33.0 & 1.23 & 430 & 1400 & 1700 & 0.0536 & 5.7 & 16.2 \\
\hline P2 & & & & 322 & 1400 & 1700 & 0.0715 & 4.9 & 14.8 \\
\hline P3 & & & & 184 & 1400 & 1700 & 0.1252 & 4.7 & 13.7 \\
\hline Feed ${ }^{\star \star}$ & & & & & & & & 15.3 & 50.5 \\
\hline A1 & 80 & 46.1 & 1.37 & $\cdots$ & 1170 & 1296 & $\cdots$ & 6.3 & 18.9 \\
\hline A2 & & & & 540 & 1300 & 2050 & 0.0462 & 5.2 & 14.8 \\
\hline $\mathrm{A} 3$ & & & & 720 & 1500 & 3100 & 0.0524 & 5.6 & 15.8 \\
\hline B1 & 80 & 43.0 & 1.33 & 150 & 1200 & 1440 & 0.1203 & 4.9 & 13.9 \\
\hline B2 & & & & 150 & 1300 & 1990 & 0.1662 & 4.0 & 11.1 \\
\hline B3 & & & & 150 & 1450 & 2980 & 0.2489 & 3.7 & 10.5 \\
\hline B4 & & & & 150 & 1500 & 3285 & 0.2744 & 3.2 & 8.1 \\
\hline $\mathrm{Cl}$ & 80 & 43.0 & 1.33 & 275 & 1200 & 1440 & 0.0664 & 5.4 & 15.4 \\
\hline $\mathrm{C} 2$ & & & & 275 & 1300 & 1800 & 0.0830 & ל ל & 12.9 \\
\hline C3 & & & & 275 & 1450 & 2750 & 0.1268 & 4.0 & 11.5 \\
\hline C4 & & & & 275 & 1500 & 3160 & 0.1457 & 3.9 & 11.4 \\
\hline D1 & 85 & 45.0 & 1.36 & 250 & 1200 & 1580 & 0.0777 & 4.9 & 13.9 \\
\hline D2 & & & & 250 & 1300 & 2080 & 0.1023 & 4.2 & 11.7 \\
\hline D3 & & & & 300 & 1450 & 2950 & 0.1202 & 3.8 & 10.9 \\
\hline D4 & & & & 300 & 1500 & 3300 & 0.1354 & 3.9 & 10.8 \\
\hline
\end{tabular}

* Void volume was $1290 \mathrm{~mL}$ for Series $\mathrm{P}, \mathrm{A}, \mathrm{B}$, and C; $1265 \mathrm{~mL}$ for Series D. Dead poiner was $1300 \mathrm{~W}$.

** This feed sample was used for Series A through $D$. 
mill at 408 solids for 30 minutes and subsequently screened to -100 mesh. The mill was operated using stainless steel media of $2 \mathrm{~mm}$ diameter at 808 loading, keeping the rotor speed at $1400 \mathrm{rpm}$. The existing feed setup and Moyno pump were used. It was found that this arrangement required a larger stock of material due to the presence of large head and lag time. Furthermore, because the pump capacity was much higher than that required for this small mill, it had to be operated on the lowest possible setting. The $d_{90}$ in the range of 13 to 16 microns was obtained due to lower solids content ( 33 wt $z$ ).

Necessary modifications in the setup were made as shown in Figure 4-1 using a peristaltic pump. This arrangement was suitable for work with the small feed rate required to achieve the desired product size ( 10 microns) in a single pass. In subsequent tests, grinding was conducted by manipulating 2 mill design variables (rotor speed and media loading) and 2 operating variables (feed rate and solids content).

Table 4-1 also lists the results of grinding tests (Series A through D), conducted to determine the effects of different operating conditions. In Series $A$, the effect of simultaneously varying feed rate and rotor speed was investigated. The results show that the specific energy values are similar and that grinding performance can be normalized in terms of operating variables.

The results of Series $A$ indicated that the feed rate was too high to achieve the required size reduction in a single pass. Therefore, in the next series of tests, experiments were conducted with a slurry solids concentration of 43 wt 8 solids and a feed rate of $150 \mathrm{~mL} / \mathrm{minute}$ at 4 different rotor speeds $(1200,1300,1450$, and $1500 \mathrm{rpm})$. The residence time for this series of tests ranged from 8 to 9 minutes. The same series of experiments was repeated (Series C) with a feed rate of $275 \mathrm{~mL} / \mathrm{min}$ (decreasing the residence time to a range of 4 to 5 minutes) to determine if the desired degree of fineness was achievable. The results of these tests indicated that increasing the feed rate from 150 to $275 \mathrm{~mL} / \mathrm{min}$ at a rotor speed of $1500 \mathrm{rpm}$ increased the $\mathrm{d}_{90}$ value from 8.1 to 11.4 microns. The overall results of the tests indicate that at 808 loading, with -100 mesh feed with a slurry concentration of 40 to 50 wt $\&$ solids, and a feed rate in the vicinity of $300 \mathrm{~mL} / \mathrm{min}$, the mill must be operated at high rotor speed $(1500 \mathrm{rpm})$ to achieve the desired fineness in a single pass.

The other mill design variable is degree of media loading. Therefore, in Series D, tests were conducted at a media loading of 858 . The operating variables were a slurry concentration of 45 wt s solids, 250 to $300 \mathrm{~mL} / \mathrm{min}$ feed rate, and rotor speeds of $1200,1300,1450$, and $1500 \mathrm{rpm}$. As expected, the increased media loading gave improved size reduction, but it also increased the specific energy. This confirms that specific energy $(k W h / t)$ is a measure of grinding efficiency.

From these results, it can be concluded that an approach to interpret energy-size reduction data is needed to avoid monitoring the level of specific operating variables. A literature research reveals that the Charles relationship, when combined with self similarity spectrum, can be a very useful tool 


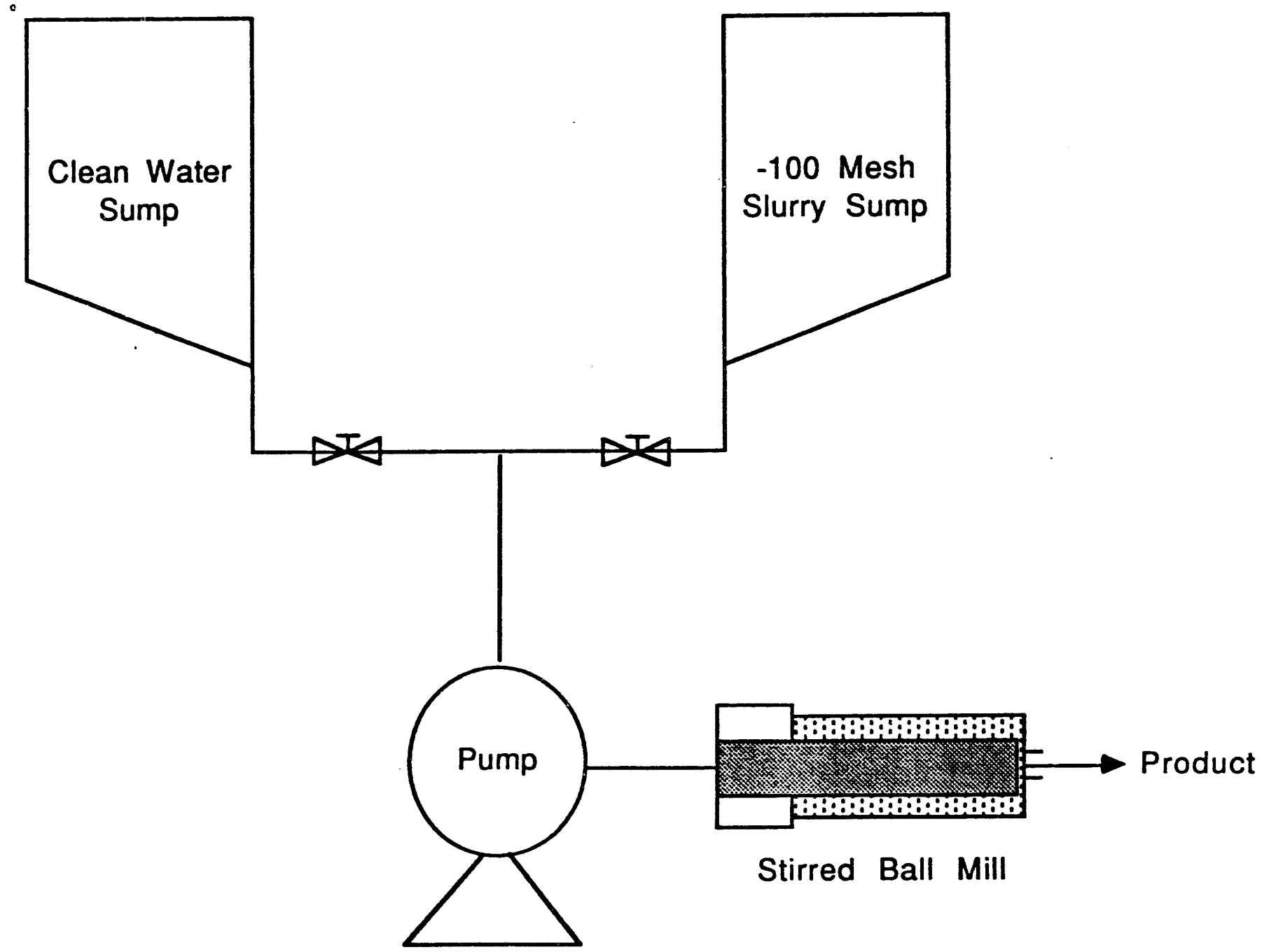

Figure 4-1. MRI STIRRED BALL MILL GRINDING SETUP 
for predicting the complete size distribution of a given shale type, which depends on only $E(\mathrm{kWh} / \mathrm{t})$ expended during grinding. In the future, tests will be conducted using a 908 media loading and coarser feed shale. Similar tests with Alabama shale are also planned to be conducted. These studies will be used to construct an empirical relationship, based on the Charles relationship and self similar spectra of these shales, for scale-up purposes.

\section{Subtask 4,1,4. Grinding Circuit Optimization}

A stainless steel batch ball mill ( 8.25 inches in diameter by 9 inches long) with 8 square lifters was built. This mill is equipped with a variable speed drive and chart-ammeter recorder assembly for measuring current used during the grinding operation. Power can be calculated using the relationship

$$
P=E I \cos q / 3 n
$$

where $E$ is voltage, $I$ is current, $q$ is the form factor, and $n$ is efficiency. A schematic of the equipment is shown in Figure 4-2.

Wet grinding tests were conducted using - 10 mesh Indiana shale at 40 wt \& solids. The calculation of ball charge material filling and mill speed was done using standard methods and are listed in Table 4-2. The feed and product size distribution were treated by the MRIEST program and the estimated breakage parameter and fitted distribution are shown in Figure 4-3. Since dry grinding tests were conducted using a batch mill at the University of Utah, direct comparisons of dry and wet grinding can not be done at present. MRI plans to conduct a series of grinding tests in their mill, the results of which can be used for comparison. Future work also includes wet grinding tests with Alabama shale.

\section{Table 4-2. CONVENTIONAL MRI BALL MILL DETAILS}

$\begin{array}{lr}\text { Mill Size, in } & 8.25 \times 9 \\ \text { Ball Filling, \& } & 50 \\ \text { Ball Load, kg } & 18.5 \\ \text { Material Filling, \& } & 100 \\ \text { Oil Shale Charge, kg } & 2.5 \\ & \\ \text { Ball Size Distribution, kg } & \\ 1.5 \text { inch } & 9.8 \\ 1.0 & 5.6 \\ 0.75 & 2.2 \\ 0.5 & 0.9 \\ \text { Mill Speed, rpm } & 77 \\ \text { Current Draw, amp } & \\ \text { No Load } & 1.2 \\ \text { Load } & 1.85\end{array}$




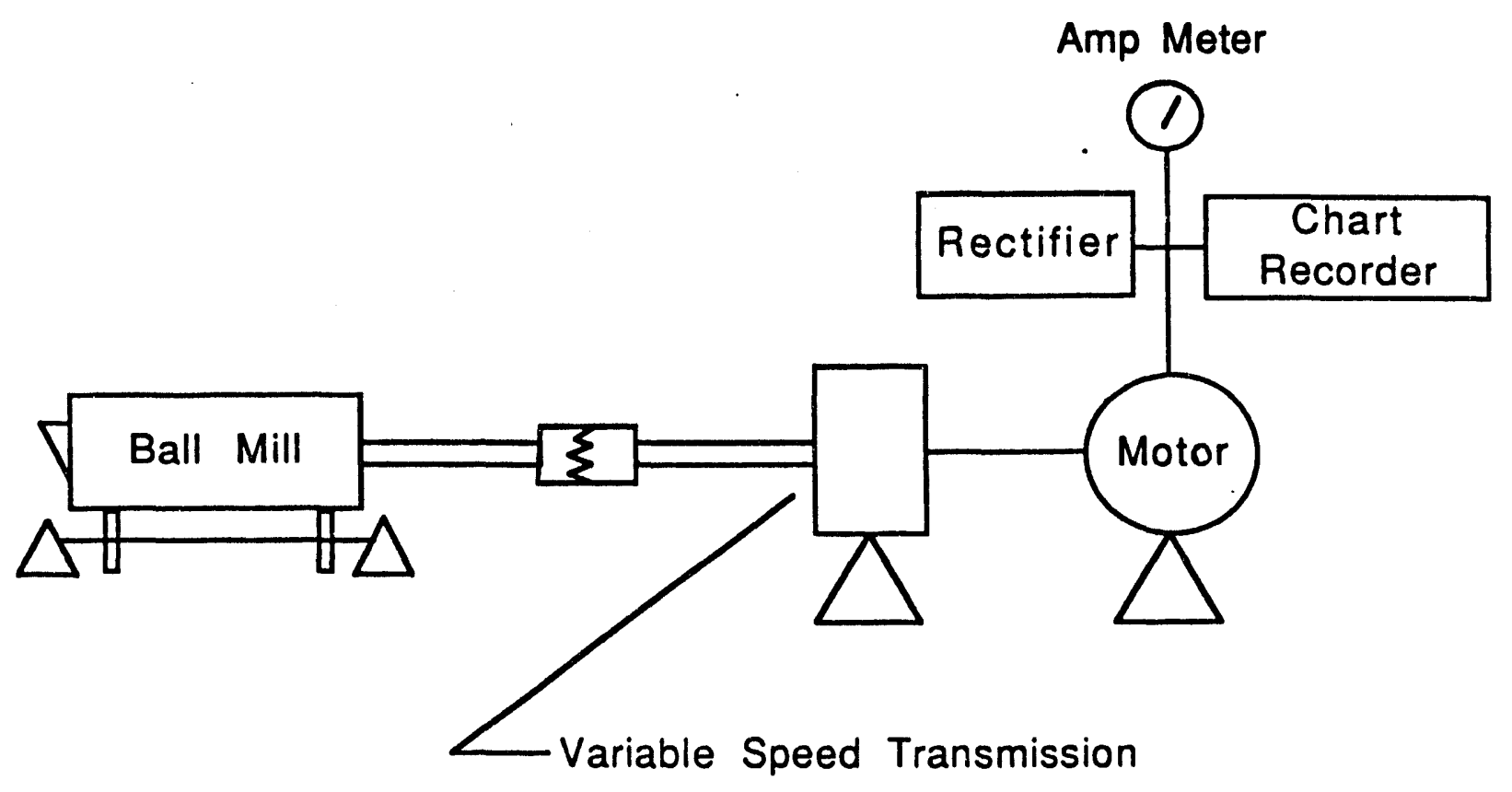

Figure 4-2. CONVENTIONAL MRI BALL MILL SETUP 


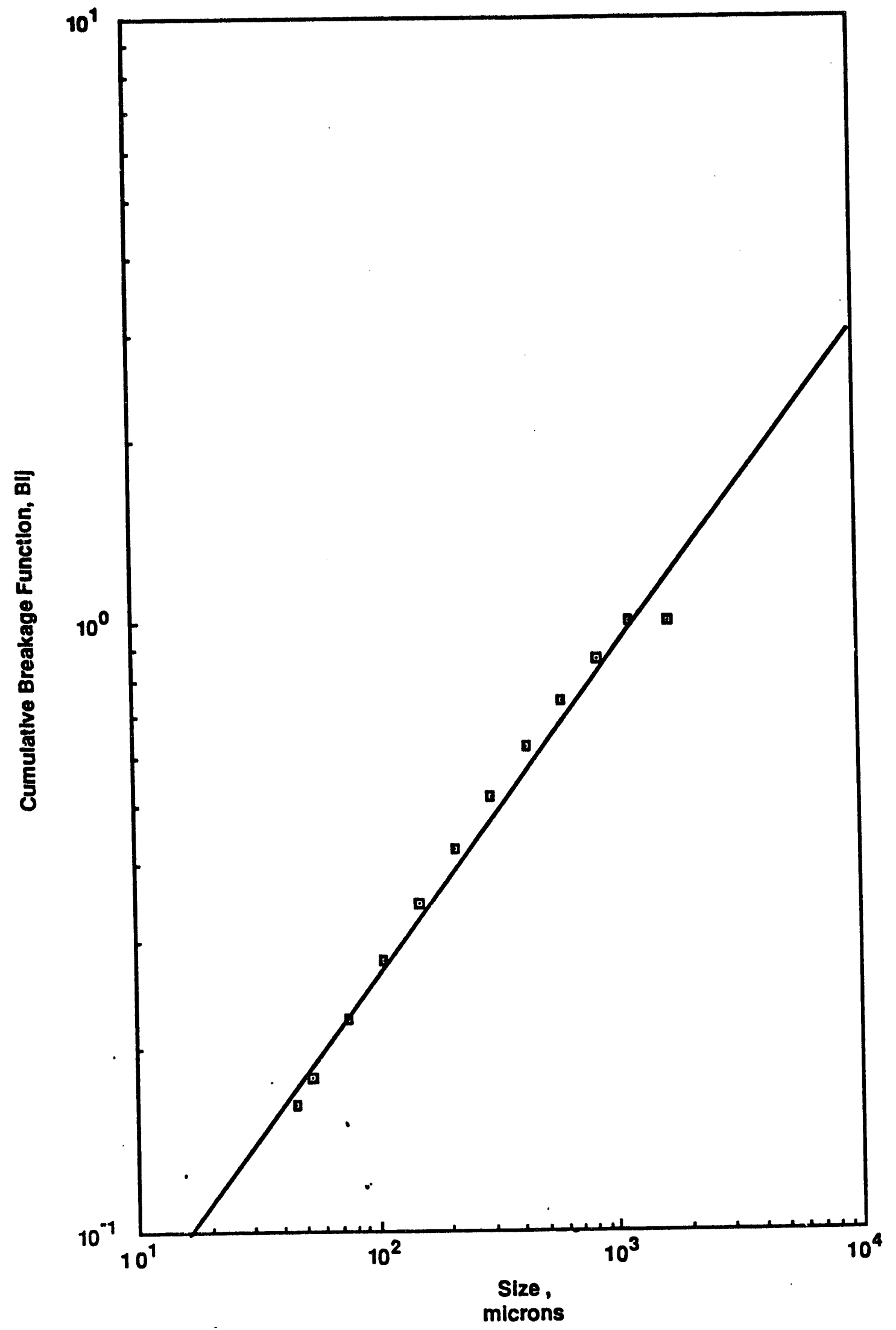

Figure 4-3. CUMULATIVE BREAKAGE FUNCTION $\left(B_{i j}\right)$ VERSUS PARTICLE SIZE ESTIMATED BY MRIEST FOR WET GRINDING OF INDIANA SHALE 


\section{Subtask 4.2. Kerogen/Mineral Matter Separation}

\section{Subtask 4,2,1. Column Flotation}

Two areas of investigation related to the column flotation of Eastern shales were completed during the quarter. In the first study, tests were conducted with a variable-height column. The effects of column height, waste water rate, feed inlet position, and air sparger pore size were measured. The data show that column height is the dominant parameter. The effects of the other variables tested diminish as the column height is increased. The tests were performed on a sample of Alabama shale, which had been ground to 908 less than 12.4 microns.

The second area of investigation was a comparison of the flotation response of 4 shales in column cells and in mechanical flotation cells. The samples were from Kentucky, Michigan, Ohio, and Tennessee. The samples were prepared by a standardized grinding procedure that also indicates the relative grindability of the 4 materials. Each sample was ground for 30 minutes in a laboratory rod mill then transferred to a stirred ball mill for an additional 60 minutes of grinding. The $d_{50}$ and $d_{90}$ values for the rod and ball $\mathrm{mill}$ products are presented in Table 4-3.

Table 4-3. GRINDING PRODUCT SIZES FOR 4 EASTERN SHALES

\begin{tabular}{|c|c|c|c|c|}
\hline \multirow[t]{2}{*}{ Sample } & \multicolumn{2}{|c|}{ Rod Mill } & \multicolumn{2}{|c|}{ Stirred Ball Mill } \\
\hline & $d_{50}$ & $\mathrm{~d}_{90}$ & $\mathrm{~d}_{50}$ & $\mathrm{~d}_{90}$ \\
\hline & & & & \\
\hline $\begin{array}{l}\text { Ohio } \\
\text { Kentucky }\end{array}$ & $\begin{array}{l}12.5 \\
15.1\end{array}$ & $\begin{array}{l}39.0 \\
46.8\end{array}$ & $\begin{array}{l}4.1 \\
4.8\end{array}$ & $\begin{array}{l}10.6 \\
12.1\end{array}$ \\
\hline Michigan & 12.2 & 38.0 & 4.2 & 11.3 \\
\hline Tennessee & 15.8 & 49.3 & 4.3 & 11.2 \\
\hline
\end{tabular}

Mechanical cell flotation was performed on a $500-\mathrm{g}$ sample of ground shale. Flotation was done at approximately 10 wt 8 solids in the rougher stage with a frother dose of $1.6 \mathrm{lb} / \mathrm{ton}$. The froth product was repulped and refloated through 5 stages of cleaner flotation. Column flotation was carried out using the MRI standard continuous flotation procedure. The tests were performed in the 43 -inch column with the feed location at 25 inches and the pulp-froth interface at 14 inches. Grade recovery curves were obtained at frother doses of 45 and $30 \mathrm{ppm}$ ( 2.6 and $1.8 \mathrm{lb} /$ ton).

The results of the mechanical and column flotation tests are shown in Figures 4-4 through 4-9. These data show that in all cases, except Kentucky shale, superior results were obtained with the column cell. Further optimization of column cell parameters for each specific shale is required. The data also show that the Michigan shale responded best to flotation and the Ohio shale, even though it was the most finely ground, responded worst. These data indicate a significant variation in the liberation characteristics of the 4 shales tested. 


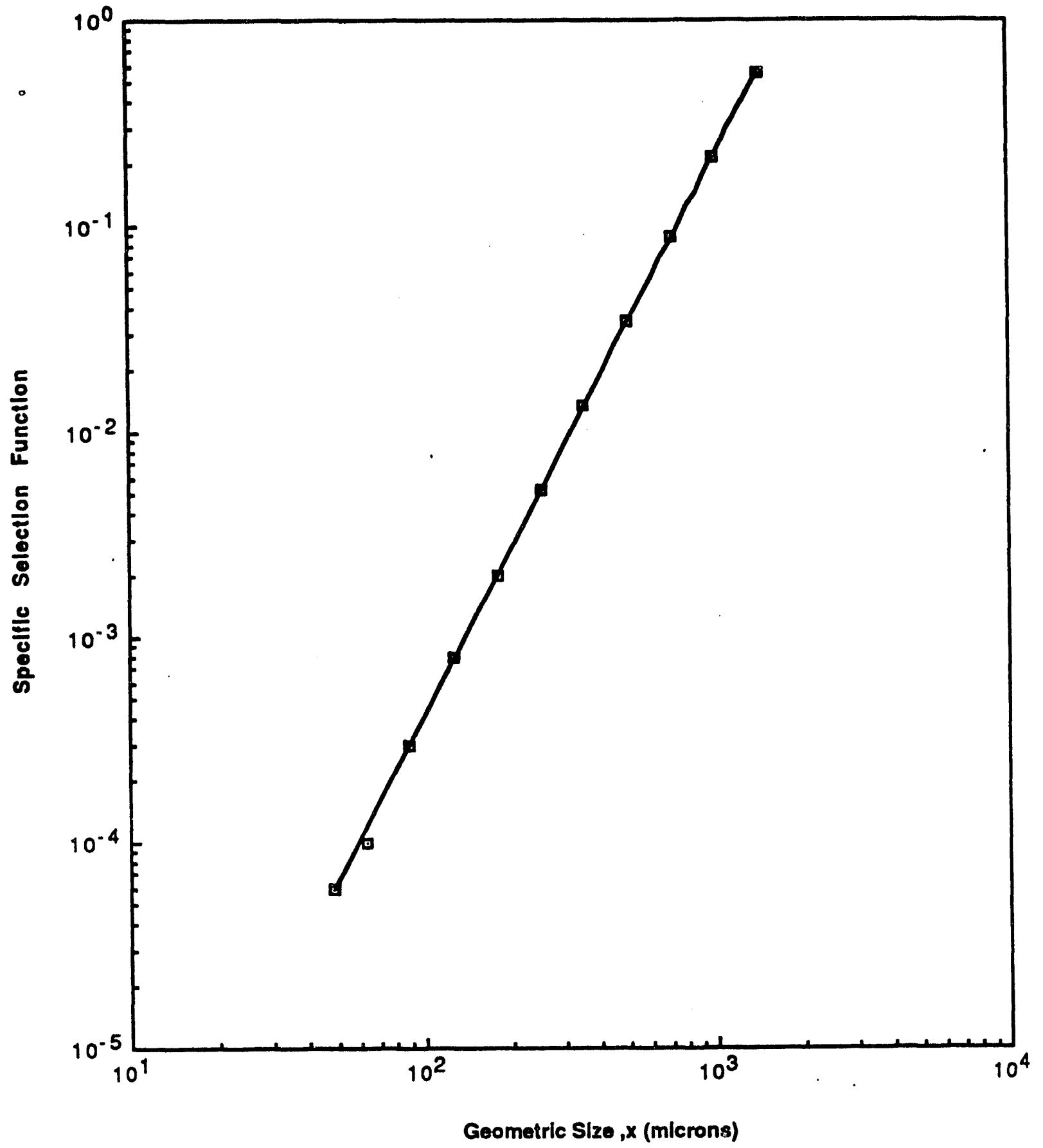

Figure 4-4. SPECIFIC SELECTION FUNCTION ( ${ }^{\mathrm{E}}{ }^{\mathrm{E}}$ ) VERSUS PARTICLE SIZE $(x)$ ESTIMATED BY MRIEST FIT FOR WET (408) GRINDING OF INDIANA SHALE 


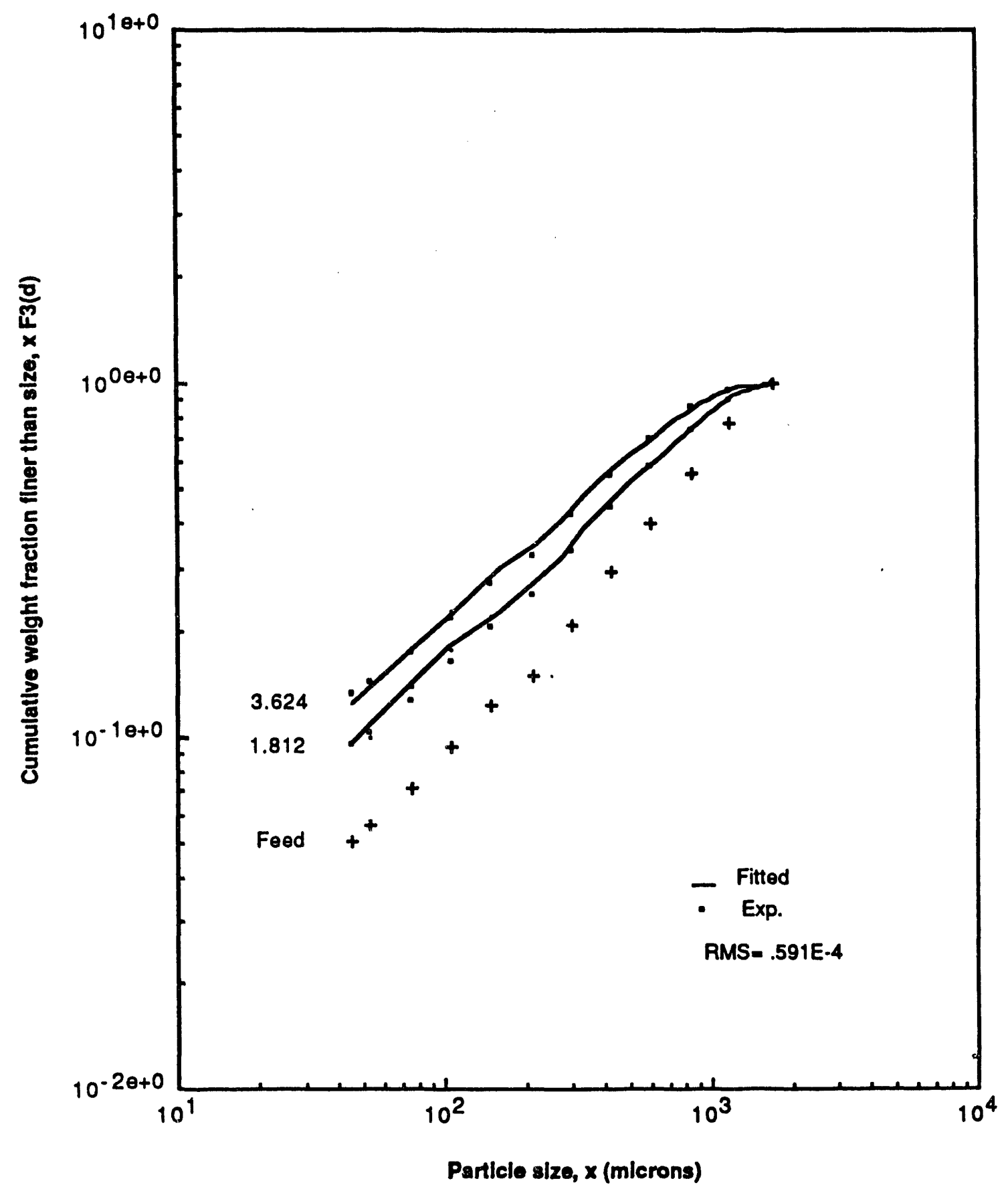

Figure 4-5. COMPARISON OF EXPERIMENTAL PRODUCT SIZE DISTRIBUTIONS AND LINEAR MODEL FIT FOR WET GRINDING OF INDIANA SHALE 


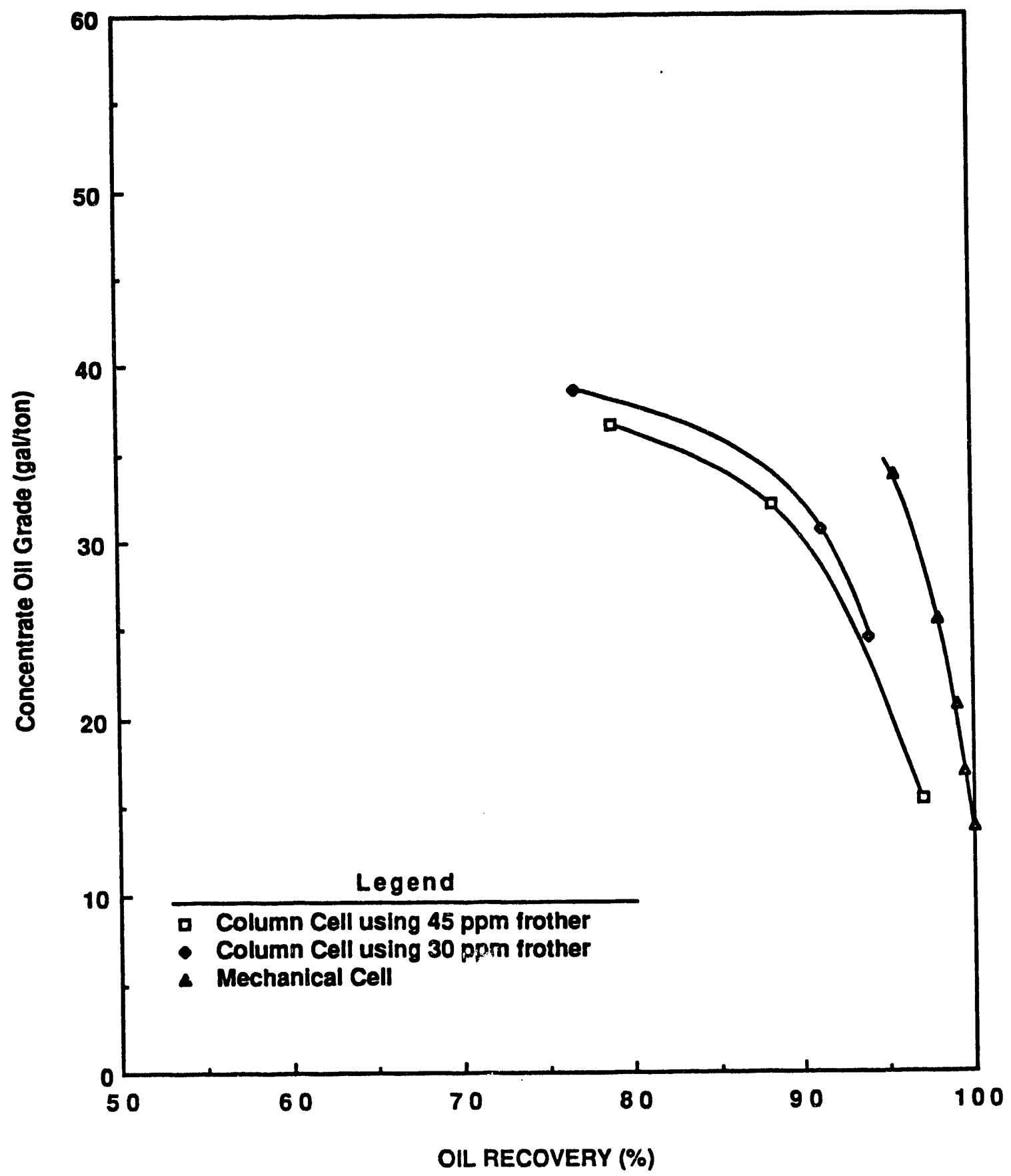

Figure 4-6. COMPARISON OF GRADE RECOVERY CURVES FOR COLUMN CELL AND MECHANICAL CELL FLOTATION FOR RENTUCKY OIL SHALE 


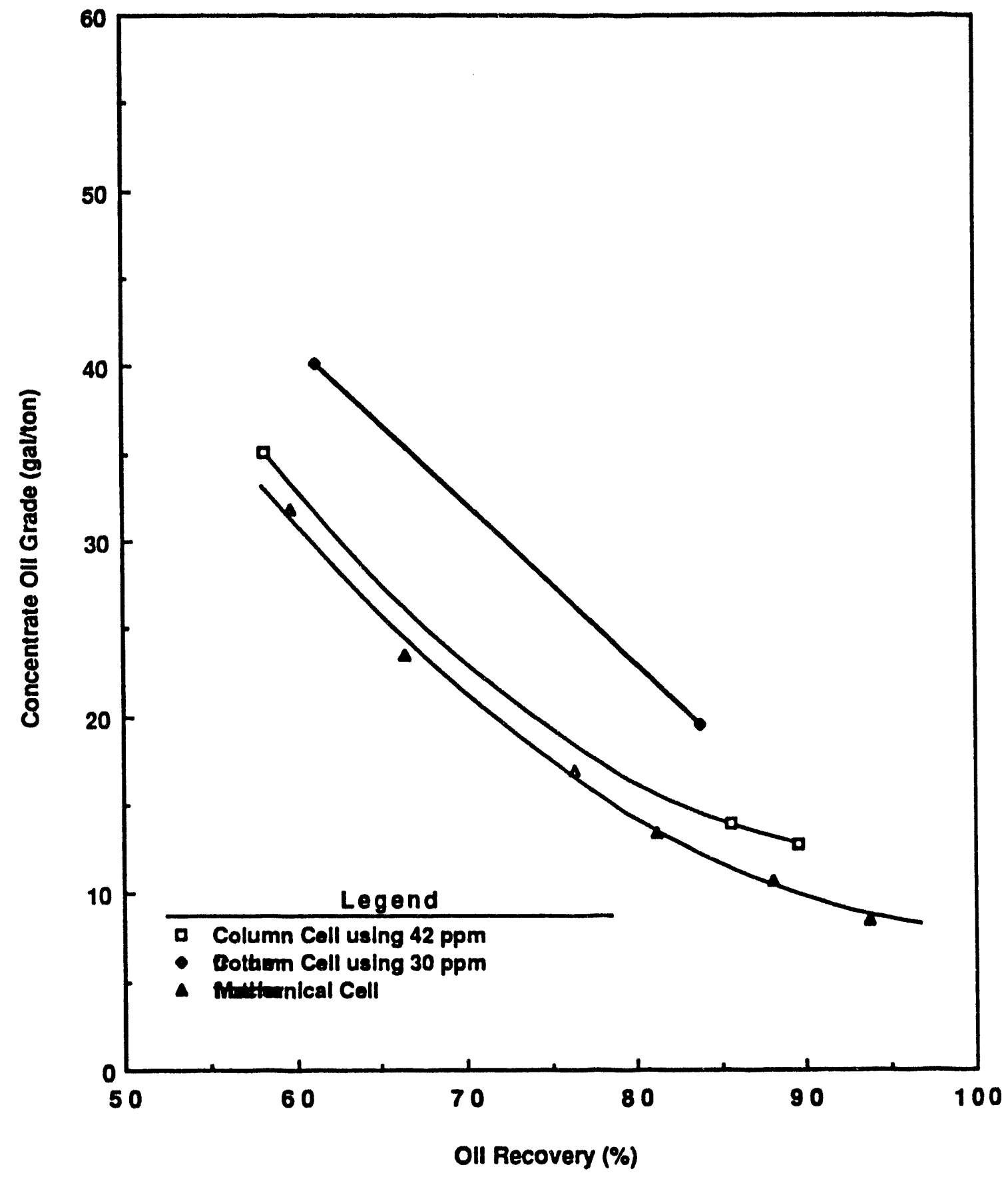

Figure 4-7. COMPARISON OF GRADE RECOVERY CURVES FOR COLUMN CELL AND MECHANICAL CELL FLOTATION FOR OHIO OIL SHALE 


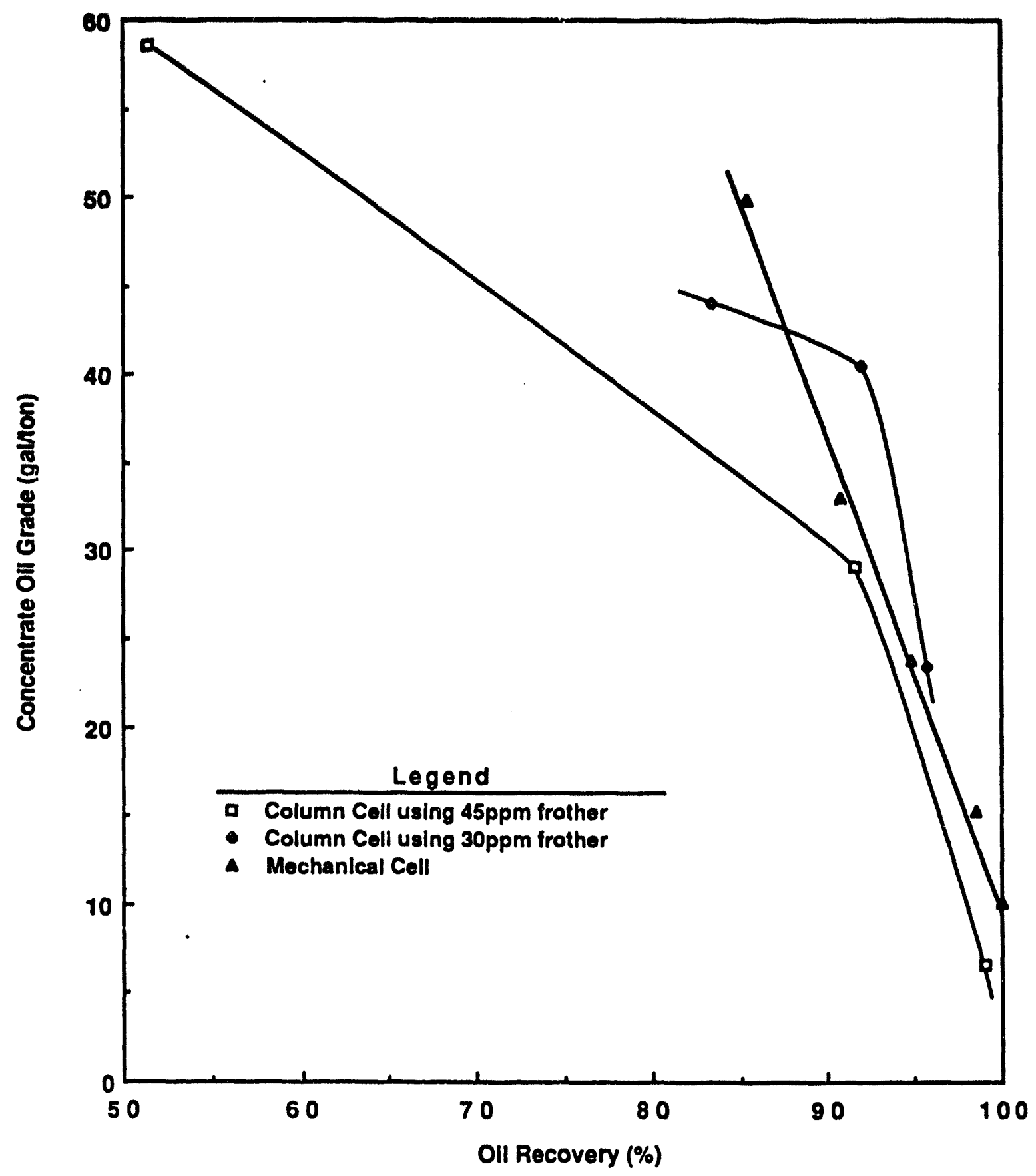

Figure 4-8. COMPARISON OF GRADE RECOVERY CURVES FOR COLUMN CELL AND MECHANICAL CELL FLOTATION FOR MICHIGAN OIL SHALE 


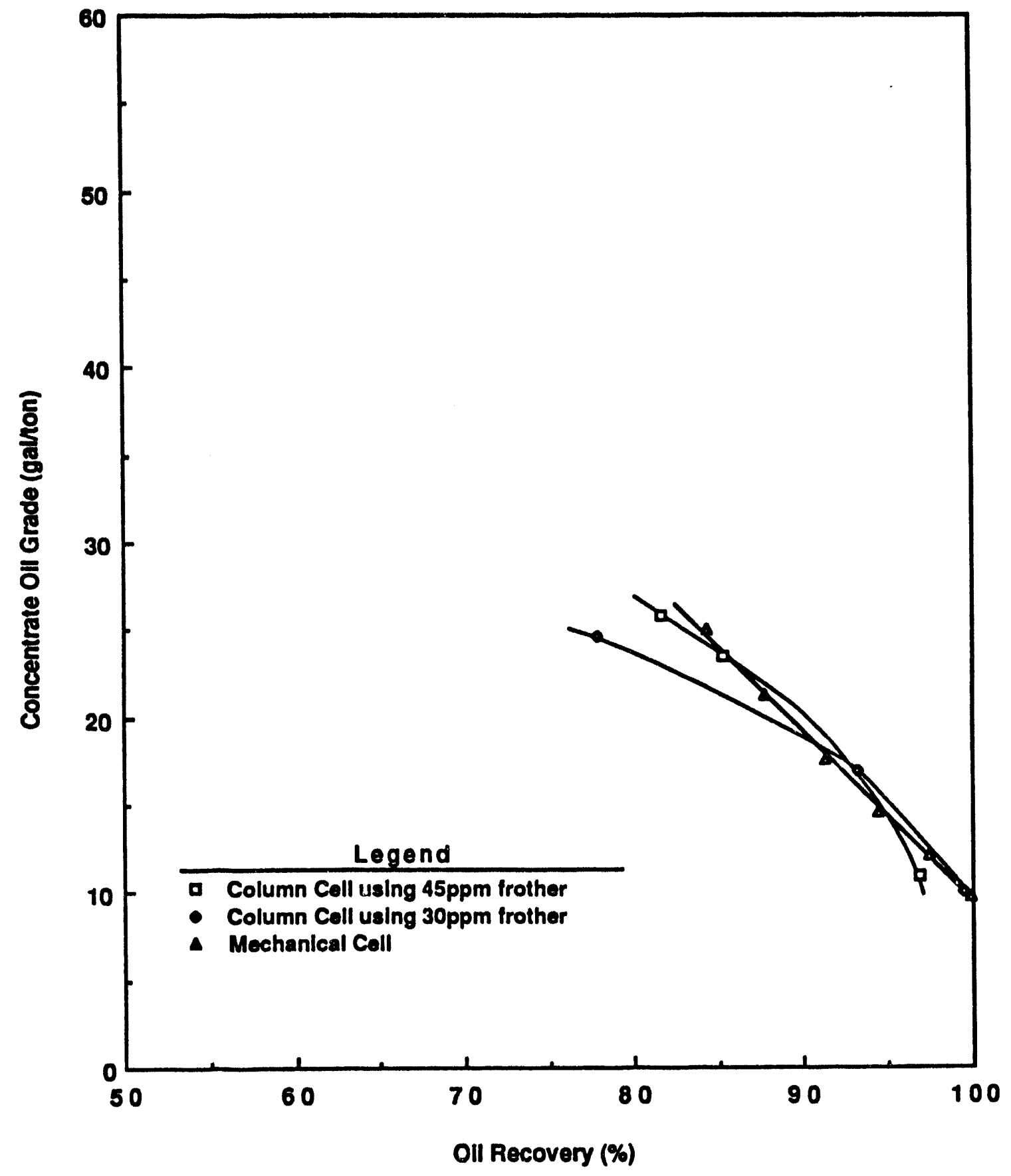

Figure 4-9. COMPARISON OF GRADE RECOVERY CURVES FOR COLUMN CELL AND MECHANICAL CELL FLOTATION FOR TENNESSEE OIL SHALE 


\section{Subtask 4.2.2. Alr-Sparged Hydrocyclone}

Because the results of tests conducted previously with the air-sparged hydrocyclone have not been encouraging, MRI has decided to discontinue testing of the unit. Efforts will be concentrated on the grinding tasks.

\section{Subtask $4,2,3$. LICADO Process}

The LICADO process is a surface property-based technique to separate mineral matter from kerogen. It relies on the relative wettability of kerogen and the ash components of shale with liquid carbon dioxide $\left(\mathrm{CO}_{2}\right)$ and water, respectively. When 1 iquid $\mathrm{CO}_{2}$ is dispersed into a shale/water slurry, it tends to form agglomerates with the o1l-rich particles and float them into the liquid $\mathrm{CO}_{2}$ phase, while the ofl-lean components remain in the aqueous phase as refuse. The objective of this subtask is to establish proper operating conditions for the different process parameters to be considered in various experimental studies.

During the quarter, UP researchers conducted 3 types of experiments with finely ground Indiana shale: 1) screen-type agglomeration tests in the batch research unit (BRU), 2) semi-continuous tests in the 4-inch research development unit (RDU), and 3 ) batch tests in the $3 R U$.

The use of 2 dispersants (1- and 2-octanol) was investigated during the quarter. The physical properties of these chemicals have been described previously. The dispersant was introduced at the desired dose in a 2 wt 8 slurry of shale in water. The solution was then preconditioned by vigorous agitation for at least 1 hour prior to conducting the tests. The density of the shale was determined to be $2.30 \mathrm{~g} / \mathrm{cm}^{3}$. The correlations for Fischer Assay (developed by MRI) were used to calculate the Fischer Assay for the feed and upgraded shale product. The average Fischer Assay of the feed material was calculated to be $12.0 \mathrm{GPT}$. The ash content was 78.18. The oil yield for the " oduct was determined from the following relationship:

$$
011 \text { Yield (wt } 8)-(\text { Product Yield, wt } 8) * \begin{array}{r}
\left(011 \text { Content }_{\text {product }}\right) \\
\left(011 \text { Content }_{\text {feed }}\right)
\end{array}
$$

Screen-type agglomeration tests were conducted with Indiana shale at various doses of 1 - and 2-octanol. The product was recovered on a -80 mesh screen installed inside the ball valve of the BRU. The procedure and initial results were presented in the previous quarterly report (DOE/MC/11089-22 for the period April through June 1989). The concentration range for the 2 reagents was extended to $1000 \mathrm{ppm}$. The Fischer Assays and the oil yields calculated for the 2 reagents are shown in Figures $4-10$ and 4-11. The scatter in the data indicate that additional experiments are necessary to calculate the standard deviation at each dose, particularly for 1-octanol. However, it is clear that a significant improvement in both the recovery and the product quality was achieved by using the 2 dispersants at doses exceeding $300 \mathrm{ppm}$. The Fischer Assay was improved to values exceeding $30 \mathrm{GPT}$ with $500 \mathrm{ppm}$ of 1 octanol with an ofl yield of nearly 708 . The differences in the behavior of the 2 alcohols might be related to their different solubilities in water. The 


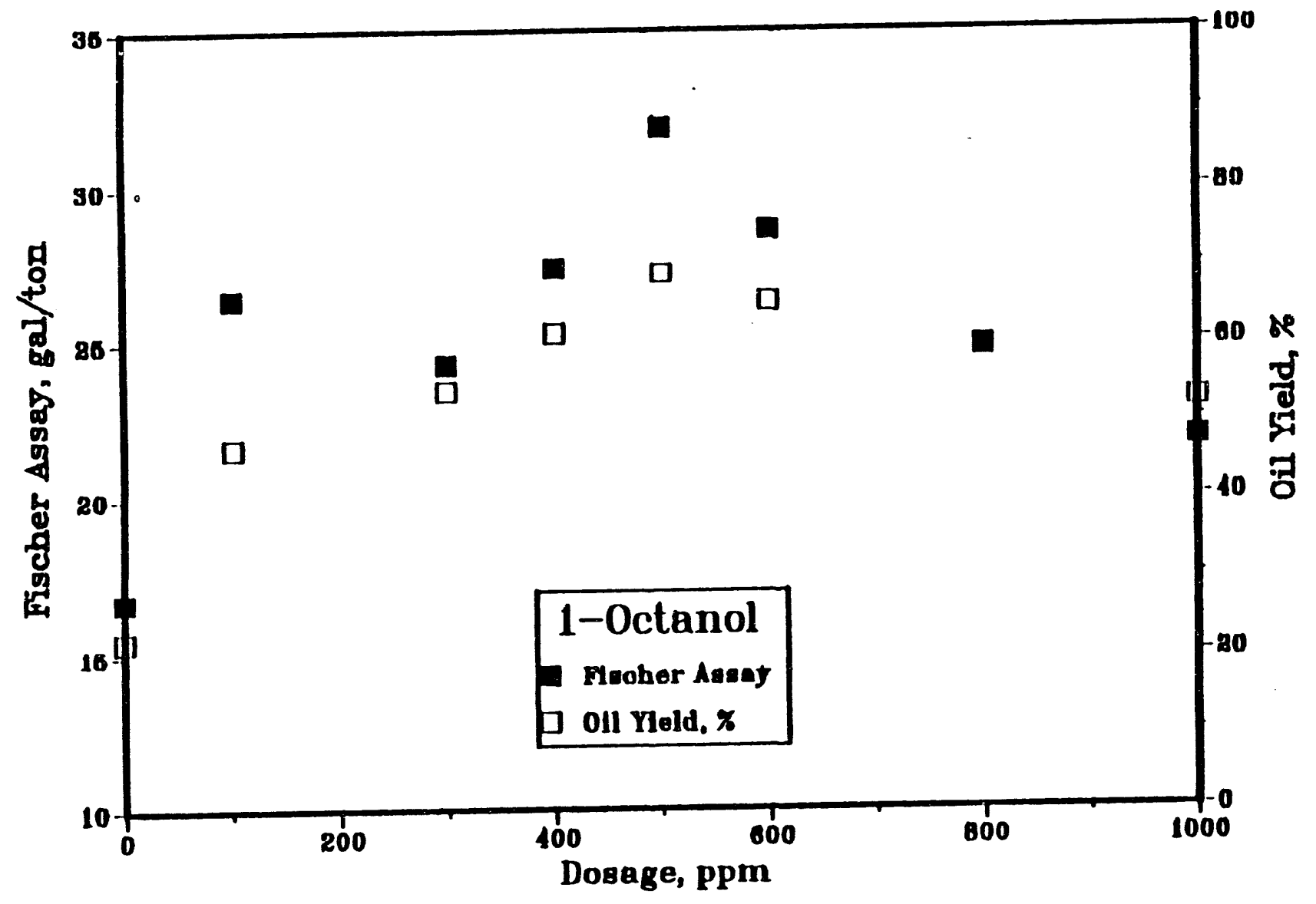

Figure 4-10. EFFECT OF 1-OCTANOL FOR INDIANA OIL SHALE 


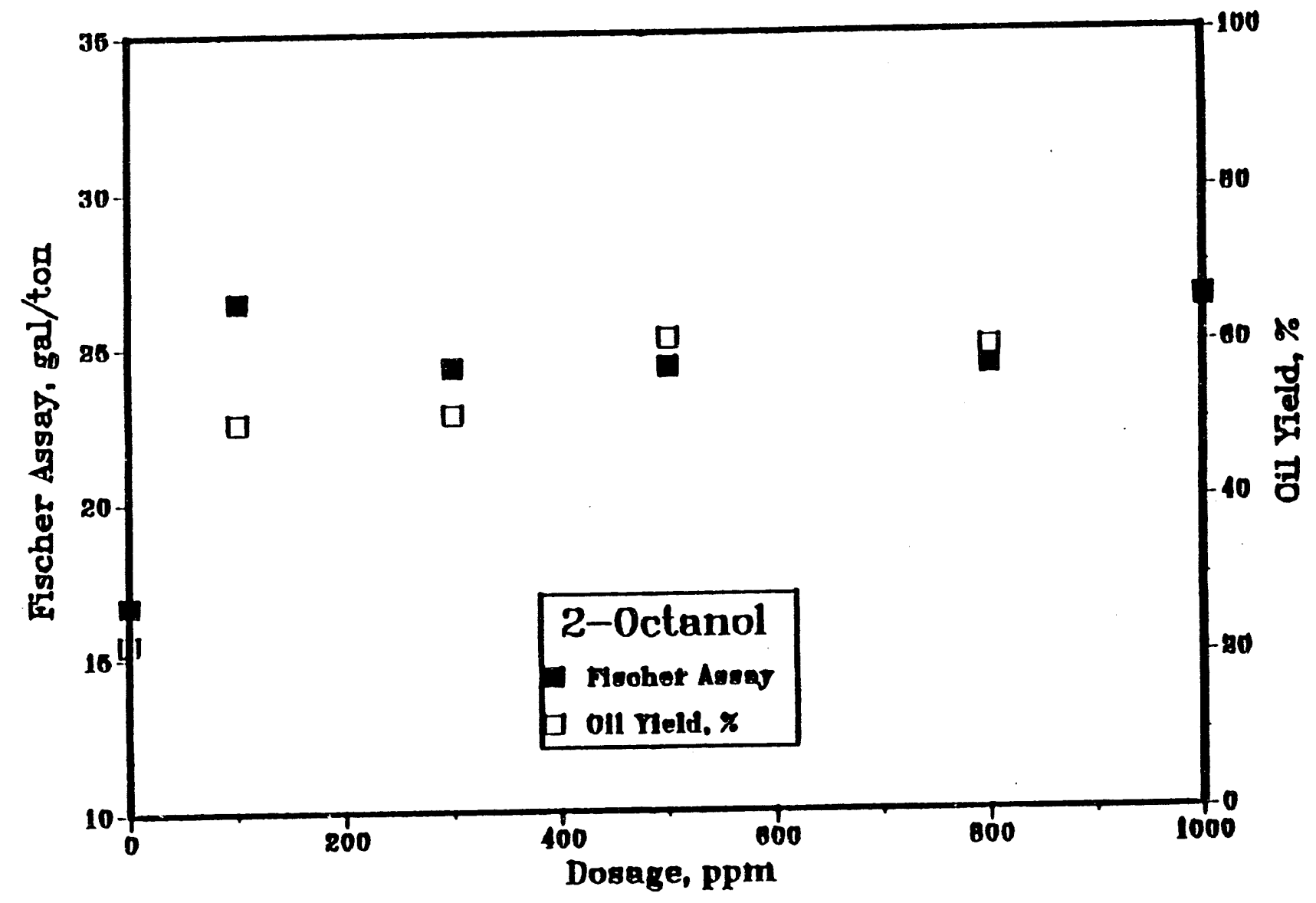

Figure 4-11. EFFECT OF 2-OCTANOL FOR INDIANA OIL SHALE 
solubility of 1-octanol at room temperature is $440 \mathrm{ppm}$; that of 2 -octanol is $790 \mathrm{ppm}$. These reagents not only appear to act as co-agglomeration agents by increasing the experimentai yield, but also enhance the dispersion of the mineral matter, as evidenced by improved product quality.

The RDU (Figure 4-12) was designed to conduct beneficiation tests in semi-continuous mode, and also to study the hydrodynamic characteristics of a shale-water-1iquid $\mathrm{CO}_{2}$ system in a 4-inch diameter stirred column. Prior to conducting the experiment, the slurry of shale is premixed with liquid $\mathrm{CO}_{2}$ for a 5 to 10 -minute period at a high agitation rate (usually $>2000 \mathrm{rpm}$ ). Liquid $\mathrm{CO}_{2}$ is introduced from the bottom of the separation column through a disperser at a constant flow rate for a specified contact time and carries the upgraded product up to a collecting cup at the top of the separation column. The upgraded product with liquid $\mathrm{CO}_{2}$ flows down to a product sampler where the Ifquid $\mathrm{CO}_{2}$ leaves the system through a back-pressure valve. Refuse samples are withdrawn from the bottom of the cell to a sampler at the termination of each experiment. The pressure, temperature, and flow rate are monitored from an instrument panel adjacent to the apparatus.

Preliminary tests were performed using the RDU for a premixing time of 7 minutes. The slurry concentration was maintained in the range of 2 to 3 wt 8 solids. The liquid $\mathrm{CO}_{2}$ flow rate was fixed at $500 \mathrm{~mL} / \mathrm{min}$ for a contact time of 15 minutes. The speed of agitation subsequent to the premixing operation was increased from $1000 \mathrm{rpm}$ to $2050 \mathrm{rpm}$. The results showed that a negligible amount of upgraded product was being collected at the agitation speed of 1000 $\mathrm{rpm}$. Consequently, a minimum speed of $1700 \mathrm{rpm}$ was necessary to achieve proper dispersion of the liquid $\mathrm{CO}_{2}$ droplets to improve contact with the kerogenrich material. Tests were also conducted in the presence of 1-octanol. The initial results are presented in Table 4-4.

Table 4-4. SEMI-CONTINUOUS TESTS IN THE RDU WITH INDIANA SHALE

\begin{tabular}{|c|c|c|c|c|c|c|c|}
\hline $\begin{array}{c}\text { Speed, } \\
\text { rpm }\end{array}$ & $\begin{array}{c}\text { Dosage, } \\
\text { ppm }\end{array}$ & $\begin{array}{l}\text { Yield, } \\
\text { wt \& } \\
\end{array}$ & $\begin{array}{l}\text { Product } \\
\text { Density, } \\
\mathrm{mL} / \mathrm{min}\end{array}$ & $\begin{array}{l}\text { Product } \\
\text { Ash. wt } 8\end{array}$ & $\begin{array}{c}\text { Fischer } \\
\text { Assay, } \\
\text { GPT } \\
\end{array}$ & $\begin{array}{l}\text { Carbon, } \\
\text { wt } 8\end{array}$ & $\begin{array}{c}\text { Oil } \\
\text { Recovery } \\
\text { wt } 8 \\
\end{array}$ \\
\hline 1800 & 0 & 17.5 & 2.06 & 70.1 & 22.8 & 22.4 & 31.6 \\
\hline 1700 & 500 & 14.8 & 2.00 & 66.5 & 25.9 & 24.9 & 30.4 \\
\hline 1700 & 1000 & 23.8 & 2.03 & 68.6 & 24.3 & 23.5 & 45.8 \\
\hline 2050 & 500 & 40.5 & 2.12 & 73.6 & 19.7 & 19.8 & 63.3 \\
\hline
\end{tabular}

The results show that agitation speed significantly affects the yield and separation characteristics. A significant improvement in the oil recovery was obtained at the high mixing speed of $2050 \mathrm{rpm}$. However, this was accompanied by a decrease in the Fischer Assay of the product, suggesting that mineral matter was being entrapped in the agglomerates of the upgraded material with liquid $\mathrm{CO}_{2}$. Additional experiments will be carried out before any firm conclusions can be drawn. The RDU is currently being modified to incorporate multi-stage cleaning for the same feed material. Improved product quality and higher yields are anticipated in the near future. The RDU will also be utilized to carry out semi-continuous tests with shales of different particle sizes. 


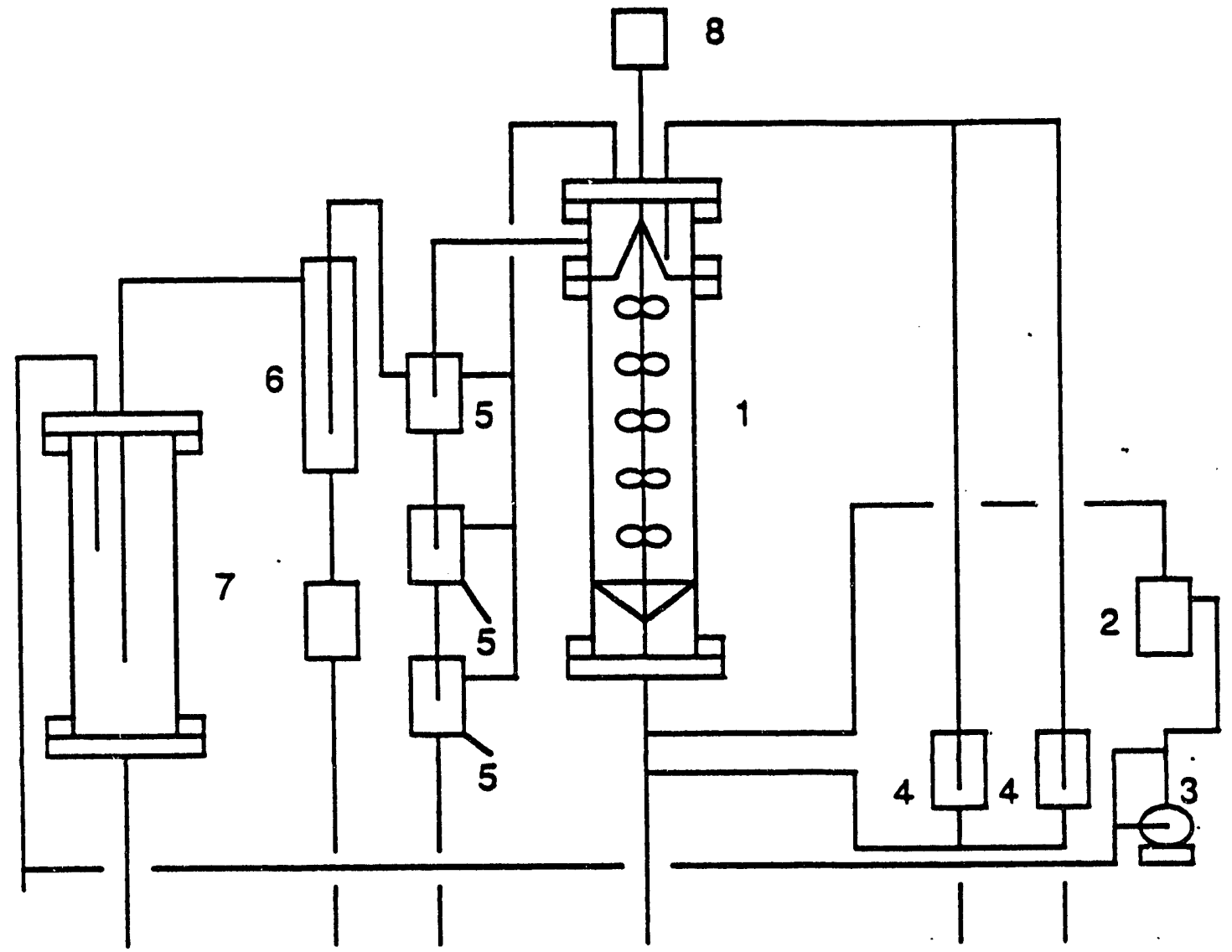

1 column

2 flowmeter

$3 \quad \mathrm{CO} 2$ pump

4 refuse collector
5 product collector

6 settling tank

$7 \quad$ CO2 tank

8 motor

Figure 4-12. RESEARCH DEVELOPMENT UNIT (RDU) 
In addition to the screen-type agglomeration experiments, the 2 -inch BRU was used to carry out batch experiments in which the screen that was inserted in the ball valve was removed. The procedure for the batch experiments was the same as that used previously. While the screen agglomeration technique relies on the agglomeration ability of the liquid $\mathrm{CO}_{2}$ for the kerogen-rich material, the batch tests also incorporate the transport of the upgraded material into the liquid $\mathrm{CO}_{2}$ phase. Beneficiation tests were conducted with $900 \mathrm{~mL}$ of a 5 wt $z$ solids slurry of Indiana shale in water. The slurry was premixed with liquid $\mathrm{CO}_{2}$ for 1 minute at $800 \mathrm{rpm}$. The concentration of 1 octanol was varied from 0 to $1000 \mathrm{ppm}$ and duplicate tests were conducted under the same conditions. The results were reproducible within 58 to 108 for both yield and Fischer Assay of the product. The experiments were conducted at an agitation speed of $800 \mathrm{rpm}$ in both the upper and lower high-pressure vessels. The flow rate of liquid $\mathrm{CO}_{2}$ was fixed at $250 \mathrm{~mL} / \mathrm{min}$ for a contact time of 2.5 minutes. To minimize sedimentation effects, a small contact time was chosen and the settling period after contact with liquid $\mathrm{CO}_{2}$ was eliminated. The results are shown in Table 4-5.

Table 4-5. RESULTS OF BATCH LICADO TESTS WITH INDIANA SHALE

\begin{tabular}{|c|c|c|c|c|c|c|c|}
\hline $\begin{array}{l}\text { Test } \\
\text { No. } \\
\end{array}$ & $\begin{array}{c}\text { Dosage, } \\
\text { ppm }\end{array}$ & $\begin{array}{l}\text { Yield, } \\
\text { wt } 8 \\
\end{array}$ & $\begin{array}{l}\text { Product } \\
\text { Density, } \\
\mathrm{mL} / \mathrm{min} \\
\end{array}$ & $\begin{array}{c}\text { Product } \\
\text { Ash, wt \& }\end{array}$ & $\begin{array}{c}\text { Fischer } \\
\text { Assay, } \\
\text { GPT } \\
\end{array}$ & $\begin{array}{l}\text { Carbon, } \\
\text { wt } 8\end{array}$ & $\begin{array}{c}\text { Oil } \\
\text { Recovery, } \\
\text { wt } 8 \\
\end{array}$ \\
\hline 1 & 0 & 16.8 & 2.17 & 74.3 & 18.0 & 18.5 & 25.6 \\
\hline 2 & 100 & 24.4 & 2.11 & 72.2 & 21.3 & 21.1 & 44.0 \\
\hline 3 & 300 & 27.5 & 2.11 & 72.9 & 22.3 & 22.0 & 52.0 \\
\hline 4 & 500 & 29.8 & 1.99 & 71.3 & 27.7 & 26.4 & 70.0 \\
\hline 5 & 1000 & 32.9 & 2.02 & 71.3 & 25.7 & 24.8 & 71.6 \\
\hline
\end{tabular}

As the results show, a marked improvement in the process performance was obtained by using 1-octanol at doses exceeding $300 \mathrm{ppm}$. The Fischer Assay as well as the oil recovery was low in the absence of the reagent. A steady increase in the yield was registered as the reagent dose was increased with the maximum of 33 wt $\&$ being achieved at a dose of $1000 \mathrm{ppm}$. This lends support to the previous finding that 1-octanol could be acting as a coagglomeration agent. The quality of the product also improved and the highest value of Fischer Assay was obtained at a dose of $500 \mathrm{ppm}$. This was similar to the results obtained in the screen agglomeration tests. Oil recoveries in excess of $70 \%$ could be obtained in the batch tests by using the appropriate dose of reagent. It is proposed to conduct additional tests at different particle sizes of feed shale to optimize process performance.

\section{Subtask 4,3. Waste Treatment and Disposal Studies}

Comparative analyses of water generated during grinding studies of the 6 shale samples are shown in Table 4-6. Each 500-gram sample of shale was ground for 30 minutes at 35 wt \& solids with deionized water. The ground slurries were filtered without dilution to obtain water samples for analyses.

The water samples were diluted to 4 liters with deionized water to simulate the approximate water analyses that would be present during flotation 
Table 4-6. COMPARISON OF WATER SAMPLE ANALYSES

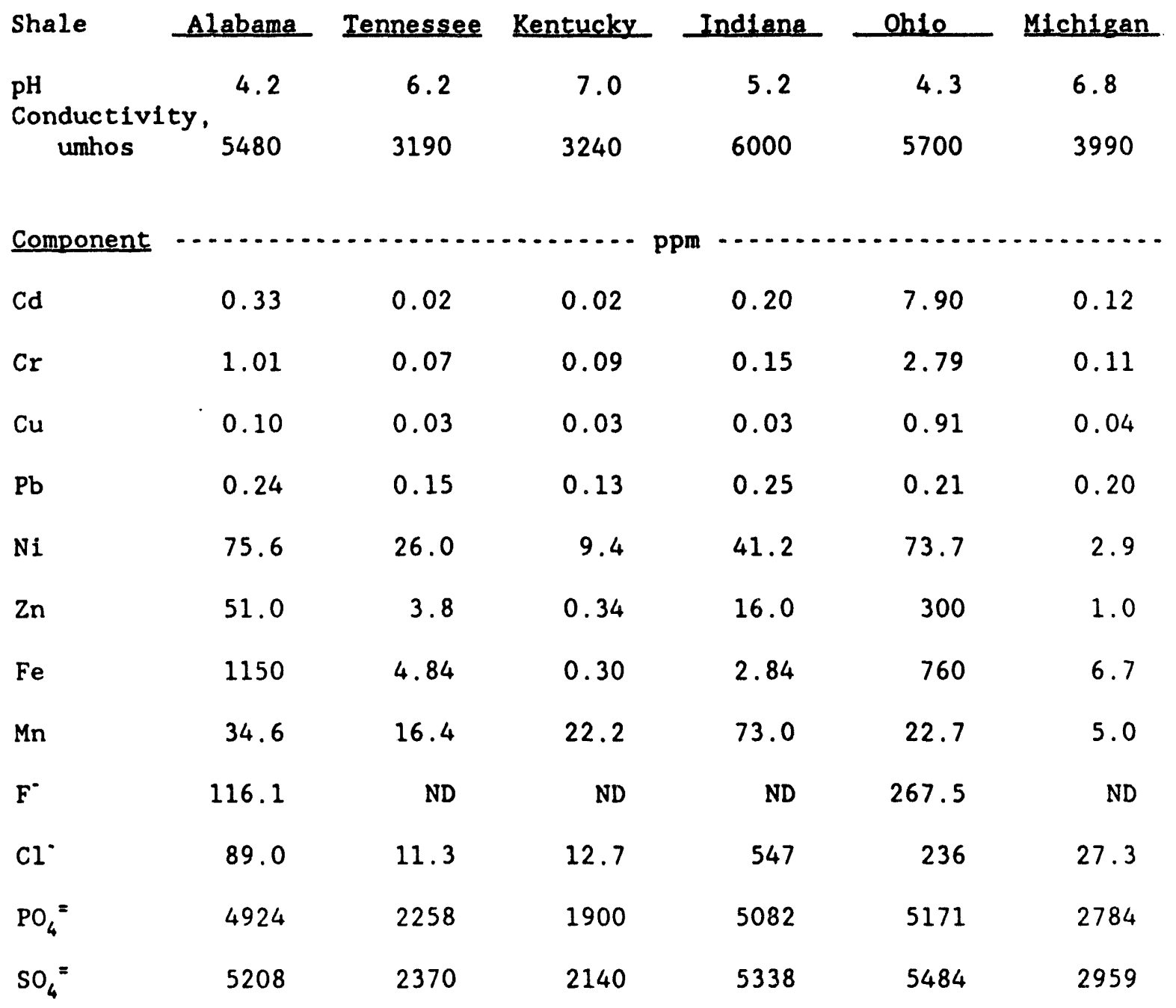


when using treated water as a diluting medium for the high-solids grinding conditions. These diluted water samples are being processed through an activated charcoal, anionic and cationic resin system to study the removal of total organic carbon compounds as well as trace and minor elements that may be considered hazardous or detrimental to the environment.

\section{Task 5. Operation of PFH on Beneficiated Shale}

The objective of this task is to modify the PFH process to facilitate its use for fine-sized, beneficiated Eastern shales. This task is divided into three subtasks: Non-Reactive Testing, Reactive Testing, and Data Analysis and Correlations.

\section{Subtask 5.1. Non-Reactive Testing}

The objective of this subtask is to determine operating conditions necessary to achieve the desired residence time of fine shale particles in a fluidized bed (or fluidized in the interstices of a packed bed of inert material). The results of Subtask 5.1 will be used to select the configuration, gas velocities and particle sizes to be used in the reactor for Subtask 5.2 (Reactive Testing).

\section{Discussion}

In Subtask 5.1 (Non-Reactive Testing), a fluidization test was conducted with the beneficiated shale received last quarter. The fluidization characteristics of this material proved to be very similar to those of the original sample. The measured minimum and complete fluidization velocities $\left(U_{m f}\right.$ and $U_{c f}$ ) were approximately 0.18 and $0.45 \mathrm{ft} / \mathrm{s}$, respeçtively.

The 1-inch-diameter fines feeder was successfully tested with a quantity of raw shale fines. Although the fines feed rate did vary with screw speed, the effective flight loading was not constant. Therefore, evaluation of various other methods for continuously feeding beneficiated shale into a highpressure fluidized-bed reactor continued. Methods being evaluated include operating the feed hopper at a higher pressure than that of the reactor and entraining material into the reactor, fluidizing the material in the feed hopper, and adding a flow conditioner to the beneficiated shale.

\section{Task 6. Environmental Data and Mitigation Analyses}

The overall objectives of Task 6 are to obtain environmental data relating to $\mathrm{PFH}$ and shale beneficiation, and also to analyze the potential . environmental impact of the integrated PFH process. This task is divided into four subtasks: Characterization of Processed Shales, Water Availability and Treatment Studies, Heavy Metals Removal, and PFH System Analyses.

\section{Subtask 6.1. Characterization of Processed Shales}

The objective of this subtask is to determine the effects of $\mathrm{PFH}$ operating conditions on the physical and chemical characteristics of spent shales produced. 
During the quarter, in Subtask 6.1.1 (Physical Properties of Processed Shales), samples of spent Kentucky, Alabama, Ohio, and Tennessee shale from the continuous PFH unit were sent for physical properties testing. The thermal conductivity ( $k$ ) of samples of raw and PFH processed Indiana shale was determined to be 0.157 and $0.168 \mathrm{Btu} / \mathrm{ft}^{2}-\mathrm{h}-{ }^{\circ} \mathrm{F}$, respectively. For comparison, the thermal conductivity of a sample of dry sand was determined by the same procedure to be $0.926 \mathrm{Btu} / \mathrm{ft}^{2}-\mathrm{h} \cdot{ }^{\circ} \mathrm{F}$.

Subtask 6.1.2 (Chemical Properties of Processed Shales) was initiated during the quarter. Equipment needed for preparing agglomerated and slagged spent shale samples for leaching tests were prepared and checked for operability. The tests will begin when the physical properties tests have been completed on the existing samples.

\section{Subtask 6.2 Water Availability and Treatment Studies}

The objective of this subtask is to determine suitable techniques for treating wastewater generated during shale processing. Tennessee Technology University (TTU) is conducting the work on this subtask.

\section{Subtask 6.2.1 .. Water Treatability}

TTU conducted both batch and continuous studies this quarter to determine the biological treatability of selected compounds. Batch studies were continued to show the chemical/physical removal by activated carbon. The major results which were obtained from these studies are described below.

Biological Treatment - Double substrate batch experiments involving thiocyanate ( $\left.\mathrm{SCN}^{-}\right)$were completed. Figures 6-1 to 6-4 illustrate the batch removal of $\mathrm{SCN}^{-}$in combination with propionitrile and pyrrole, respectively. Minimum chemical oxygen demand (COD) values were reached in 213 hours for the $\mathrm{SCN}^{*} /$ propionitrile experiment and in 243 hours for the SCN /pyrrole experiment. Semi-logarithmic plots of the data show 2 distinct logarithmic phases of substrate removal. In each case, the second $\log$ phase is very similar to the patterns observed in earlier experiments including $\mathrm{SCN}^{\circ}$ alone and in combination with acetone.

Figures $6-5$ and $6-6$ illustrate the biological removal of 4 substrates, acetone, propionitrile, pyrrole, and $\mathrm{SCN}^{-}$, simultaneously. Again, about 240 hours were necessary for minimization of COD, apparently because of the lag phase in the degradation of $\mathrm{SCN}^{-}$.

Preliminary continuous flow studies were conducted during the quarter. One unit was operated with acetone as a single substrate with a concentration of $600 \mathrm{mg} / \mathrm{L}$. The reactor produced an effluent with a COD of about $40 \mathrm{mg} / \mathrm{L}$ at a hydraulic retention time (HRT) of 4 days. A reduction in the HRT to 2 days resulted in an effluent COD of approximately $70 \mathrm{mg} / \mathrm{L}$. Operation of this unit was subsequently discontinued because it had been initiated solely for the purpose of acquainting the TTU staff with the operation and maintenance of a continuous flow reactor. 


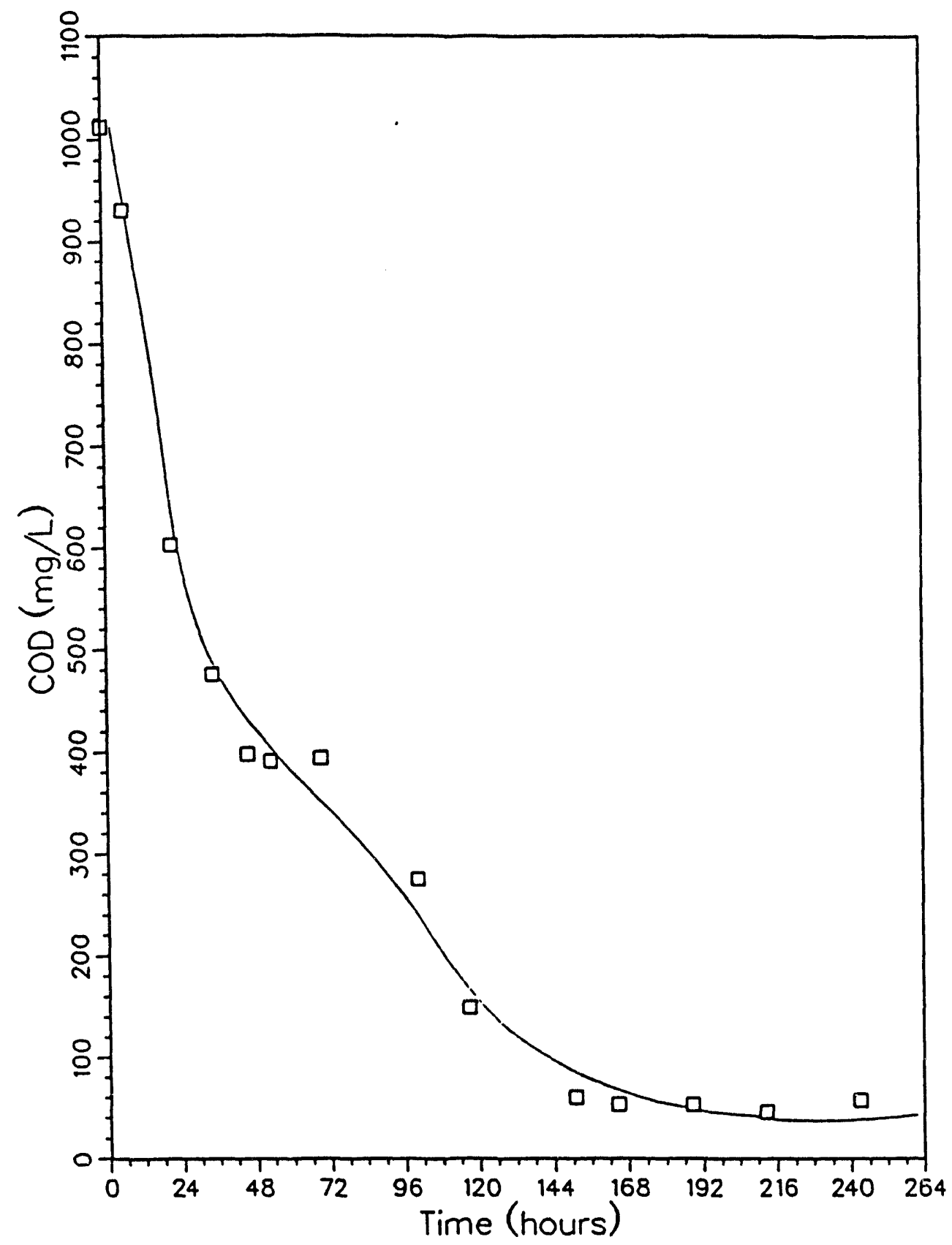

Figure 6-1. BIOLOGICAL REMOVAL OF TWO SUBSTRATES $(300 \mathrm{mg} / \mathrm{L})$ PROPIONITRILE AND SCN $^{-}$INITIALLY) 


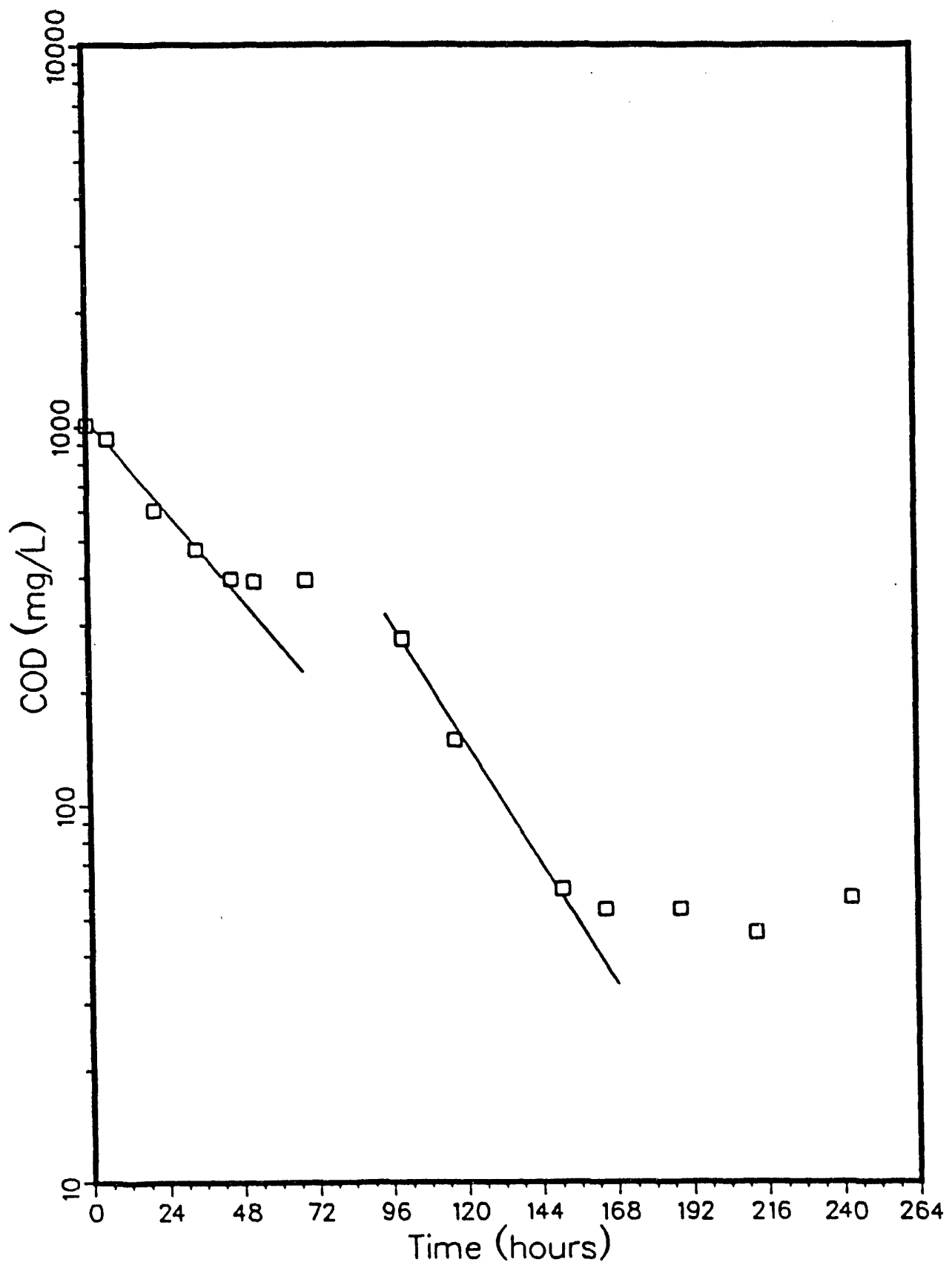

Figure 6-2. BIOLOGICAL REMOVAL OF TWO SUBSTRATES $(300 \mathrm{mg} / \mathrm{L})$ PROPIONITRILE AND SCN ${ }^{-}$INITIALLY): LOG PLOT 


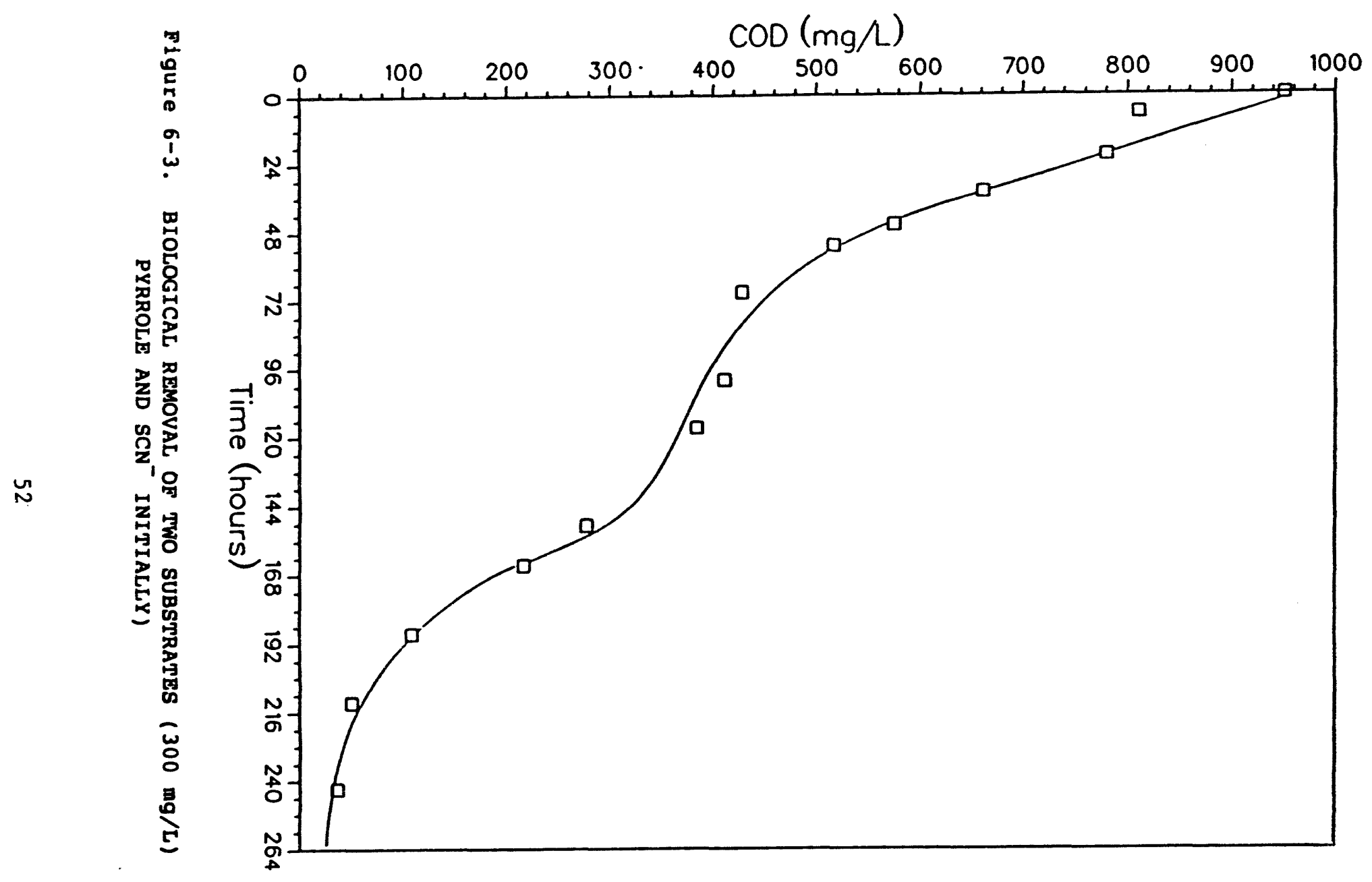




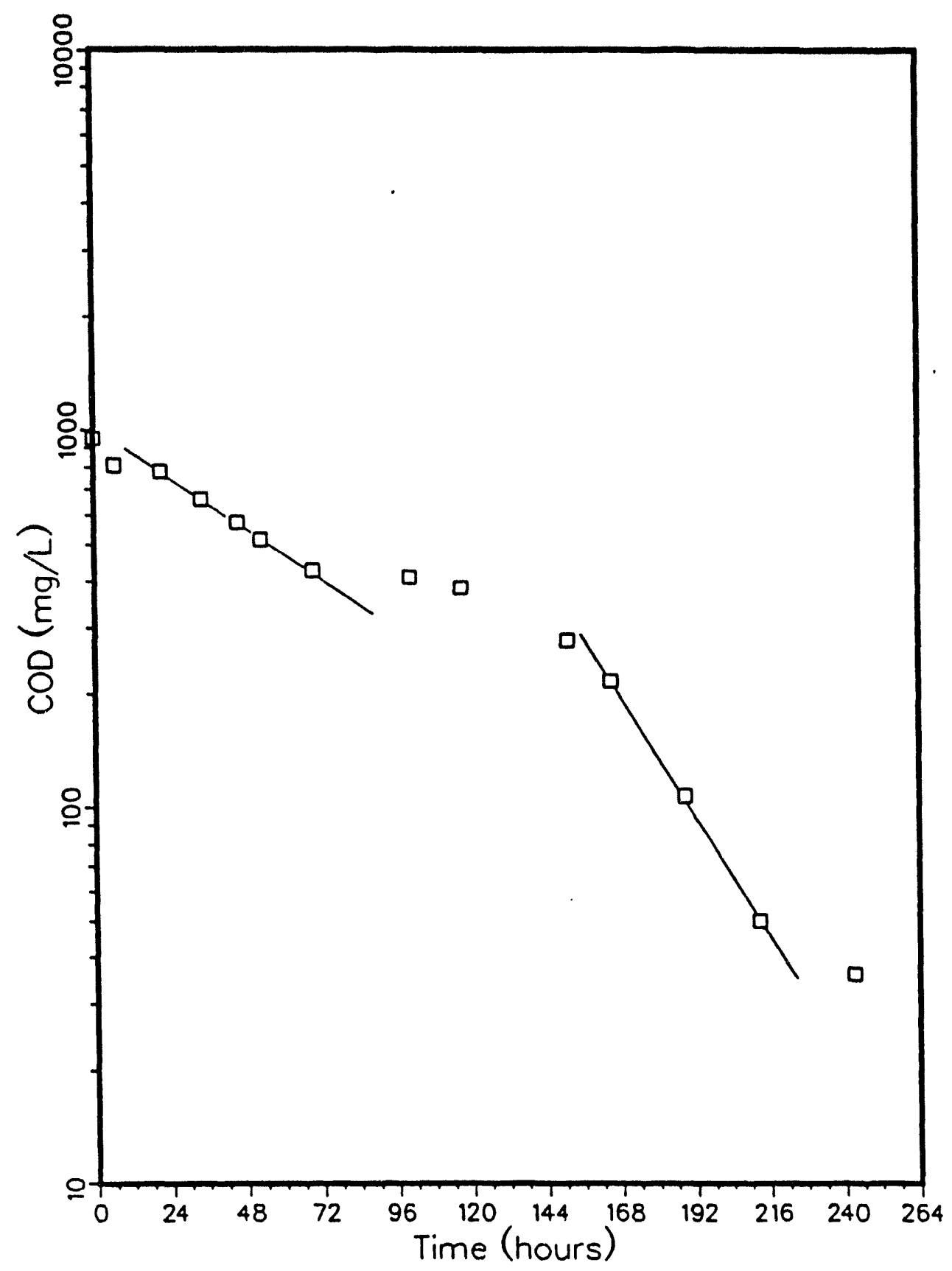

Figure 6-4. BIOLOGICAL REMOVAL OF TWO SUBSTRATES ( $300 \mathrm{mg} / \mathrm{L}$ ) PYRROLE AND SON ${ }^{-}$INITIALLY): LOG PLOT

53 


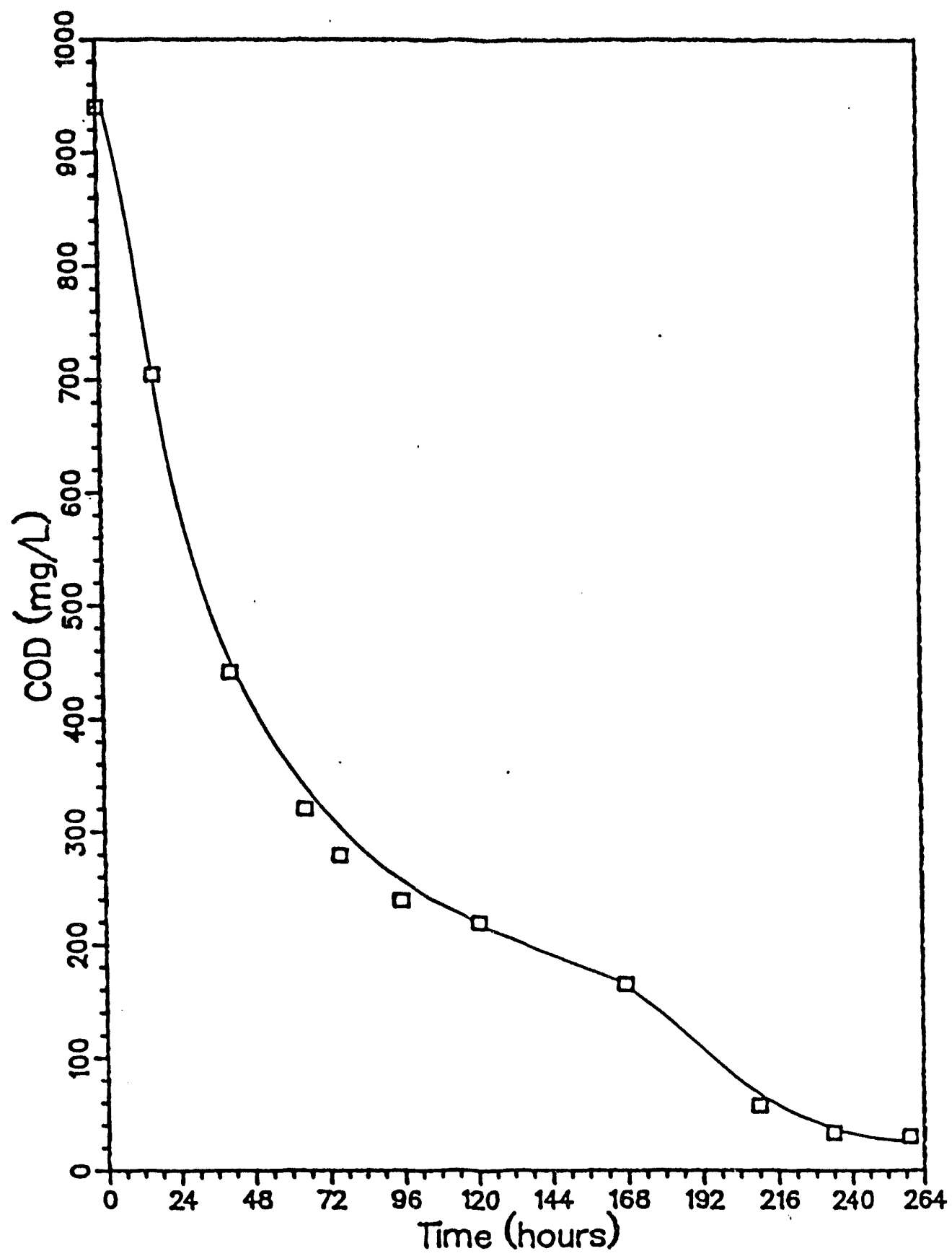

Figure 6-5. BIOLOGICAL REMOVAL OF FOUR SUBSTRATES $(150 \mathrm{mg} / \mathrm{L}$ EACH OF ACETONE, PROPIONITRILE, PYRROLE AND SON ${ }^{-}$INITIALLY)

54 


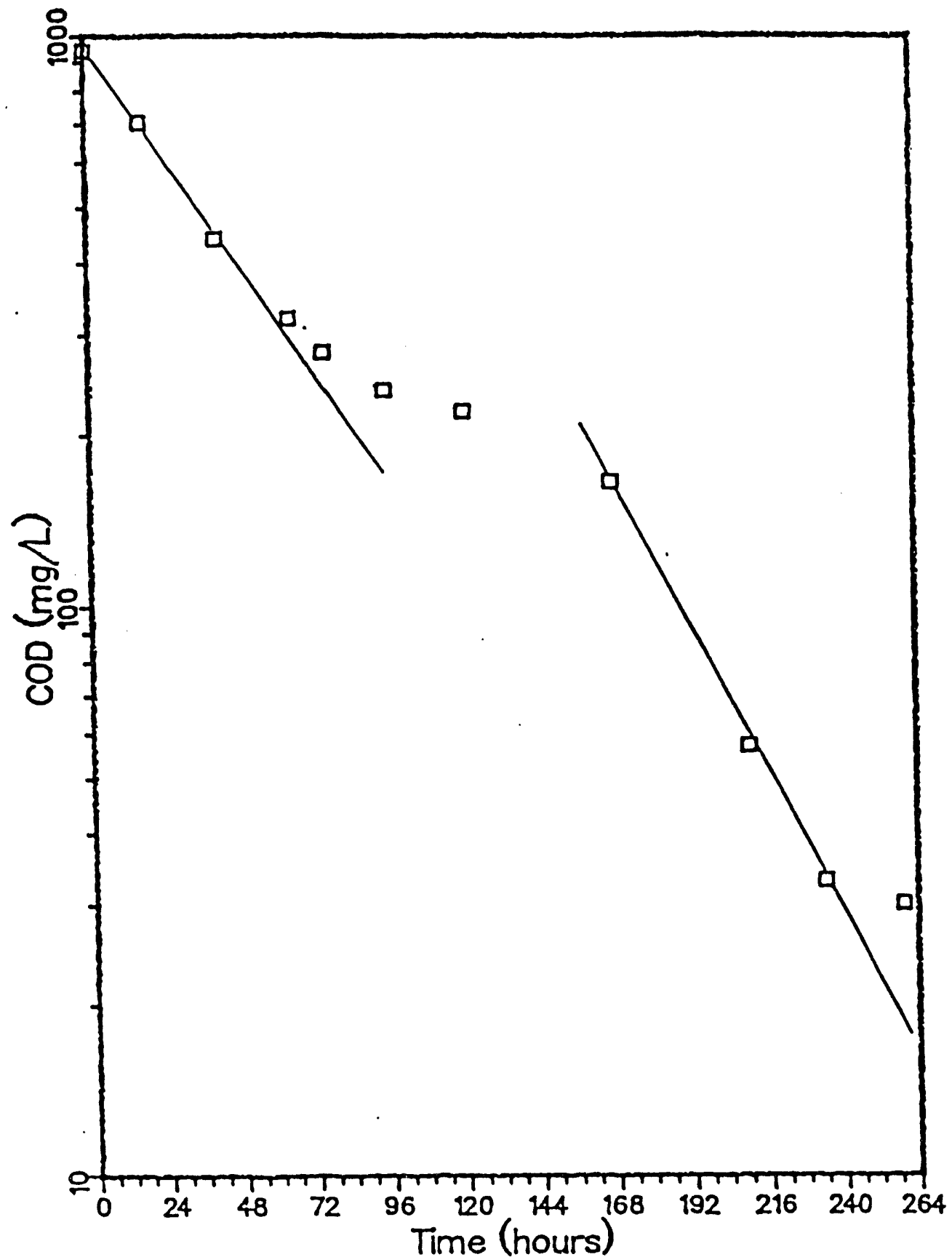

Figure 6-6. BIOLOGICAL REMOVAL OF FOUR SUBSTRATES $(150 \mathrm{mg} / \mathrm{L}$ EACH OF ACETONE, PROPIONITRILE, PYRROLE AND SCN ${ }^{-}$INITIALLY): LOG PLOT 
A second continuous flow activated sludge unit was started and acclimated to a feed solution containing $150 \mathrm{mg} / \mathrm{L}$ of each substrate (acetone, propionitrile, pyrrole, and $\mathrm{SCN}^{-}$). The unit was initially operated using a HRT of 5 days. Samples were taken daily over a period of 2 HRTs. COD and specific substrate analyses were performed on the influent and effluent to determine whether steady state operation was achieved. The concentrations of acetone, propionitrile, and pyrrole ware determined using a Hewlett-Packard $5890 \mathrm{~A}$ gas chromatograph equipped with a flame ionization detector. The colorimetric procedure for cyanides amenable to chlorination was used to analyze samples for $\mathrm{SCN}^{-}$. The results of the analyses (Figure 6-7) show that effluent COD values averaged $90 \mathrm{mg} / \mathrm{L}$, while each of the substrates was reduced to below the detectable limit of $1 \mathrm{mg} / \mathrm{L}$.

Because of the rapid removal of $\mathrm{SCN}^{-}$from the continuous flow reactor, a second batch experiment was performed to show the removal of 4 substrates using microbial seed from the continuous flow unit. As shown in Figures 6-8 and 6-9, the lag phase of $\mathrm{SCN}^{-}$was reduced from about 240 hours to 94 hours, indicating that the continuous flow reactor facilitated better acclimation of microorganisms to $\mathrm{SCN}^{-}$.

Batch biological reactors were initiated to determine the feasibility of degrading $\mathrm{SCN}^{-}$in concentrations exceeding $1000 \mathrm{mg} / \mathrm{L}$. Microbial seed from the continuous flow unit are currently being acclimated to $\mathrm{SCN}^{-}$concentrations ranging from approximately 1000 to $2000 \mathrm{mg} / \mathrm{L}$. Once acclimation has been achieved, degradation experiments will be initiated.

Physical-Chemical Treatment - A study was initiated to determine the removal of the 4 compounds continuously flowing through columns packed with activated carbon. Two columns, each 6 feet 4 inches high and 4 inches in diameter, were filled to a depth of 6 feet with $12 \times 40$ mesh Filtrasorb 300 (Calgon Corporation) activated carbon. The columns were operated in series with a flow rate of 1 gallon/minute $/ \mathrm{ft}^{2}$ of column cross sectional area.

The column was flushed to remove fines and the desired flow rate was established using distilled water. The feed solution containing about 150 $\mathrm{mg} / \mathrm{L}$ of each compound was applied to the wetted column in the same manner as the distilled water. Samples were collected at 5 points (influent, midpoint of column 1, bottom of column 1, midpoint of column 2, and bottom of column 2) at 5-minute intervals. Analyses for each of the 4 compounds were performed on all samples. The data obtained for acetone and propionitrile are shown in Figures $6-10$ and 6-11, respectively. Analysis of the data has not yet been completed.

Based on the batch carbon adsorption studies performed to date, and the results from the column study just shown, carbon adsorption may not be an economically feasible means of primary treatment for the 4 contaminants under consideration. Adsorption of the contaminants by activated carbon may, however, prove to be an acceptable tertiary treatment process to follow a biological reactor. The effectiveness of carbon adsorption at low-level concentrations of the contaminants must be investigated for synthetic waste components and for effluent from a continuous flow biological reactor. The work conducted this quarter included experiments to determine the effectiveness of 


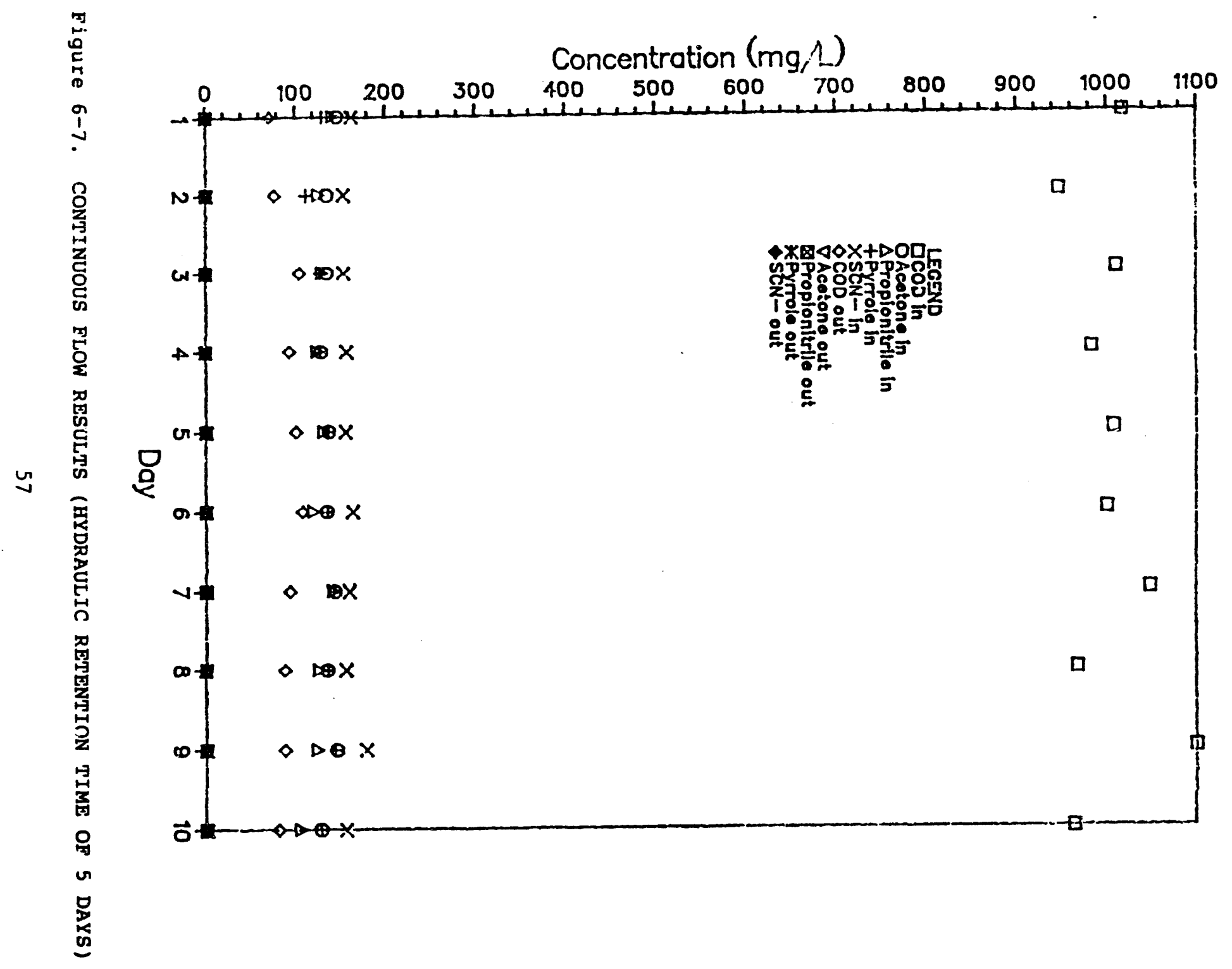




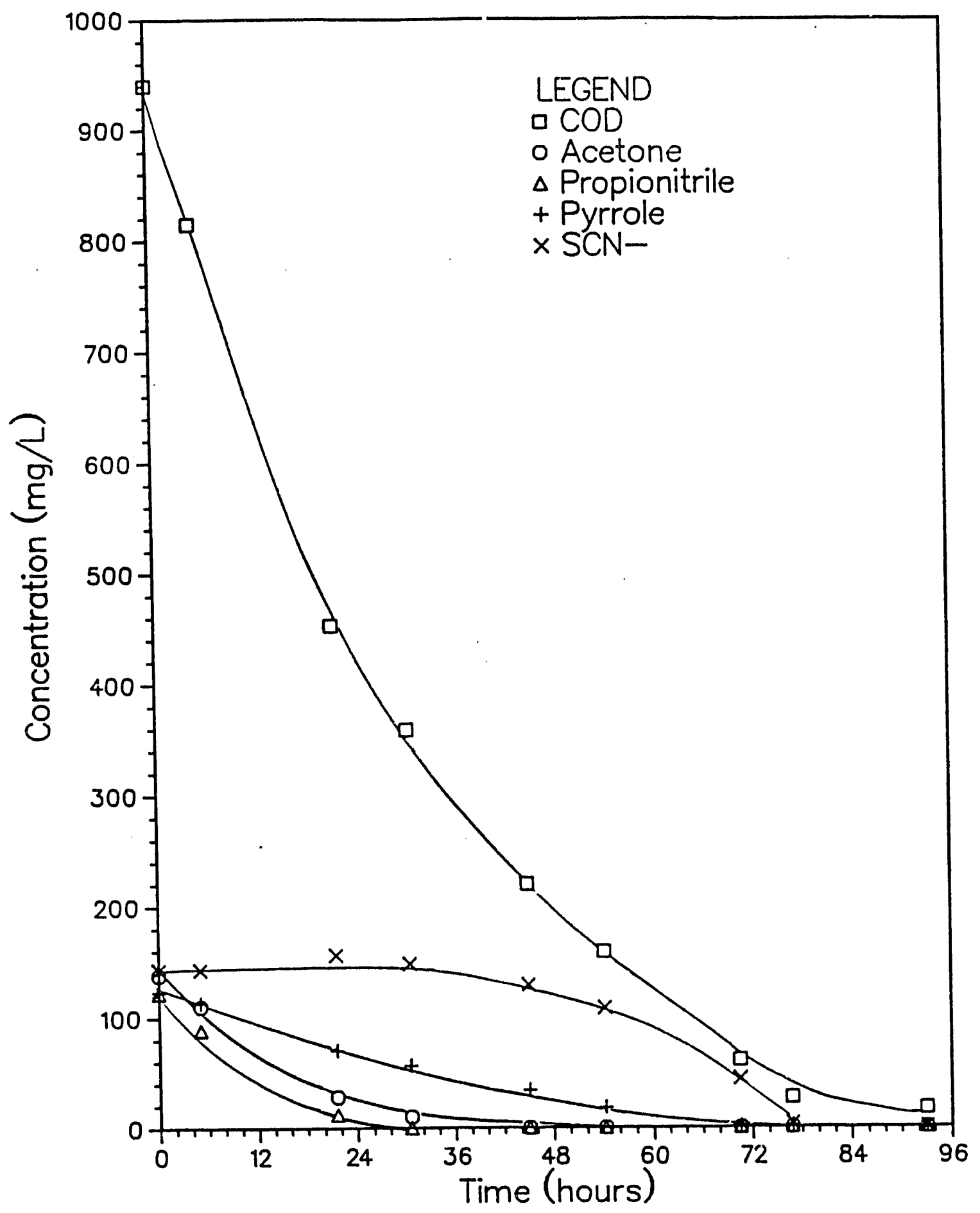

Figure 6-8. REMOVAL OF FOUR SUBSTRATES BY BIOLOGICAL TREATMENT 


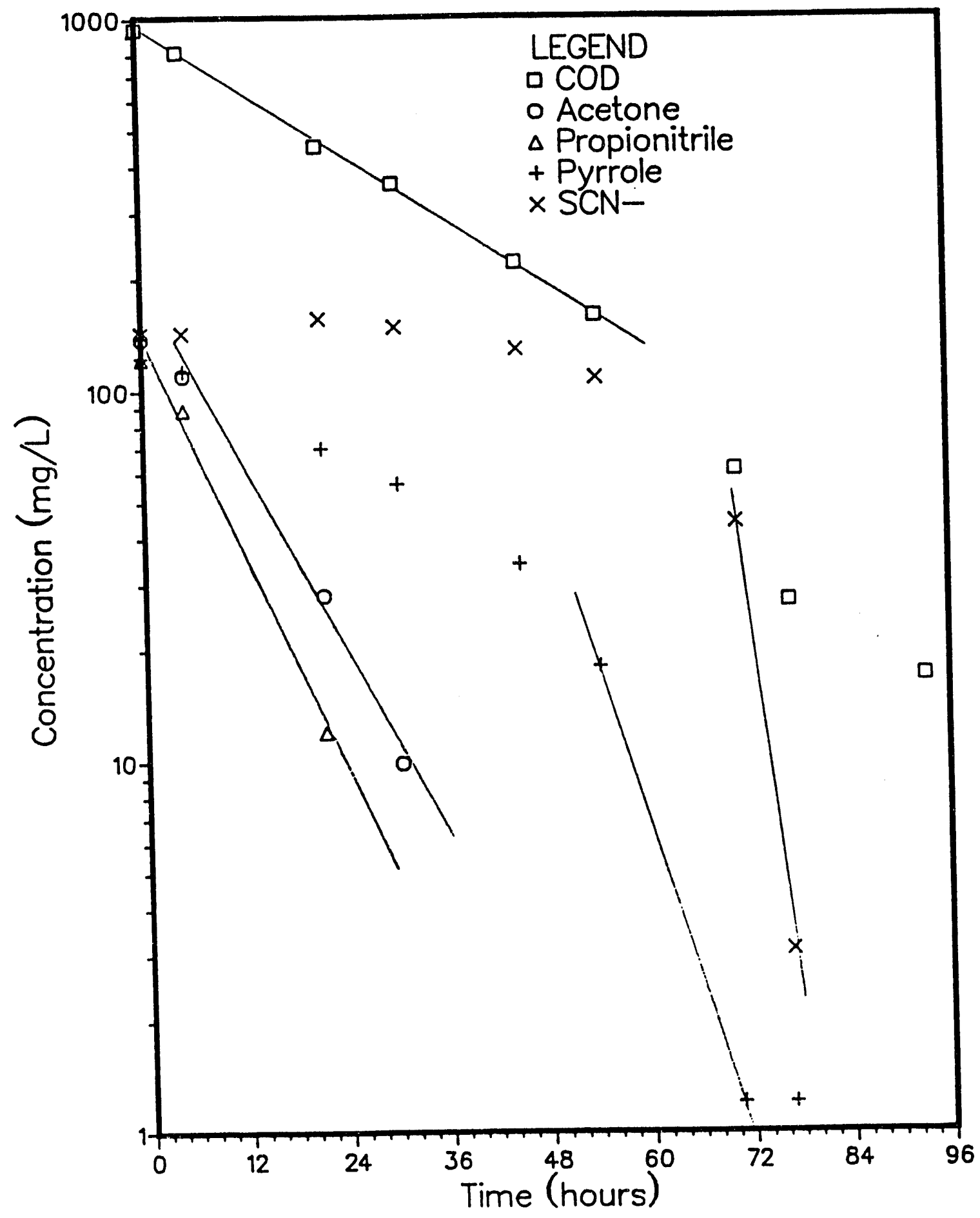

Figure 6-9. REMOVAL OF FOUR SUBSTRATES BY BIOLOGICAL TREATMENT: LOG PLOT 


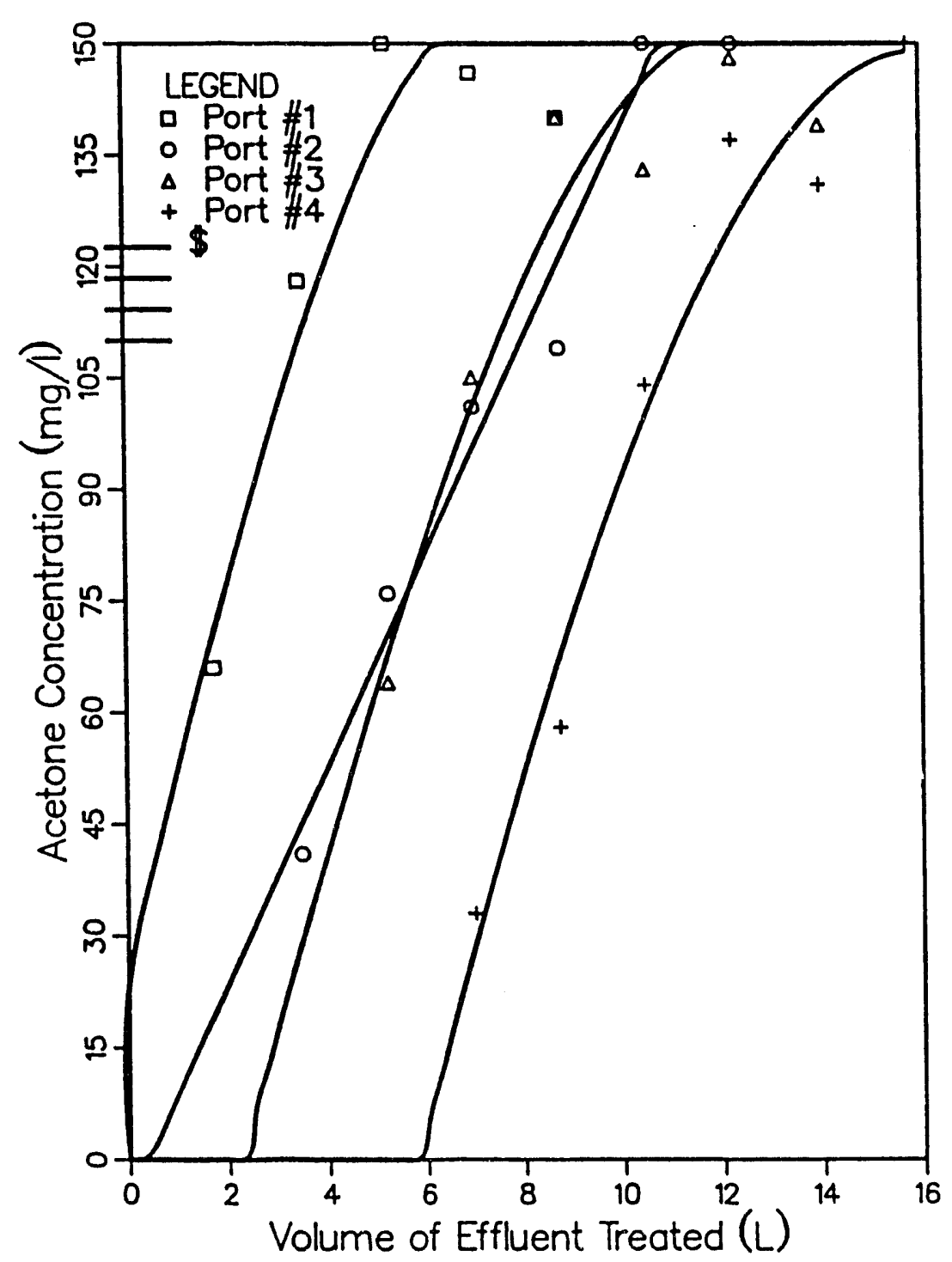

Figure 6-10. EXHAUSTION CURVE FOR THE ABSORPTION OF ACETONE FROM AQUEOUS MULTISOLUTE SOLUTION ONTO F-300 ACTIVATED CARBON 


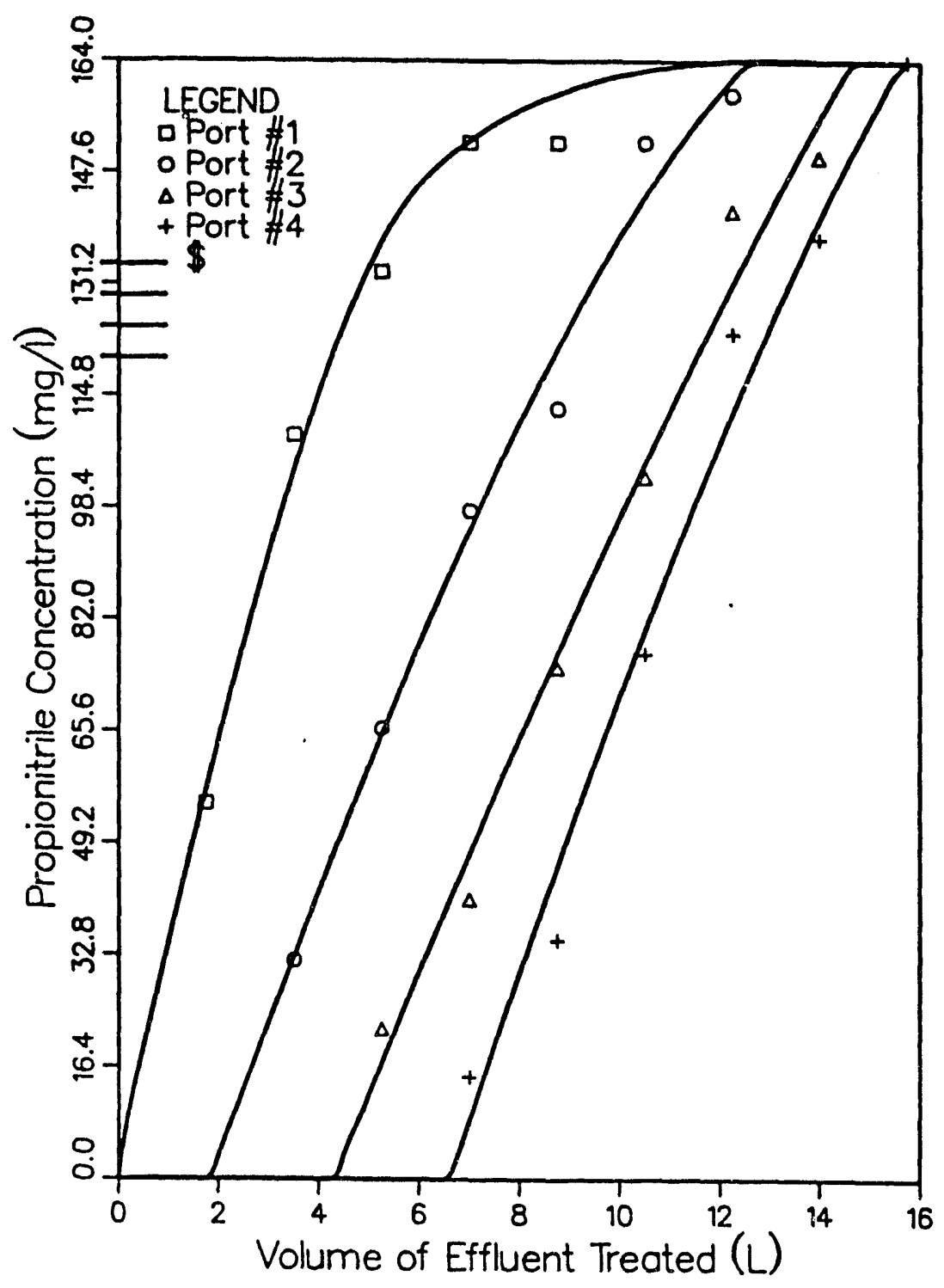

Figure 6-11. EXHAUSTION CURVE FOR THE ADSORPTION OF PROPIONITRILE FROM AQUEOUS MULTISOLUTE SOLUTION ONTO F-300 ACTIVATED CARBON 
activated carbon in adsorbing each of the 4 contaminants from a synthetic waste solution containing concentrations of 5 to $100 \mathrm{mg} / \mathrm{L}$.

Batch carbon adsorption studies were conducted to determine the adsorption of each of the 4 compounds by powdered activated carbon from solutions of relatively low concentrations. The results are presented in Table $6-1$ and in Figures 6-12 through 6-15. For solutions having $\mathrm{SCN}^{-}$concentrations ranging from 5 to $102 \mathrm{mg} / \mathrm{L}$, adsorption was between 2 and $6 \mathrm{mg} / \mathrm{gram}$ of activated carbon. These results compare favorably with the 6 to $15 \mathrm{mg} / \mathrm{gram}$ reported earlier for solutions having concentrations from 70 to $750 \mathrm{mg} / \mathrm{L}$ of $\mathrm{SCN}^{-}$. For solutions having acetone concentrations between 5 and $91 \mathrm{mg} / \mathrm{L}$, removal by adsorption was between 1 and $13 \mathrm{mg} / \mathrm{gram}$ of carbon. These values also compare favorably with removals of 2 to $40 \mathrm{mg} / \mathrm{gram}$ of carbon for higher concentration ranges. For concentrations containing pyrrole between 5 and $88 \mathrm{mg} / \mathrm{L}$, removal by adsorption was between 3 and $33 \mathrm{mg} / \mathrm{gram}$ of carbon. These results coincide quite well with the removal of 40 to $150 \mathrm{mg} / \mathrm{gram}$ of carbon for higher concentration ranges. For solutions with propionitrile concentrations between 4 and $95 \mathrm{mg} / \mathrm{L}$, removal by carbon adsorption was between 0.5 and $14 \mathrm{mg} / \mathrm{gram}$ of carbon. At higher concentration ranges, removals of 10 to $250 \mathrm{mg}$ of propionitrile were obtained. Again, consistent results are shown between low and high concentrations.

For each of these batch carbon adsorption experiments, a contact time of 4 hours was allowed to insure that equilibrium was reached. Figures 6-16 to 6-19 demonstrate that this time period was more than sufficient for attainment of adsorption equilibrium for each compound.

\section{Subtask 6,3. Heavy Metals Removal}

The objective of this subtask is to develop a unified description of the kinetics and mechanisms of the catalyzed and uncatalyzed dissolution of a number of heavy metals and other important minerals from samples of eastern shale. The work on this subtask is being conducted by the University of Michigan (UM).

During the quarter, UM studied the dissolution of barium from shale in hydrochloric $(\mathrm{HCl})$ and nitric $\left(\mathrm{HNO}_{3}\right)$ acids. Also, studies of $\mathrm{Ba}$ dissolution from retorted shale in $\mathrm{HCl}$ catalyzed with sodium chloride (NaCl) were initiated. The results of a test conducted with $0.1 \mathrm{M} \mathrm{NaCl}$ in $1 \mathrm{M} \mathrm{HCl}$ showed a reduction in the dissolution rate by about 508 compared to that with uncatalyzed $\mathrm{HCl}$. However, in another test conducted with $0.1 \mathrm{M} \mathrm{NaCl}$ in $0.1 \mathrm{M} \mathrm{HCl}$, the reaction rate was enhanced by 7.6 times compared to the uncatalyzed case (Figure $6-20)$. In tests using a brine solution $(0.01$ and $0.1 \mathrm{M} \mathrm{NaCl})$, the $\mathrm{Ba}$ dissolution rate was about $1 / 3$ that of the uncatalyzed case (Figure 6-21). Accordingly, UM revised the rate law for $\mathrm{Ba}$ dissolution from retorted shale in $\mathrm{HCl}$ :

$$
r_{B a} "=1.6 \times 10^{-9}[\mathrm{HCl}]^{0.6}
$$

Additional experiments will be conducted next quarter using $0.1 \mathrm{M} \mathrm{HCl}$ and $0.5 \mathrm{M}$ $\mathrm{NaCl}$. 
Table 6-1. ADSORPTION OF SCN ${ }^{\circ}$, ACETONE, PYRROLE, AND PROPIONITRILE BY FILTRASORB 300 POWDERED ACTIVATED CARBON

\begin{tabular}{|c|c|c|c|c|}
\hline \multicolumn{2}{|c|}{$\mathrm{SCN}^{-}$} & \multirow[b]{2}{*}{$\mathrm{X}^{*}$ (mg) } & \multirow[b]{2}{*}{$M^{* \star}(g)$} & \multirow[b]{2}{*}{$(\mathrm{X} / \mathrm{M})$} \\
\hline $\begin{array}{l}\text { Initial } \\
\text { Conc. }\end{array}$ & $\begin{array}{l}\text { Final } \\
\text { Conc. }\end{array}$ & & & \\
\hline$\ldots \ldots$ & $\ldots \ldots$ & & & \\
\hline 4.63 & 2.. 77 & 2.86 & 1.25 & 2.29 \\
\hline 9.42 & 5.42 & 4.00 & 1.25 & 3.20 \\
\hline 31.29 & 26.30 & 4.99 & 1.25 & 3.99 \\
\hline 50.75 & 44.65 & 6.10 & 1.25 & 4.88 \\
\hline 76.00 & 69.10 & 6.90 & 1.25 & 5.52 \\
\hline 101.89 & 93.91 & 7.98 & 1.25 & 6.38 \\
\hline
\end{tabular}

\begin{tabular}{|c|c|c|c|c|}
\hline \multicolumn{2}{|c|}{ ACETONE } & & & \\
\hline Initial & Final & & & \\
\hline Conc. & Conc, & & & \\
\hline 4.78 & 3.41 & 1.37 & 1.25 & 1.10 \\
\hline 8.90 & 6.68 & 2.22 & 1.25 & 1.78 \\
\hline 26.23 & 20.53 & 5.70 & 1.25 & 4.56 \\
\hline 45.43 & 39.96 & 9.47 & 1.25 & 7.58 \\
\hline 72.47 & 58.72 & 13.75 & 1.25 & 11.00 \\
\hline 91.03 & 74.81 & 16.22 & 1.25 & 12.98 \\
\hline
\end{tabular}

\begin{tabular}{|c|c|c|c|c|}
\hline \multicolumn{2}{|c|}{ PYRROLE } & & & \\
\hline Initial & Final & & & \\
\hline Conc. & Conc. & & & \\
\hline$\cdots \cdot$ & $\cdots$ & & & \\
\hline 4.80 & 0.87 & 3.93 & $\begin{array}{l}1.25 \\
1.25\end{array}$ & 3.14 \\
\hline $\begin{array}{r}8.29 \\
25.35\end{array}$ & $\begin{array}{l}2.04 \\
9.39\end{array}$ & $\begin{array}{r}6.25 \\
15.96\end{array}$ & $\begin{array}{l}1.25 \\
1.25\end{array}$ & $\begin{array}{r}5.00 \\
12.77\end{array}$ \\
\hline 43.78 & 19.08 & 24.70 & 1.25 & 19.76 \\
\hline 69.26 & 32.77 & 36.49 & 1.25 & 29.19 \\
\hline 88.13 & 46.38 & 41.75 & 1.25 & 33.40 \\
\hline
\end{tabular}

\begin{tabular}{|c|c|c|c|c|}
\hline \multicolumn{2}{|c|}{ PROPIONITRILE } & & & \\
\hline Initial & Final & & & \\
\hline Conc. & Conc. & & & \\
\hline 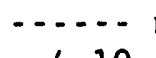 & $\cdots$ & & & \\
\hline 4.10 & 3.48 & 0.62 & 1.25 & 0.50 \\
\hline 8.85 & 7.29 & 1.56 & 1.25 & 1.25 \\
\hline 26.15 & 21.60 & 4.55 & 1.25 & 3.64 \\
\hline 44.50 & 36.28 & 8.22 & 1.25 & 6.58 \\
\hline 78.56 & 63.59 & 14.97 & 1.25 & 11.98 \\
\hline 95.40 & 77.35 & 18.04 & 1.25 & 14.44 \\
\hline
\end{tabular}

* $X=$ (initial concentration minus final concentration), $\mathrm{mg} / \mathrm{L}$.
** $M=$ dosage of carbon, $\mathrm{g} / \mathrm{L}$. 


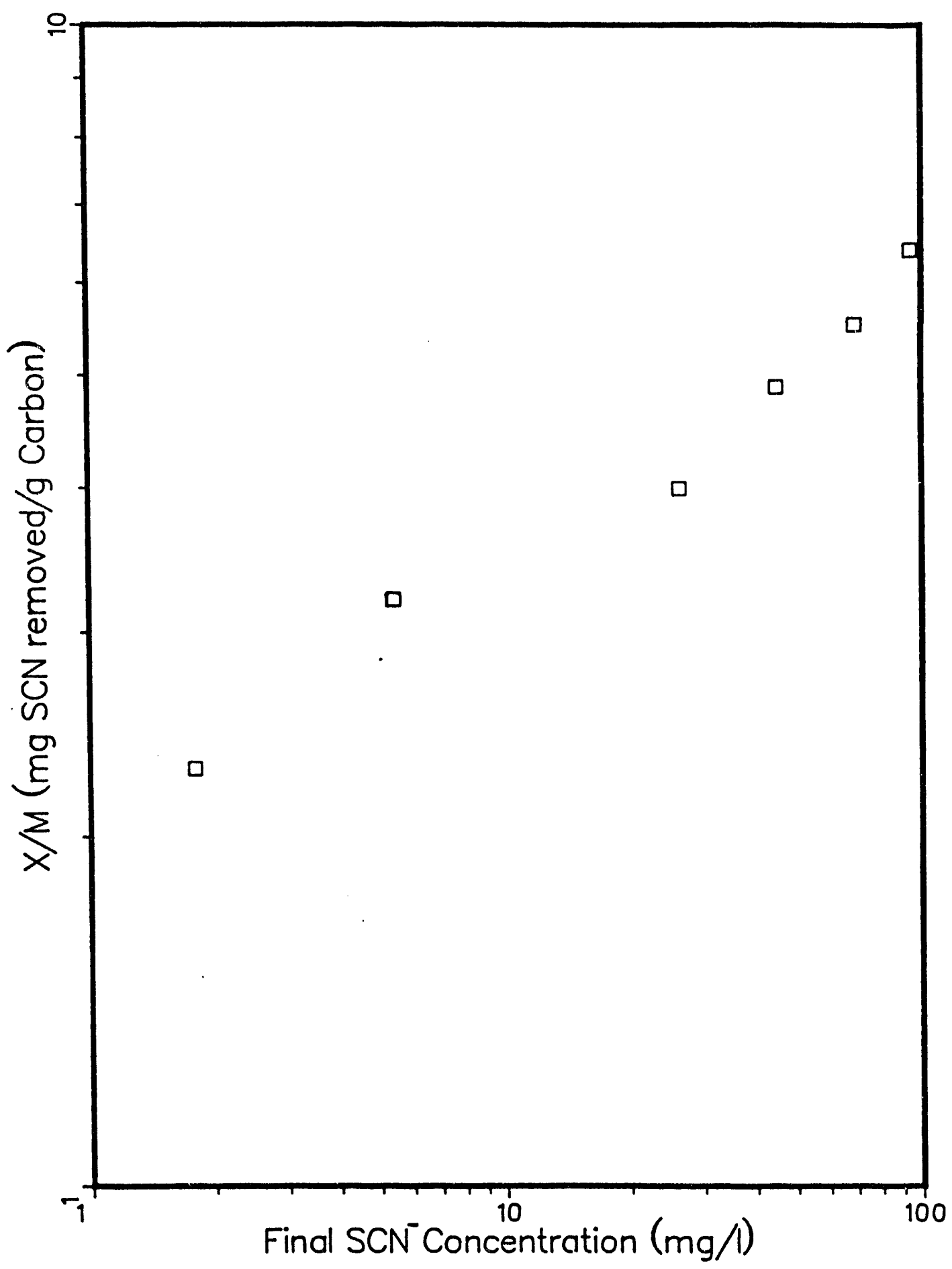

Figure 6-12. THIOCYANATE ADSORPTION: FREUNDLICH ISOTHERM FOR FILTRASORB 300 (THIOCYANATE RANGE: $5-100 \mathrm{mg} / \mathrm{L}$ ) 


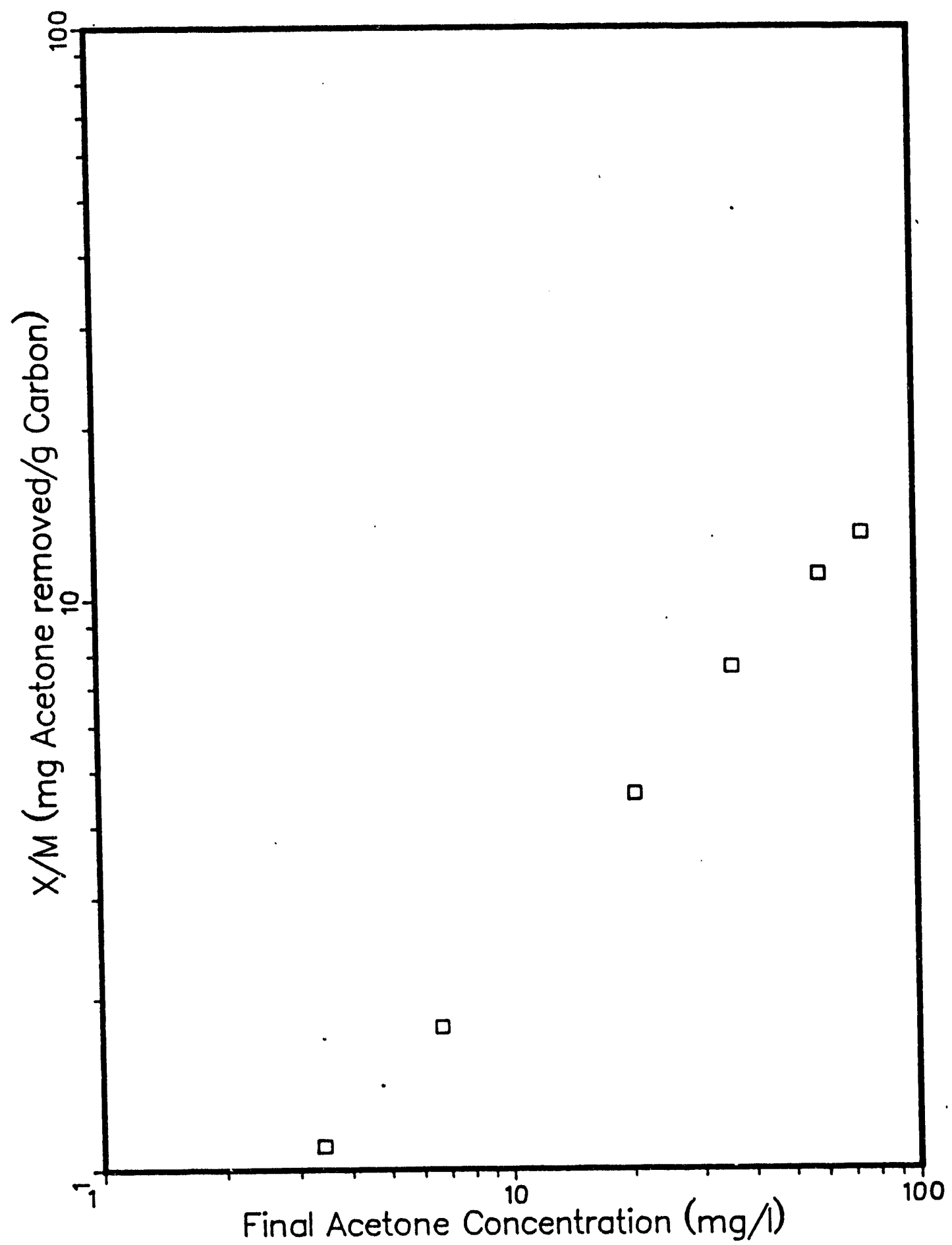

Figure 6-13. ACETONE ADSORPTION: FREUNDLICH ISOTHERM FOR FILTRASORB 300 (ACETONE RANGE: 5-100 mg/L) 


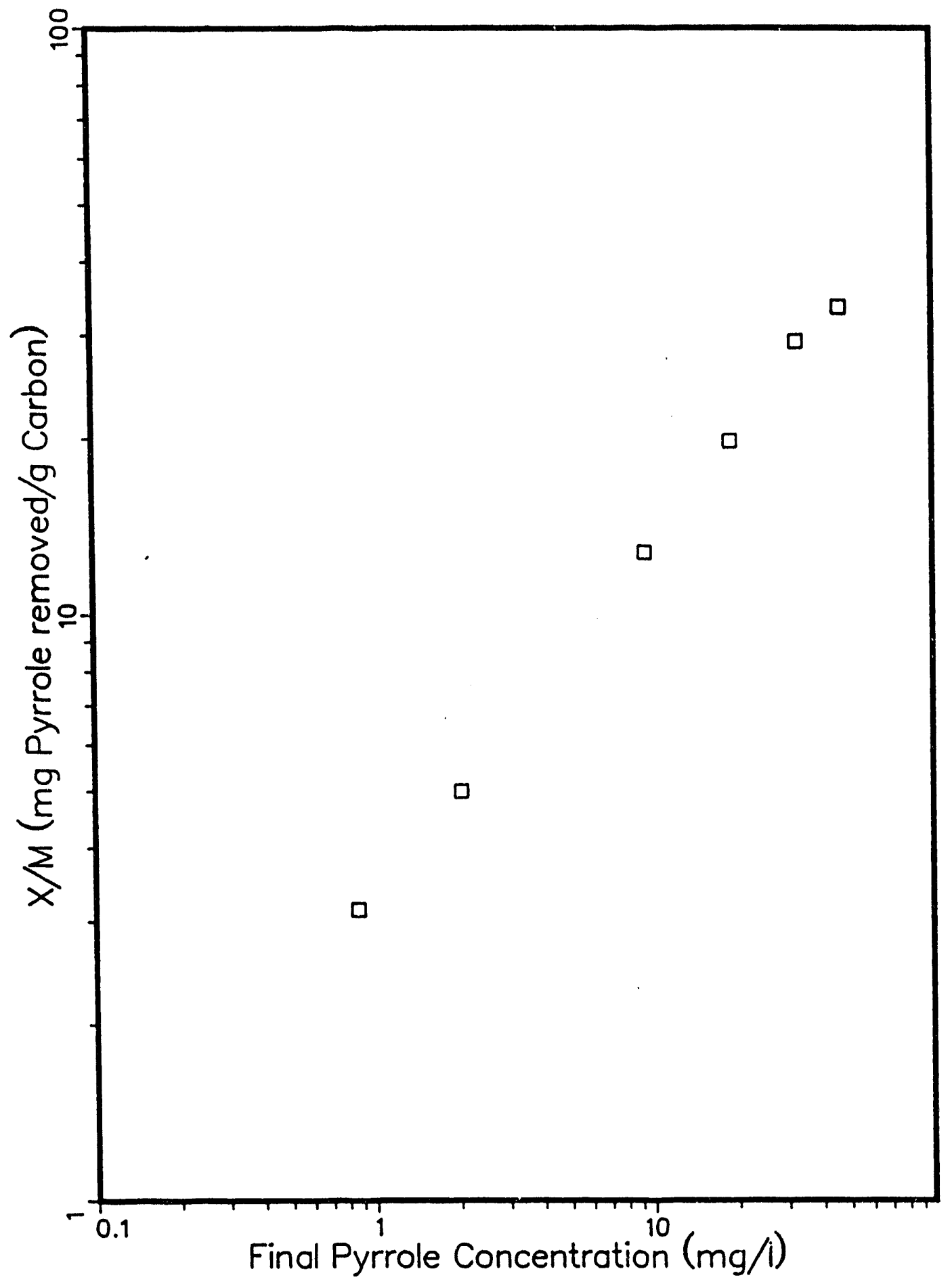

Figure 6-14. PYRROLE ADSORPTION: FREUNDLICH ISOTHERM FOR FILTRASORB 300 (PROPIONITRILE RANGE: 5-100 mg/L) 


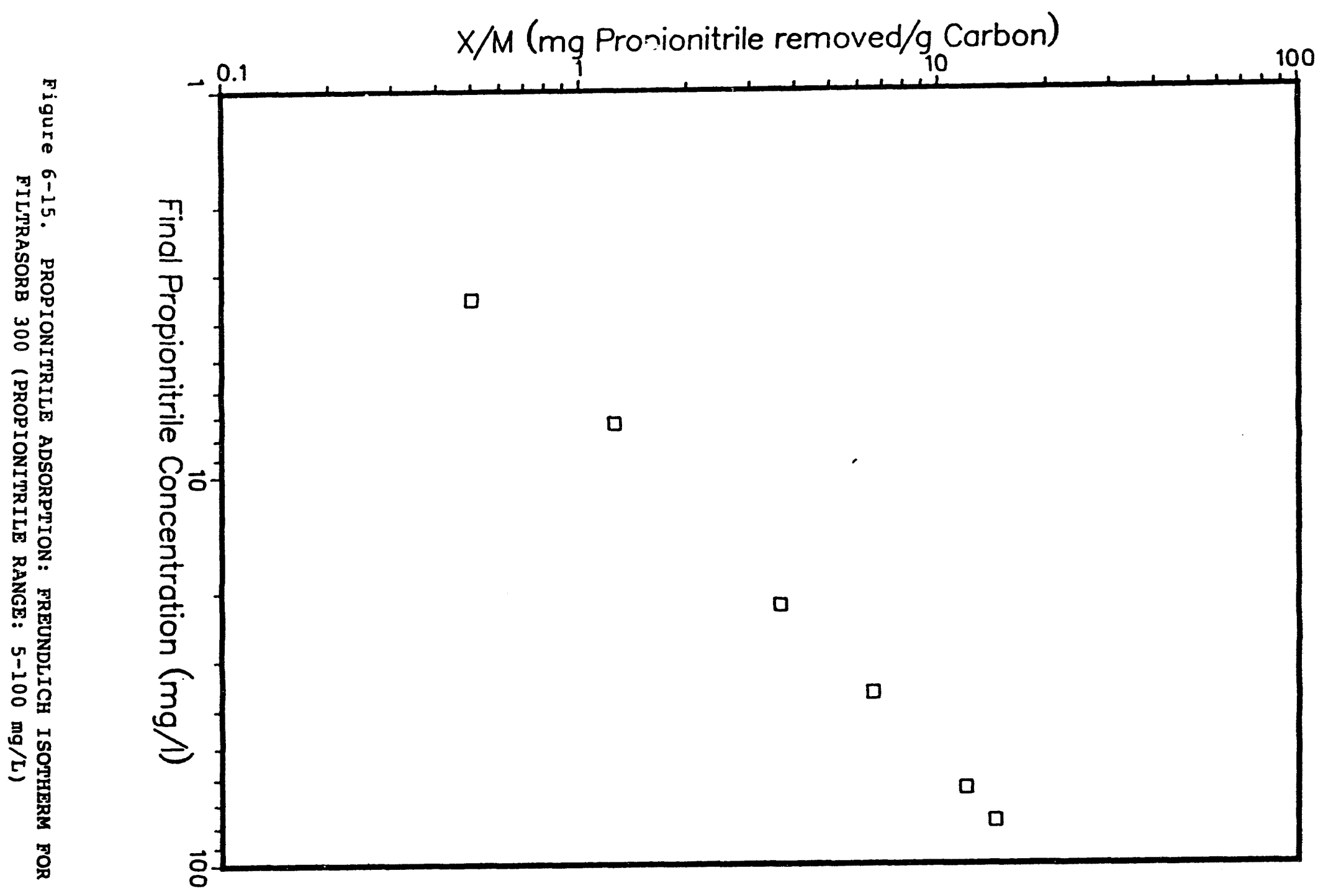


OOE 88OSY4LTIA \&OA

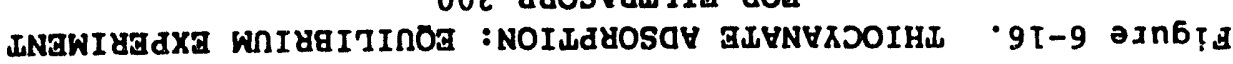

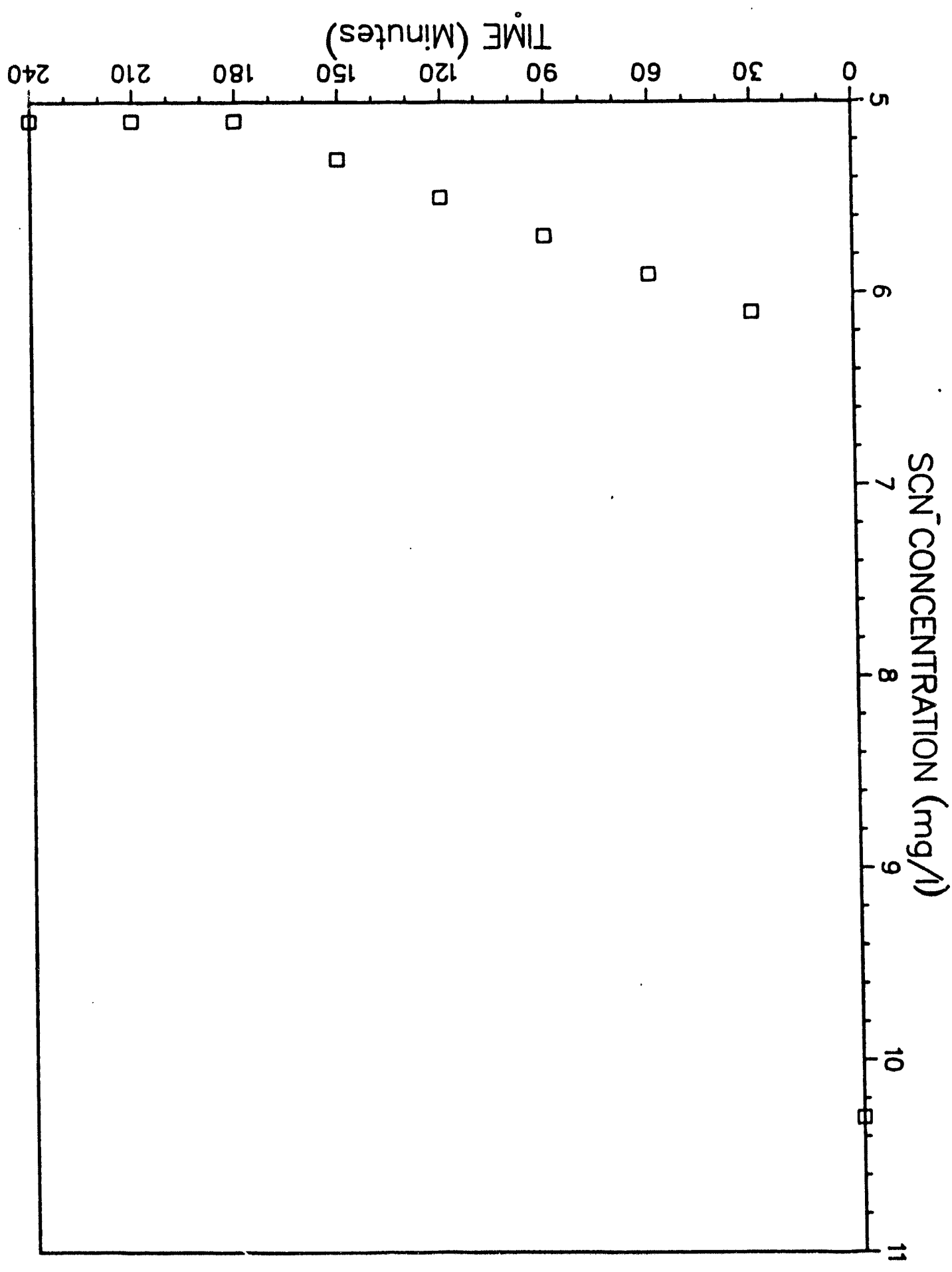




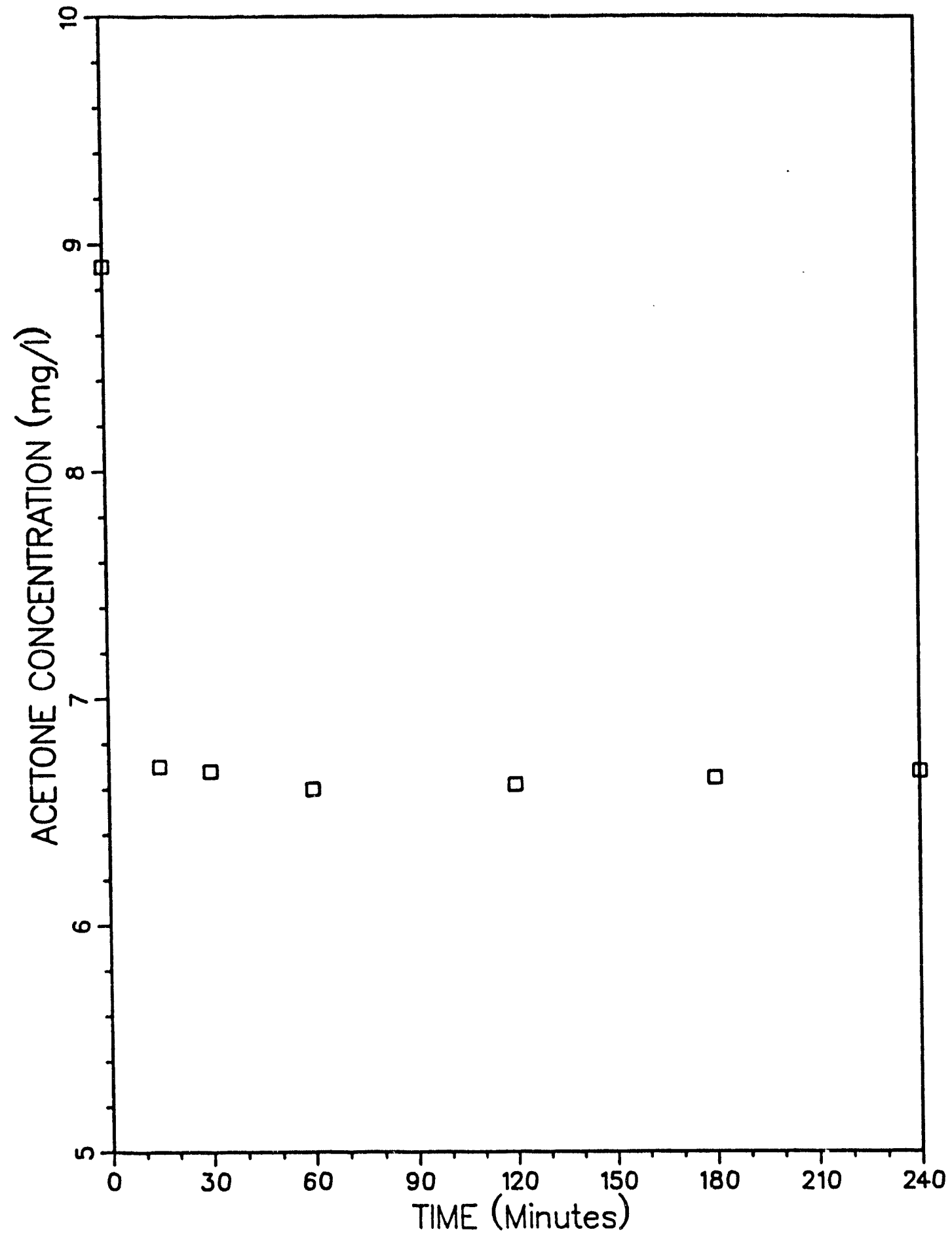

Figure 6-17. ACETONE ADSORPTION: EQUILIBRIUM EXPERIMENT FOR FILTRASORB 300 


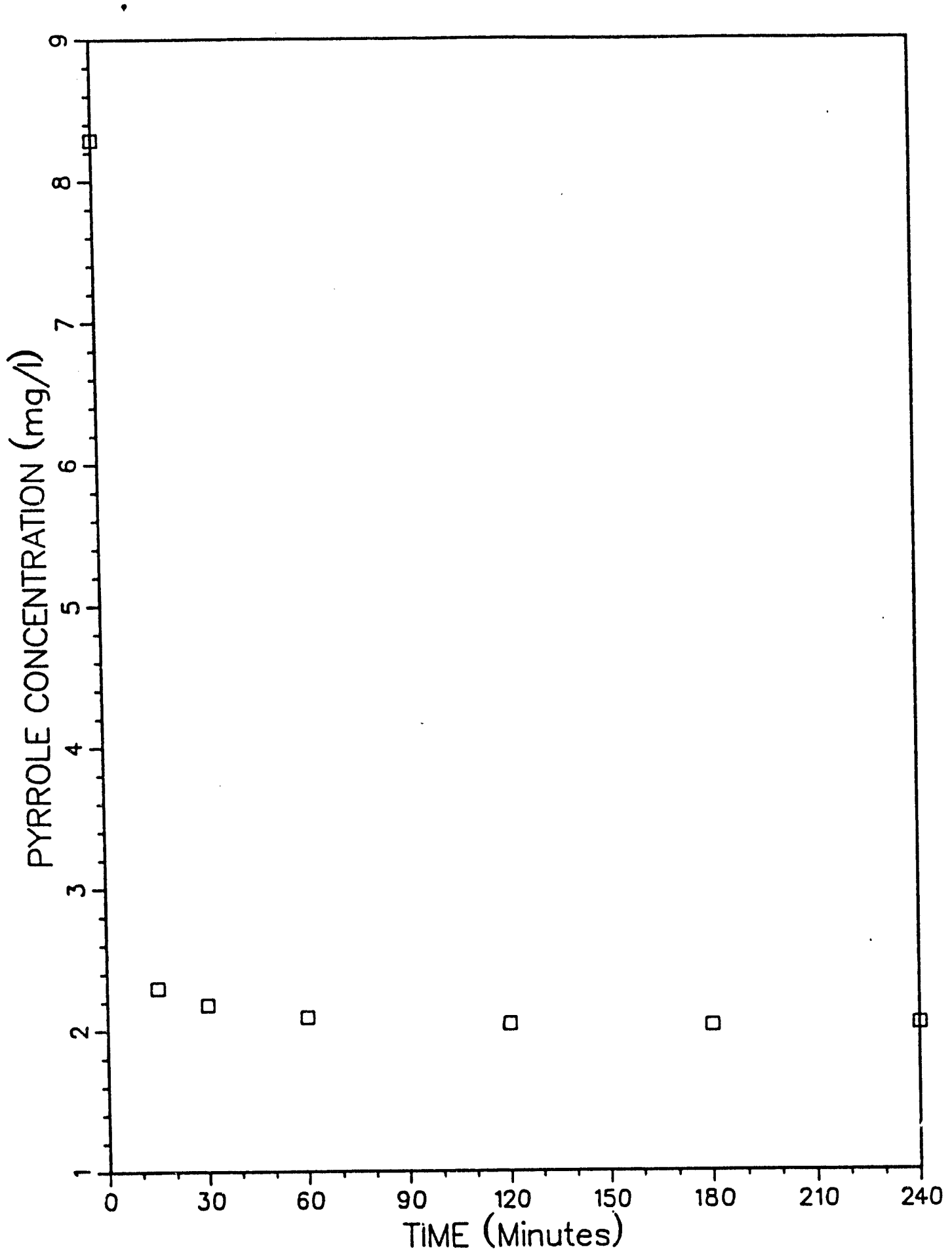

Figure 6-18. PYRROLE ADSORPTION: EQUILIBRIUM EXPERIMENT FOR FILTRASORB 300 


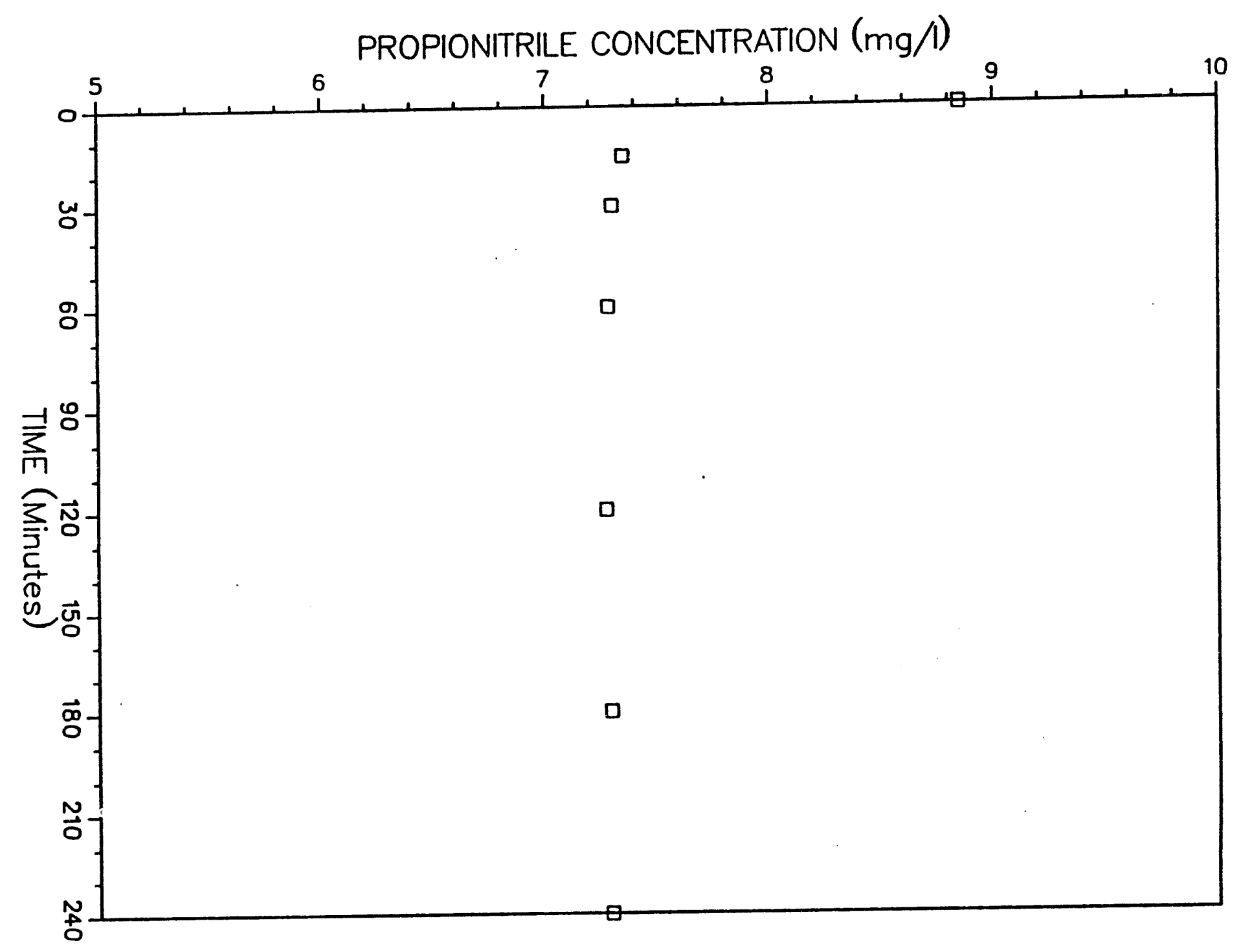




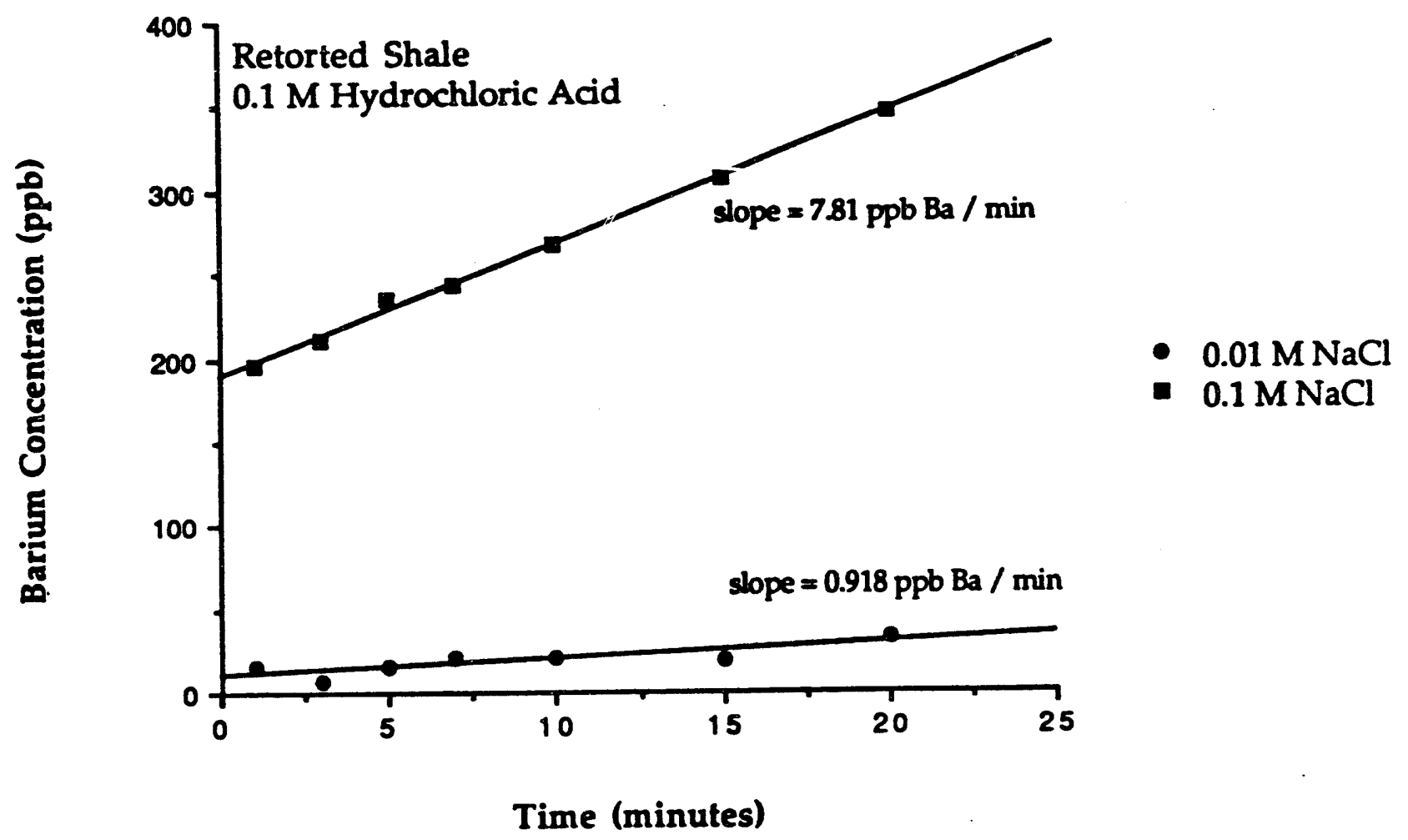

Figure 6-20. BARIUM DISSOLUTION IN $\mathrm{CHI} / \mathrm{NaCl}$ 


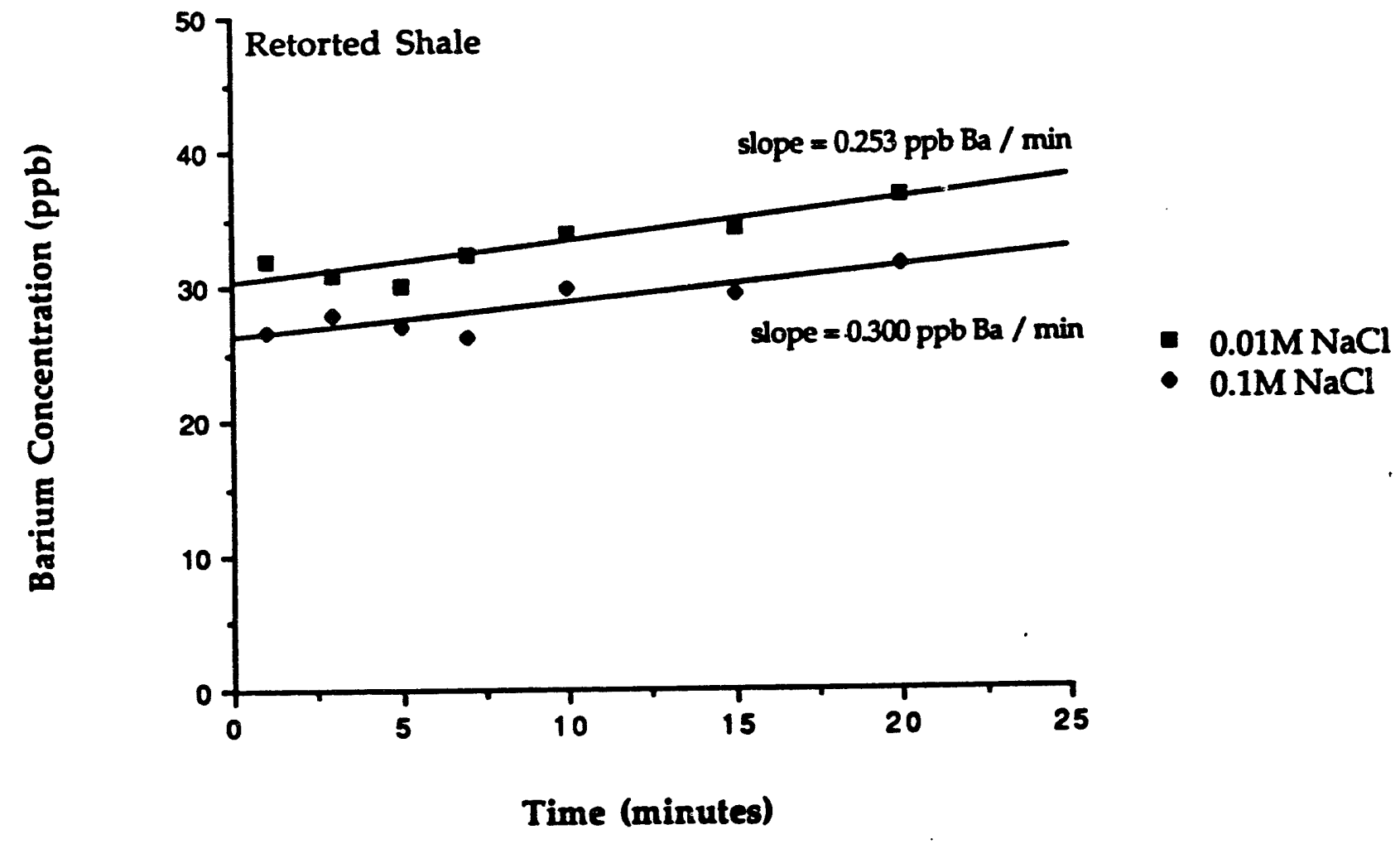

Figure 6-21. BARIUM DISSOLUTION IN BRINE 
UM also conducted tests with sodium hydroxide (NaOH), hydriodic (HI) acid, $\mathrm{HCl}$ and $\mathrm{NaCl}$, and $\mathrm{HNO}_{3}$ to determine the effects on cadmium dissolution from a rotating cadmium sulfide (CdS) disk. The results with $0.1 \mathrm{M} \mathrm{NaOH}$ showed a reaction rate 2 to 3 orders of magnitude lower than those typically observed for halogenic acids. Since $\mathrm{NaOH}$ appears to inhibit the reaction rate, no further investigation of $\mathrm{NaOH}$ will be conducted. Analysis of the data from tests with $0.01,0.1$, and $1.0 \mathrm{M}$ HI (Figure 6-22) yielded the rate law -

$$
r_{c d}{ }^{\prime \prime}=10^{-7} \text { (activity) }^{1.5}
$$

Tests with $1 \mathrm{M} \mathrm{HCl}$ catalyzed with $0.01,0.1$, and $1.0 \mathrm{M} \mathrm{NaCl}$ were also conducted with the rotating CdS disk. The reaction rates of the tests conducted with 0.01 and $0.1 \mathrm{M} \mathrm{NaCl}$ catalyst solutions were lower than that of the uncatalyzed case. The $1.0 \mathrm{M} \mathrm{NaCl}$ solution showed a rate 308 higher than that of the uncatalyzed case.

The tests with $\mathrm{HNO}_{3}$ (Figure 6-23) showed considerable scatter, although the trend is toward higher reaction rate with increasing acid concentration. The slope of the curve through the data points is about 0.3 - substantially less than that observed with halogenic acid. Further tests will be conducted to reduce the uncertainty of the data.

\section{Subtask 6.4.1. PFH System Analyses}

The objective of this subtask is to define the effluent streams, quantities, and compositions for a fluidized-bed hydroretorting plant utilizing various Eastern raw and beneficiated shales.

\section{Discussion}

During the quarter, correlations developed for estimating the oil and gas yields from $\mathrm{PFH}$ processing of Indiana shale were incorporated into the existing computer program that simulates the PFH process. The computer program was tested with the correlations and the material and energy balances were successfully closed. The program can now be used for estimating the compositions and quantities of effluent streams from a PFH plant of desired capacity.

As these correlations are refined, or as new correlations are developed for estimating the oil and gas yields from PFH processing of the other 5 shales in the study, they will be incorporated into the program.

\section{Subtask 6.4.2. Environmental Impact}

The objectives of this subtask are to provide an environmental assessment of a PFH facility and to compare the results with those for a conventional thermal retorting facility. TTU is conducting the work on this subtask. 

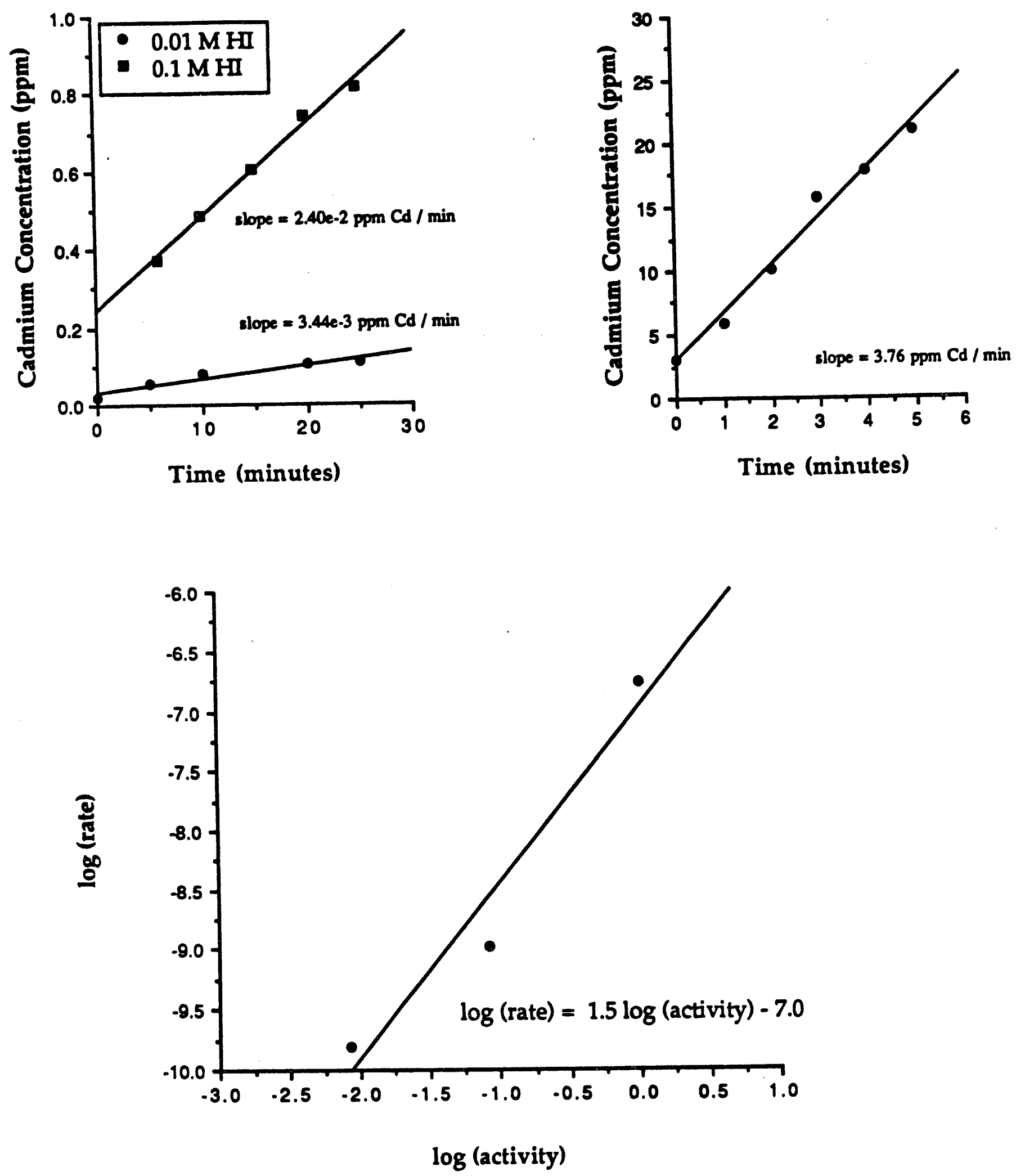

Figure 6-22. CdS DISSOLUTION IN HI (PARTS $a, b$, AND $c$ ) 


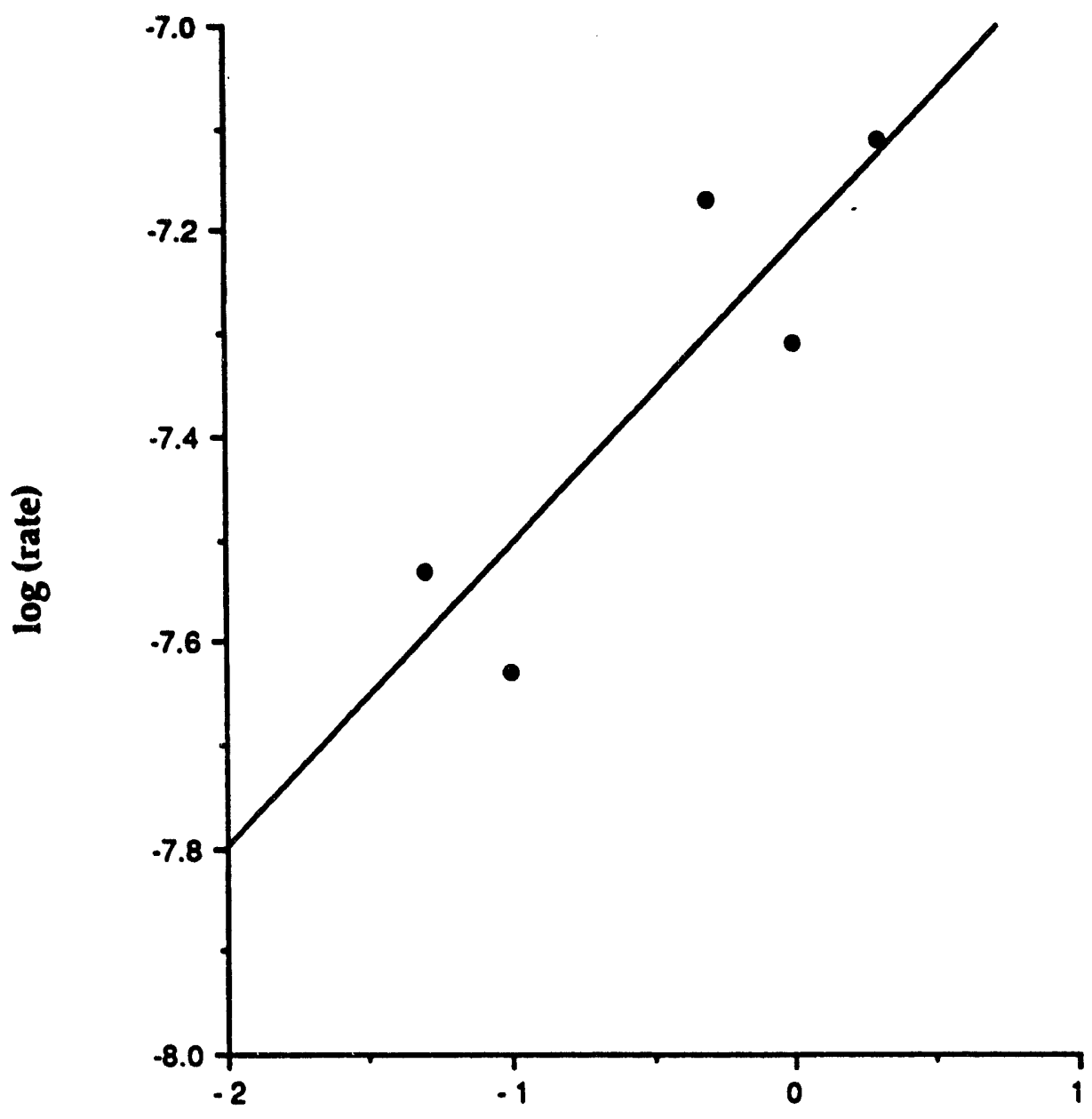

$\log$ [HNO3]

Figure 6-23. Cas DISSOLUTION IN NITRIC ACID 


\section{Discussion}

Progress on this subtask is heavily dependent upon the availability of information from others. Specifically, each segment is dependent upon either the identification of pertinent publications or contact with the appropriate agencies of Federal and state governments. The major accomplishments are presented below.

Impacts - The literature search to collect data on the environmental impacts from the processing of Eastern oil shales by hydro- and thermal retorting was completed this quarter. All publications and articles identified in the search have been received and/or requested. Much of the data reported in these publications is based on shale hydroretorting. Very few data from thermal retorting have been found in the open literature. This complicates the task of comparing thermal-retorting with hydroretorting considerably. The data available for either thermal or hydroretorting are listed below:

1. Spent Shale Production Associated with the Processing of Tennessee Oil Shale. ${ }^{3}$

2. Mobility and Relative Pollutant Ratio of Major and Trace Elements of Tennessee Shale. ${ }^{3}$

3. Representative Values for Chattanooga and Other Eastern Shales. ${ }^{4}$

4. Major and Trace Elements in Product 0il.5

5. Major and Trace Elements in Processed Eastern 0il Shales. 5

6. Analysis of Sour Water from Processed Eastern Oil Shales. 5,9

7. Results of EP Toxicity Test on Processed Tennessee Shale. 4,9

8. Elemental Analysis of Raw Shale 011 from Hydroretorting of Chattanooga Shale. ${ }^{4}$

9. Recovery of Major and Trace Elements from Processed Shale. 5

10. ICP Screen Analyses for Leachate Sample Concentration. ${ }^{6}$

11. Concentrations in ASTM Water Shake and RCRA Tests Extracts -. Hytort Spent Shale.

12. Leachate Mass from Hytort Shale as Indicated by the ASTM Proposed Water Shake Test and RCRA Extraction Test. ${ }^{7}$

13. Potential Pollutants Emanating from Hydroretorting of Eastern Oil Shale. 5

14. Gas Analyses from Recycle Gas Retorting Tests. ${ }^{8}$

15. Effluent Gas Analysis from Tests with No Gas Recycle. ${ }^{8}$

Although these data are available, they were not obtained from the same sample of shale. Thus, direct comparisons will be difficult at best. The following list shows the data needed in order to have the same type of information on both processes.

\section{Thermal-Retorting}

1. Major and Trace Elements in Processed Eastern Oil Shales.

2. Analysis of Sour Water from Processed Eastern Oil Shales.

3. Results of the Environmental Protection Agency (EPA) Extraction Procedure (EP) Toxicity Test.

4. Major and Trace El ments in Product Oil (Metal Analysis).

5. Recovery of Major and Trace Elements from Processed Shales. 


\section{Concentrations in ASTM Water Shake and RCRA Test Extracts.}

\section{Hydroretorting}

1. Leachability of Metals.

Laws. Rules, and Regulations - The laws, rules, and regulations that may apply to the oil shale industry are being synthesized into readily usable format. Since Federal agencies were first to respond with the requested information, these were compiled first. Compilations of Federal laws and regulations pertaining to air and water pollution were prepared during the quarter. The format for the compilation presented below is proposed for inclusion into the Final Report.

\section{Federal Laws - Air}

Two Federal laws applicable to the siting of oil shale production plants are discussed in the following sections. Although these laws are amended from time to time, only their dates of enactment are normally shown when they are referenced. The latest amendments are critical, however, to plant siting. For example, the Clean Air Act has several amendments presently being debated in Congress which, if passed, will be applicable to the siting of a plant. As recently as July 24, 1989, President Bush spoke before Congress on proposed 1989 amendments to the Clean Air Act.

Clean Air Act (1963), P.L. 88-206. The Clean Air Act was enacted in 1963, when Congress authorized the Department of Health, Education, and Welfare to study air pollution. The Act was significantly restructured in 1970 (P.L. 95-95 and P.L. 95-190), posing more stringent levels for ambient air quality and emission levels.

The original purpose of the Act was to restrict emissions of the 7 most common air pollutants: 1) $\mathrm{CO}, 2$ ) hydrocarbons, 3) lead, 4) $\mathrm{NO}_{2}, 5$ ) ozone, 6) particulates, and 7) $\mathrm{SO}_{2}$. The EPA established primary ambient standards to protect human health, and secondary ambient standards with respect to such areas as crop protection and visibility. Among the key elements of the Act that impact the siting of an oil shale processing plant are:

1. Prevention of Significant Deterioration. This element imposes stringent technology-based standards as well as air quality-based emission limitations on new or modified stationary sources. These standards vary with attainment/non-attainment ratings of localities.

2. National Ambient Air Ouality Standards (NAAOS). These are the primary and secondary ambient air standards.

3. National Emission Standards for Hazardous Air Pollutants (NESHAP). Synthetic fuel producers must substantiate the absence of hazardous air pollutants by "process specific" emission filing.

4. National Standards of Performance for New Stationary Sources (NSPS). The NSPS pertains to new or modified stationary sources and is commonly 
established on a case-by-case basis due to the numerous processes for synthetic fuel production.

5. Best Avallable Pollution Control Technology (BACT). All plans for new or modified stationary sources are subject to review to insure that the "best available" technology is used.

6. State Implementation Plans (SIP). Each state must define and implement procedures for attaining and maintaining NAAQS standards. The legislative history of the Act as reported in the Environmental Reporter:

Federal Laws, 1989, is as follows:

Enacted by Public Law (PL) 88-206 in 1963, Amended by PL 89-272 in 1965, Amended by PL 89-675 in 1966, Amended by PL 90-148 in 1967, Amended by PL $91-604$ in 1970, Amended by PL $92-157$ and PL $93-15$ in 1973, Amended by PL 93-319 in 1974, Amended by PL 95-95 in 1977, Amended by PL 95-190 in 1977. Amended by PL 95-623 in 1978, Amended by PL 96-209 in 1980, Amended by PL $96-300$ in 1980, Amended by PL $97-23$ in 1981, Amended by PL $97-$ 375 in 1982, Amended by PL $98-45$ in 1983, Amended by PL $98-213$ in 1983.

\section{Federal Regulations - Air}

While standards are promulgated and administered by the EPA, individual states have the responsibility for attaining and maintaining the standards. The most pertinent regulations set forth are contained in titles 40 and 41 of the Code of Federal Regulations (CFR).

National Environmental Policy Act of 1969 (P.L. 91-190). The National Environmental Policy Act (NEPA) was enacted to require Federal agencies to consider the impact of their actions upon the national environment. This was accomplished under 3 major categories. One was the establishment of the Council on Environmental Quality (CEQ), another requires an annual Environmental Quality Report from the President to Congress, and the third requires Federal agencies to file detailed environmental impact statements (EIS) for proposed activities. These documents must be prepared for major Federal actions "significantly affecting the quality of the human environment" (Section 102[2][C] of P.L. 91-190).

Regarding the impact of NEPA upon the siting of an oil shale production plant, the degree of Federal participation necessary before an EIS would be required, should be considered. Previous legal rulings imply that when Federal agencies issue permits, licenses, certifications, or otherwise regulate private conduct as well as when Federal grants, contracts, and loans have been made to nrivate companies, an EIS should be filed by the appropriate Federal agency. EIS preparation must take place when plant siting is in the developmental stage, hence contributing to the decision-making process. Also, CEQ requires public scoping after the decision to prepare an EIS has been made. Scoping should establish major issues for the EIS. "It shall provide full and fair discussion of significant environmental impacts and shall inform decision makers and the public of the reasonable alternatives which would avoid or minimize adverse impacts or enhance the quality of the human environment." (40 CFR 1502.1) 
The legislative history of the NEPA as reported in the Environmental Reporter: Federal Laws, 1989, is as follows: Enacted by PL 91-190 in 1969, Amended by PL 95-52 in 1975, Amended by PL 94-83 in 1975 .

With few exceptions, all Federal agencies are required to prepare an EIS detailing the environmental impact of an alternative to every proposal for a major Federal action "significantly affecting the quality of the human environment." In addition, many states and localities have passed laws with provisions similar to this requirement. Federal agencies that could be involved in siting an oil shale production plant would include the following:

Departments of Agriculture, Health and Human Services, Interior, Defense, Labor, Transportation, EPA, Nuclear Regulatory Commission, U.S. Army Corps of Engineers, Water Resources Council, Tennessee Valley Authority, and the Interstate Commerce Commission.

Federal-State agencies such as River Basin Commissions of Ohio could be involved as well.

\section{Federal Laws - Water}

The primary Federal laws applicable to the siting of oil shale plants are briefly discussed in the following sections. Although these laws are amended from time to time, only their dates of enactment are normally shown when they are referenced. Their latest amendments are critical, however, to the siting of a plant. For example, the Clean Water Act was enacted in 1977 , and the latest amendments were printed in 1988.

Clean Water Act (1977). The objective of the Clean Water Act (CWA) (originally the Water Pollution Control Act of 1972) is to "restore and maintain the chemical, physical, and biological integrity of the Nation's waters" (Title I PL 92-500). The 1977 amendment altered the focus of the regulating from alkaline and acidic wastes, suspended solids, and other highvolume conventional pollutants, to the stringent control of toxic water pollutants (i.e., heavy metals, pesticides, toxic organic chemicals, etc.). Among the key elements of the Act that impact the siting of an oil shale processing plant are:

The development of effluent treatment minima based on state-ofthe-art technology.

More stringent permitting requirements in areas where necessary to reach water quality standards.

Specific provisions regulating certain toxic discharges.

The legislative history of the Act as reported in the Environmental Reporter: Federal Laws, 1989, is as follows: Enacted by PL $92-500$ in 1972, Amended by PL 93-207 in 1.973, Amended by PL-243 in 1974, Amended by PL 93-592 in 1975, Amended by PL $94-238,94-273$, and $94-558$ in 1976, Amended by PL 95-217 in 1977, Amended by PL $95-576$ in 1978, Amended by PL 96-1.48 in 1979, Amended by PL 96-478, 96-483, 96-510, and 96-561 in 1980, Amended by PL $97-35$ and $97-117$ 
In 1981, Amended by PL 97-164 in 1982, Amended by PL 97-440 in 1983, Amended by PL $100-4$ and 100-202 in 1987, Amended by PL 100-581, 100-653, and 100-688 in 1988 .

\section{Federal Regulations - Water}

Since the EPA and the U.S. Army Corps of Engineers have jurisdiction over different aspects of the Clean Water Act, their responsibilities are reported under each agency heading.

EPA - There are certain regulations. for implementing the Clean water Act and its Amendments that are promulgated and administered by the EPA. The most pertinent regulations set forth deal with water quality planning, management, and standards; hazardous waste designation; the NPDES permit program; and state program requirements. These are all contained under 40 CFR subchapter D. Elsewhere in CFR Chapter 40 are contained regulations for general provisions for effluent guidelines and standards (40 CFR 401) and pretreatment standards (40 CFR 403).

U.S. Army Corps of Engineers - (As Information becomes available, other Federal agencies responsible for implementing various sections of the Clean Water Act will be included).

\section{Task 7. Sample Procurement. Preparation. and Characterization}

The objective of this task is to procure, prepare, and characterize raw and beneficiated Eastern oil shale samples for all of the experimental tasks in this program. Six Eastern shales will be procured and prepared for testing. This task was conducted by MRI .

MRI has completed the acquisition of the bulk samples of shales from the 6 states in the program. The bulk quantity of beneficiated shale has also been prepared and shipped to IGT for processing. The work on this task has been completed.

\section{Task 8. Project Management and Reporting}

The objective of this task is to coordinate all aspects of the program among DOE, IGT, and the various subcontractors to insure that a cohesive program is maintained.

\section{Discussion}

During the quarter, IGT staff visited the Tennessee Technological University (Cookeville) to tour the facilities and to obtain an update on project progress. IGT continued to monitor the progress of the participants and subcontractors working on the program via telephone and written reports. 


\section{FUTURE PLANS}

Work on all the scheduled tasks will continue as planned.

\section{ACKNOWLEDGMENTS}

IGT respectfully acknowledges the significant work being conducted on this project by the individual subcontractors, their principal investigators, and colleagues .-

IIT: Professor D. T. Wasan and Professor D. Gidaspow

OSU: Professor R. M. Pfister

MRI: Dr. C. W. Schultz

TTU: Professor W. P. Bonner

UM: Professor H. S. Fogler

UP: Professor S. $-\mathrm{H}$. Chiang

UN: Professor M. Misra

\section{REFERENCES}

1. Soo, S. L., "Particulates and Continuum," Hemisphere, 1989.

2. Gidaspow, D. and Y. Liu, "Solids Mixing in Fluidized Beds: A Hydrodynamic Approach," Chemical Engineering Science, Vol. 36, No. 3, pp. 539-547, 1981.

3. Rex, Jr., R. C. and William C. S. Hu, "A Comparison of Hydroretorting and Thermal Retorting Facilities for the Shales," Proceedings, 1986 Eastern Oil Shale Symposium.

4. Bunner, W. P., R. B. Bustamante, W. A. Goodwin, and H. W. Leimer, "Environmental Assessment of a Conceptual Hydroretorting Facility for a Tennessee Site," Final Report to IGT 1986 (Data compiled from several sources).

5. Mensinger, M. C., M. J. Roberts, D. M. Rue, and F. S. Lau, "Environmental Data from Moving-Bed Hydroretorting of Three Eastern Oil Shales," Proceedings, 1988 Eastern Oil Shale Symposium.

6. Biezugbe, G. B. O., et al, "Process Off-Gas Characterization Experiments for Block Reactor Runs 10 and 12," DOE/FE/60177-24255, 1986.

7. Agarwal, A. K., "Assessment of Solid Waste Characteristics and Control Technology for 011 Shale Retorting," EPA/600/7-86/019, 1986.

8. Merriam, N. M., C. Y. Cha, and S. Sullivan, "Production of Spent Shales by Simulation of Surface Oil Shale Retorting Processes," DOE/FE/60177$2439,1987$.

9. Hycrude Corporation, "Environmental Analysis of the Eastern Shale Hydroretorting Data Base," DOE-AC20-83LC11039, 1984.

RPP /61090q 8 

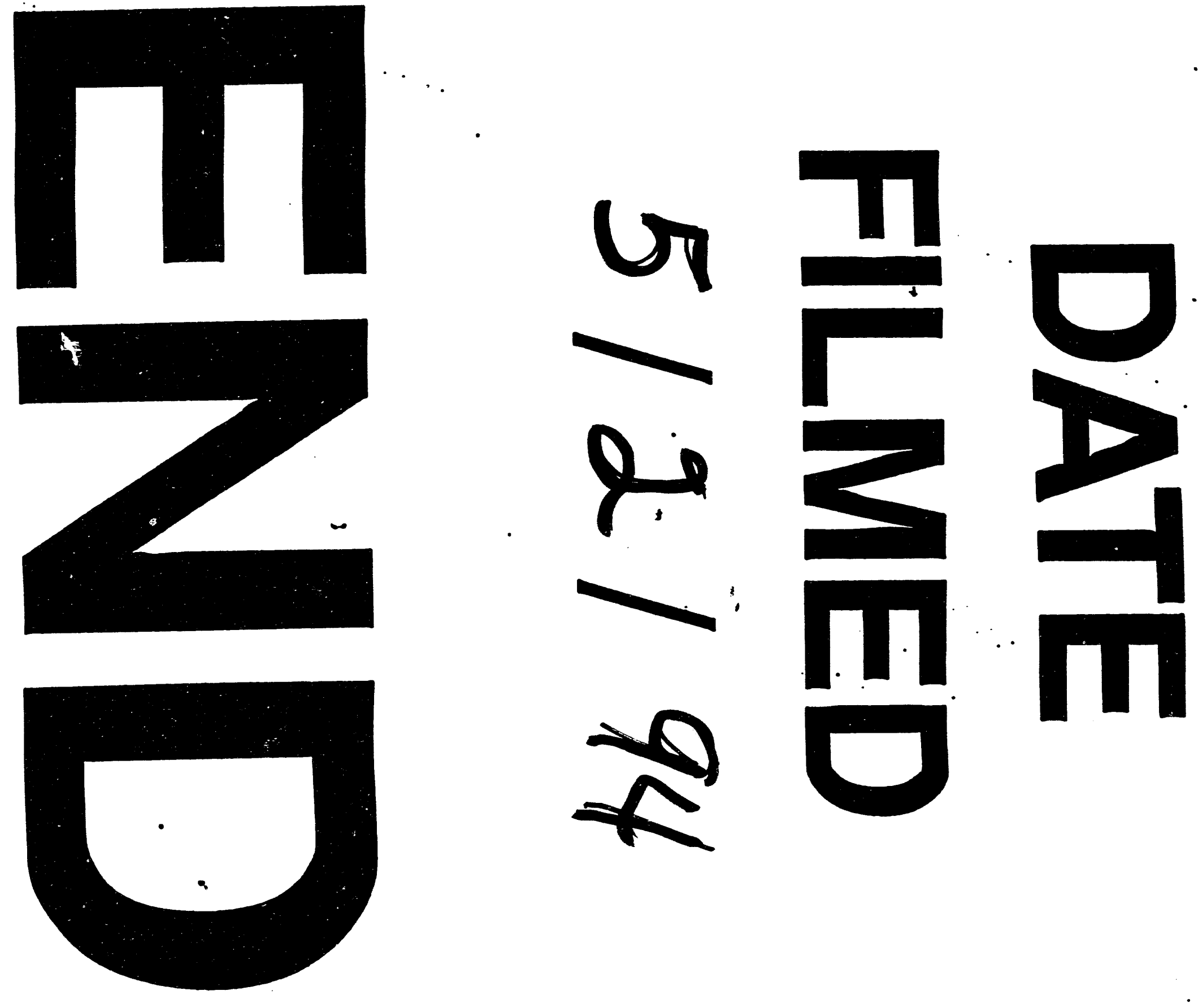